atha daśāvicārādhyāyah | tatra daśāśabdena śubhāśubhaphalapākakāla ucyate | atha pūrvoktaphalānāṃ dinavibhāgajñānaṃ daśājnãnena vinā dụ̣śakam iti daśānayanam avaśyaṃ vaktavyam | yad āha sūryasūriḥ |

yad api sūcitam atra samāphalam tanudhanādigataiḥ khacarais tuyat | dinavibhāgam ṛte na hi gamyate tad aham atra daśānayanaṃ bruve \|

yādavo 'pi |

vividhabhāvaphalotthaphalaṃ khago diśati tad yadanehasi sā daśā| iti tadānayanam nayasammatam paridadāmi vidām saphalaṃ mude \|

atha daśānayanaprakāra ukto varṣatantre |

spaștān salagnān khacarān vidhāya rāsín vinātyalpalavam tu pūrvam | niveśya tasmād adhikādhikāmeśakramād ayam syāt tu daśākramo 'bde \| ūnam viśodhyādhikatạ̣ krameṇāmśāadyam viśuddhāmśakaśeșakaikyam | sarvādhikāmśonmitam eva tat syād anena varșasya mitis tu bhājya śuddhāṃśakāmss tān gunayed anena labdhadhruvāinkena bhaved daśāyāḥ| mānam dinādyam khalu tad grahasya phalāny athāsām nigadet tu śāstrāt ||

1 vicārādhyāyahạ] vicāraḥ K T M \| śubhāśubha] śubhāśubhabha T \| phala] om. B N 2 pūrvokta] pūrvoktānāṃ K T M || phalānāṃ dina] phalādīnāṃ K T M || jñānaṃ] -jānāṃ G 2-3 duhśáakam] durjñeyam K T M 4 tanu] tamu N 8 nayasam-] nayanaṃ B N G \|

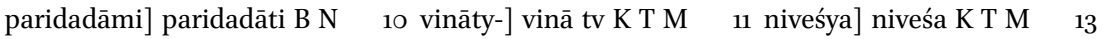
-ādhikāṃśon-] -ādhikoṃśon- N || tat syād] tasyād T; tasmād K

7-8 vividha ... mude] TYS 14.1 10-15 spașțān ... śāstrāt] VT 17.1-3 


\section{The Planetary Periods}

\section{$7 \cdot 1$}

The Periods Based on Deducted Degrees

Now, the chapter on judging the periods. Concerning that, the word 'period' denotes the time of maturation of good and evil results. Now, because it is impossible to know how the results described above are distributed over the days [of the year] without understanding the periods, it is necessary to explain the calculation of periods. As Sūryasūri says [in the Tājikālaṃkāra]:

Although the result of the year, which [arises] from the planets occupying the ascendant, second house, and so forth, has been indicated here, it is not [properly] understood without the distribution of days; hence I describe the calculation of the periods here.

And Yādava [says in Tājikayogasudhānidhi 14.1]:

The time in which a planet gives the results produced by the results of various houses is its period. ${ }^{1}$ Therefore I will give the calculation of those [periods], supported by reason, along with [their] results, for the pleasure of the wise.

Now, the method of calculating the periods is described in Varșatantra [17.13]:

Arranging the true [longitudes of the] planets and ascendant, without the zodiacal signs, entering the one with the fewest degrees first and then [the others] in order of increasing degrees, this will be the order of the periods in a year. Subtracting the lesser from the greater in order, in degrees and so on, the total of the degrees remaining after subtraction will certainly equal the one with the most degrees, and the duration of the year is to be divided by that. One should multiply those degrees [remaining] after subtraction by the constant thus derived: that will be the duration of the period in days and so forth for [each] planet. One should declare the results of these [periods] according to the teaching.

$1 \quad[T]$ he results produced by the results: the tautology is in the original. 
ayam arthạ̣ | daśānayane salagnānāṃ sarvagrahāṇāṃ rāśīn vihāya sarvanyūnāṃśo grahạ pūrvaṃ lekhyạ̣ | punas tasmād yathā yathā yasya yasyāṃsāâdhikyaṃ tathā sa sa grahạ̣ salagno niveśyah | evaṃ niveśitāḥ sarve grahā hīnāṃśasaṃjñakāḥ syuh | varṣe ayaṃ daśākramạ̣ syāt | punar ūnam hīnam aṃsáāyam graham adhikato 'dhikāṃśagrahād viśodhya krameṇa kiṃcid adhikāṃśaṃ tadagrimād viśodhya evaṃ sarve grahāḥ śodhyāḥ | śeșāṃśānāṃ nāma pātyāṃśāḥ śuddhāṃśāś ca | punaḥ pātyāṃśānāṃ yogaḥ kartavyaḥ | sa yogaḥ hīnāṃśasāmyābhāve sarvagrahamadhye yo 'dhikāmśas tattulyam eva syād iti vyāptị̣ ||

nanu hīnāṃśasāmye 'pi tadūrdhvordhvataḥ pātyā ity anenānītapātyāṃśayutih sarvādhikāṃśatulyā bhavaty eveti ||

syād etat | yadi samāṃśāparasya pātyāṃśaśūnyatvaṃ syāt pātyāṃśābhāve daśādyabhāvo 'pi syāt | na ceșțāpattị̣ | daśābhāve tu bhāvamunthāvarṣeśādiphalasyocchedāpatteh | kị̣ ca kṛ́āạnśasāmye samāṃśāparakhagasya daśābhāvo yadi prācīnānām ācāryānām anumatạ syāt tarhi $e k a-$ rāśigānām eko 'ṃśạ̣ harati balı̄ iti jātakoktavad balina ekasyaiva daśā syād ity uktam syāt | aṃśādyasya samatve daśā ca vīryādhikasya pūrvā syāt iti vakșyamāṇahillājavacane nirbalasyānantaram daśety āśayo 'vagamyate | anyathā samāṃśāparakhagadaśābhāvena tatkramākān̉kṣābhāvāt tannirṇāyakaṃ hillājatejaḥsiṃhādivākyam balinạ̣ pūrvā daśā ityādikam unmattapralapitam iva syāt \|

2 yasya] om. G 3 tathā] yathā K || sa sa grahah salagno] sarvagraham lagnaṃ K T; samagrahaḥ lagnaṃ $\mathrm{M} \| \mathrm{sa}^{1}$ ] om. G 4 hīnāṃśa] dīnāṃśa $\mathrm{B} \quad$ 4-5 punar ūnaṃ] punanūnaṃ B N a.c.; punar nūnaṃ N p.c. $\quad 5^{-7}$ aṃśādyam ... śuddhāṃśáśs] aṃśāś N $\quad 5$ adhikato] om. M \|| 'dhikāṃśa] 'dhikāṃśād G K T; adhikāṃśād M 10 nanu] na tu B N \| pātyā ity anenā-] pātyanenā- G 11 sarvādhikāṃśa] sarvādhikāṃśas tat K T M 12 samāṃśāparasya] samāṃśaparakhagasya G; sāmyāṃśāḥ parakhagasya K T M || syāt pātyāṃśā-] syā tyāṃśāG; pātyāṃśā- K T M 13 daśābhāve] daśābhe B N || tu] om. B N 14 phalasyocchedā-] phalasyoddedā- G || samāṃśā-] samāṃśāḥ G 15 prācīnānām] prācīnām B N; prācām G 16 eko 'ṃśaṃ] ekāṃkam B N || jātakoktavad] jātakoktivad K T M || balina ekasyaiva] balinarakasyaiva B N 17 uktaṃ syāt | aṃśādyasya] uttareśādyasya B; uttareṃśādyasya N || samatve] samatvaṃ B N || pūrvā] pūrva B T; pūrvaṃ N 18 vacane] vacano G || daśety āśayo] deśetyāṃśayo B N a.c.; deśe pātyāṃśayo N p.c. || 'vagamyate] vagamyage B 19 khaga] khagasya K T M || kramākāṅkṣā-] kramākṣāṃkṣā- B N || bhāvāt tan] bhāvan na G 2o hillāja] hillājạ̣ B N; hillāje G || vākyaṃ] ca add. B N || pūrvā] pūrva B N 21 pralapitam] pralapitum $\mathrm{M}$

15-16 eka ... balī] BJ 7.3; JP 5.9 
The meaning is as follows: in calculating the periods of all the planets and the ascendant, the planet that has the fewest degrees of all, leaving out the zodiacal signs, should be written down first. ${ }^{2}$ Following that, each planet along with the ascendant should be entered in turn as it has more degrees. All planets entered thus are called 'of reduced degrees'. This will be the order of periods in the year. Thereafter, 'subtracting the lesser', [that is], the planet of fewer degrees and so on, 'from the greater', [that is], from the planet of more degrees in order, [and] subtracting [that planet] of slightly more degrees from the one ahead of that, all planets should be so subtracted. The remaining degrees are called 'deducted degrees' or 'degrees after subtraction'. Thereafter, all the deducted degrees should be added together. Unless [two or more planets have] identical [number of] reduced degrees, that sum will equal [the longitude of] the one that has the most degrees among all the planets: this is a universal rule.

Objection: even if [two or more planets have] identical [numbers of] reduced degrees, they can be deducted one after the other, and the sum of the deducted degrees calculated thus will still equal the [planet] with the most degrees.

That may be; [but] if the latter [planet] with identical degrees should be devoid of deducted degrees, [then] in the absence of deducted degrees there will also be an absence of a period and so forth; and it is not desirable that this should happen, since, in the absence of a period, the result of a house, the munthaha , the ruler of the year and so on could be cancelled. Moreover, when the reduced degrees [of two planets] are identical, if the ancient authorities had approved of the latter planet with identical degrees having no period, then it would have been stated that only the stronger [planet] will have a period, just as it is said in [Brhaj]jātaka [7.3] that 'of several [planets] in a single sign, only the strongest loses its portion.' ${ }^{3}$ And in the statement by Hillāja that will be recounted below - 'If degrees and so on are identical, the period of the stronger [planet] should come first' - it is implicitly understood that the period of the weaker [planet] comes afterwards. Otherwise, since there would be no need for ordering them if the latter planet with identical degrees had no period, the conclusive statements by Hillajja, Tejahsimina and others that the period of the stronger [planet] comes first, and so on, would be like the ravings of madmen.

2 In other words, only longitudes within the respective signs $\left(\right.$ from $0^{\circ}$ to $\left.30^{\circ}\right)$ should be used, not absolute longitudes from the first point of Aries (from $\circ^{\circ}$ to $360^{\circ}$ ).

3 This statement from a pre-Tājika source occurs in the context of longevity calculations, which form the basis for the subsequent calculation of planetary periods for the life as a whole, not within a single year. 
api ca lagnagrahānām așțānām apy aṃśasāmye saptānāṃ pātyāṃśaśūnyatvād ekasyaiva samagravarṣaṃ daśā syāt | na hy ekasyaiva daśāphalaṃ śubham aśubhaṃ vā samagravarṣaṃ bhavatīti bālo 'pi pratipadyate | na cāntardaśādivaśāt phalabheda iti vācyam | pātyāṃśābhāvena tadīyāntardaśāder api gaganakusumāyamānatvāt | ata eva śrimmannīlakanțhadaivajñair ūnam viśodhyādhikataḥ ity uktam | na tu ūrdhvasthagrahaśodhanam adhaḥsthitagrahe uktam \|

atra ūnāṃśagrahe tasmād adhikāṃśebhyah śodhite sati grahāṇāṃ daśādinānāṃ tulyatve 'pi na kāpi kṣatị | tasmād dhīnāṃśasāmyābhāve pātyāṃśayogah sarvādhikāṃśamito bhavati | varṣatantravākye avyayānām anekārthatvād evaśabdo vāśabdavācī jñeyaḥ | hīnāṃśasāmyạ̣ kadācid bhavaty ataḥ śrīmannīlakaṇṭhadaivajñaiḥ pātyāṃśayogaḥ sarvādhikāṃśonmito bhavatīty uktah | anyathā pātyāṃśayogam anuktvaiva lāghavāt sarvādhikāmśair bhājyā ity abhidadhyur ity alam atiprasangena ||

punaḥ pātyāṃśayogena savarṇitena varṣamitị̣ saurī 36o saurasāvanā vā ${ }_{365}{ }^{15}|31| 30$ savarṇitā bhājyā yal labdhaṃ dinādyaṃ sa tasmin varṣe dhruvānikaḥ syāt | anena dhruvāñkena grahāṇāṃ pātyāṃśā gomūtrikāsaṃjñena guṇanaprakāraviśeșeṇa guṇitāḥ șașțyopary upari labdhena yutāḥ santo grahāṇāṃ salagnānāṃ dinaghațīpalarūpāṇi daśāmānāni syụ̣ ||

\footnotetext{
3 bālo 'pi] bālāpi B N $\quad 3-4$ cāntar] cāntara G KT M 4 daśādivaśāt] daśāditi t B; daśādititū N; daśâvidaśā K T M || -bhāvena] -bhavena B || tadīyāntar] taddaśāyām antar K T M 4 4-5 daśāder api] daśepi $\mathrm{N} \quad 6$ ūnaṃ] nūnaṃ $\mathrm{N}$ \| viśodhyādhikatah] viṃśo'dhyā'dhikata M 7 grahe] graho B N 9 daśādinānāṃ] daśādīnāṃ B N || kāpi kṣatị̣] kāpy akṣatiḥ B N; kāpekșatị̣ K || -bhāve] -bhave B 11 evaśabdo] eśaśabdo B N || vāśabdavācī] vācā B N 12-13 -āṃśonmito] -āṃśonmato K; -āṃśānmito T 13 anuktvaiva] scripsi; anuktaiva B N G K T M 14 alam ati] alpamati B N 15 savarṇitena] sarvāṇi nava $\mathrm{K} \mathrm{M}$; sarvāṇi tava T || varșa] varṣasya K T M || sāvanā vā] sāvanādyā T 16 savarṇitā] savarṇitād K T M || bhājyā] bhājyād K T M 17 saṃjñena] saṃgena B N a.c. 18 prakāraviśeșeṇa] prakāreṇa G || yutāḥ] yuktāḥ G; yuktās K T M 19 salagnānāṃ] salalināṃ K; salagneśānāṃ T M || pala] phala G
}

6 ūnam ... ādhikatah] VT 17.2 
Furthermore, if the ascendant and planets, all eight, had identical [numbers of] degrees, then because seven of them would be devoid of deducted degrees, only one would have a period, lasting an entire year. But even a child can understand that the result of the period of a single [planet], whether good or evil, does not last for an entire year. Nor should it be said that there will be a difference in results on account of the subperiods and so on, for in the absence of deducted degrees, the subperiods and so on of that [period] are made [as insubstantial] as flowers in the sky. Therefore, the illustrious Nilakanțha Daivajña said: 'Subtracting the smaller from the greater', rather than saying that [the degrees of] a planet placed ahead should be subtracted from the planet following it.

In this [procedure], when a planet of fewer degrees has been subtracted from those of more degrees than itself, even if the days of the periods of the planets are the same, there is no harm whatever. Therefore, when the reduced degrees [of two or more planets] are not identical, the sum of [all] deducted degrees equals the [planet] with the most degrees. In the statement from the Varșatantra, the word 'certainly' should be understood to mean 'possibly', as indeclinable particles have many meanings. The reduced degrees [of two or more planets] are [only] sometimes identical; therefore the sum of the deducted degrees was said by the illustrious Nilakanța Daivajña to equal the [planet] with the most degrees of all. Otherwise he could have explained more concisely that [the duration of the year] should be divided by the [planet] with the most degrees, without mentioning the sum of the deducted degrees. But enough of digression.

Then the duration of the year, converted [into days] - solar (36o) or civil solar $(365 ; 15,31,30)^{4}$ - should be divided by the converted sum of the deducted degrees: the quotient in days and so on is the constant value for that year. The deducted degrees of the planets, multiplied by this constant through the particular form of multiplication called 'cow's urine'5 and being increased by [converting] whatever exceeds sixty, ${ }^{6}$ will be the durations of the periods of the planets and the ascendant in the form of days, ghațis and palas.

4 That is, a year consisting either of 360 solar 'days', each equalling the passage of the sun through one degree of the ecliptic, or of 365.25875 civil days; cf. section 1.6 above.

5 This method of multiplication, described in Brahmagupta's seventh-century Brāhmasphutasiddhānta and similar to the modern method, takes its name from its zigzag arrangement.

6 That is, converting every 6 o minutes of arc into one degree or every 6 o ghațiss into one day, etc. The phrase will recur many times below. 
atropapattiḥ | tatra hīnāṃśagrahasyādyā daśā | tatrāgamarāvapramāṇaṃ yato vasișthanāradādibhir ādau sampūrṇaphalatoktā | punar daśāvadhijñānārtham ūnam viśodhyādhikataḥ ity uktam | tato daśādinajñānārtham trairāśikadvayam | tad yathā| yadi pātyāṃśayogena varṣadināni labhyante tadaikenāṃśena kim iti | labdham ekāmsśasya dinādiphalaṃ dhruvānkābhidham | punar anyo 'nupātaḥ | yady ekenāṃśenedam dinādiphalaṃ labhyate tadā grahasya pātyāṃśaị̣ kim iti | evaṃ trairāśikena grahāṇāṃ daśādināni syur iti sarvam upapannam |

\begin{tabular}{llll} 
grahāh & hīnāmśāạ & pātyāmśāh & daśādināni \\
\hline budhạ̣ & 21824 & 21824 & 29226 \\
lagnam & 8532 & 63438 & 834427 \\
sūryaḥ & 93659 & 04357 & 91934 \\
śukraḥ & 163626 & 65927 & 89025 \\
bṛhaspatị & 192337 & 24711 & 352834 \\
manjgalạ & 19578 & 03331 & 7644 \\
śaniḥ & 21573 & 15955 & 252646 \\
candrah & 281631 & 61928 & 803122
\end{tabular}

1-8 atropapattị ... upapannam] om. B N K M 9 grahāḥ] om. B || hīnāṃsáḥ] hīnāṃ B || pātyāṃśāḥ] pātyāṃ B || daśādināni] scripsi; daśādi B; gṛhāṇāṃ daśādināni G; daśāmānaṃ dinādikam KT M $102^{1}$ ] scripsi; 34 B G KT M \| 24²] scripsi; 34 B G KTM 11 53] 43 G \| 38] 28 K T M || 44] om. B || 27] scripsi; 28 B G K T M 12 36] scripsi; 44 B G KT M || 43] 51 K T M || 57] 50 K T M || 19] om. B 13 36] 26 K T M || 6] 7 B G || 59] scripsi; 7 B G; 41 K T M || 27] 23 B \| 89 о 25] scripsi; 917 B; 94217 G; 854217 K T M 14 37] 32 K T M \| 47] scripsi; 29 B G; 57 K T M || 11] 6 K T M || 35 28 34] scripsi; 3343 B; 3346 43 G K T M 15 31] 32 G; 36 K T M || 6] om. B 16 1] 5 B || 26] om. B; 16 K $172^{2}$ ] 29 B || 80] oо K T; o M \| $31^{2}$ ] om. B

3 ūnam ... ādhikatah] VT 17.2

9 grahāh] The following table is omitted by N. Other text witnesses give the names of the planets in abbreviated form. \| daśādināni] G gives the figures in this column as a separate table on a different folio. 
This is proved as follows. Concerning the period of the planet with the fewest degrees coming first, there is a roar of evidence from tradition, as Vasiștha, Nārada and others say that [a planet] in the beginning [of a sign] gives full results. ${ }^{7}$ Next, to find out the period boundaries, 'subtracting the lesser from the greater' was declared. Therefore, to find out the [number of] days in a period, [we use] the rule of three twice, as follows: if the sum of the deducted degrees gives the days in a year, then what does one degree give? The quotient of days and so forth for a single degree is called the constant. Then the next proportion: if one degree gives this result in days and so forth, then what do the deducted degrees of a planet give? In this way the days of the periods of the planets are [derived] by the rule of three. Thus all is proved.

\begin{tabular}{llll}
\hline Planet & Reduced degrees & Deducted degrees & Period days \\
\hline Mercury & $2 ; 18,24$ & $2 ; 18,24$ & $29 ; 22,6$ \\
Ascendant & $8 ; 53,2$ & $6 ; 34,38$ & $83 ; 44,27$ \\
Sun & $9 ; 36,59$ & $0 ; 43,57$ & $9 ; 19,34$ \\
Venus & $16 ; 36,26$ & $6 ; 59,27$ & $89 ; 0,25$ \\
Jupiter & $19 ; 23,37$ & $2 ; 47,11$ & $35 ; 28,34$ \\
Mars & $19 ; 57,8$ & $0 ; 33,31$ & $7 ; 6,44$ \\
Saturn & $21 ; 57,3$ & $1 ; 59,55$ & $25 ; 26,46$ \\
Moon & $28 ; 16,31$ & $6 ; 19,28$ & $80 ; 31,22$ \\
\hline
\end{tabular}

7 This is undoubtedly a reference to the stanza quoted below (in section 7.2) from the Nāradasamhitā and the Kaśyapasaṃhitā. I have not been able to locate it in the Vasișțasaṃhitā. Possibly the attribution to Vasișțha rather than Kaśyapa is a mistake: the sentence in which it occurs is present only in text witnesses $\mathrm{G} T$, which often concur and may depend on a common hyparchetype. 
atrodāharaṇam | tatrābdapraveśe 'tisvalpāṃśo budho 'stīti sa prathamato lekhyah | tataḥ kiṃcid adhikāṃśam lagnam | tatah sūryo 'dhikāṃśah | evaṃ sarve sthāpyāḥ | tata ūnāṃśo budhaḥ 2|18|24 adhikāṃśe lagne 8|53|2 viśodhyaḥ śeșaṃ 6|34|38 lagnasyādhạ̣ sthāpyam | evaṃ sarveșāṃ pātyāṃśā jātāḥ | eșāṃ pātyāṃśānāṃ yogaḥ 28|16|31 hīnāmśasāmyābhāvāt sarvādhikāṃśacandrāṃśādinā 28|16|31 tulyo jātah | anena vāradvayaṃ șaștyā savarṇitena 101791 saurī varșamitir 36o vāradvayam șașțaa savarṇitā 1296ooo bhaktā labdho dinaghațīpalātmako dhruvakaḥ 12|43|55 | anena grahānaām pātyāṃśā gomūtrikayā gunitāḥ șaștyopary upari labdhena yutā jātāni grahānāṃ dinādidaśāmānāni | atra prakārāntaraṃ tājikālaṃkāre |

\section{pātyāmśanighnād atha sauravarșād bahvaṃśabhaktād athavā daśāhāḥ \|}

sauravarṣamitir 36o budhapātyāṃśa- 2|18|24 gunā 830|24 sarvādhikāṃśair

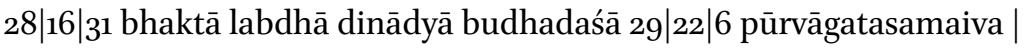

tatra daśāpraveśajñānārthaṃ saurāṇi daśādināni varșapraveśakālīnārke rāśyādau yojyāni | tatsame 'rke daśāpraveśāḥ syuh | udāharaṇam | varṣārambhe sūryah $3|9| 36|59|$ yasmin kāle 'yam sūryah sthitas tasminn eva

1 'ti] om. K T M 2 lekhyah] vilekhya K T; vilekhyas M 324$] 34$ B N a.c. G K M $\|$ adhikāṃśe] adhikāṃśa K; adhikāṃśah T M || lagne] lagnam idam K T M || 8|53|2] 8|53|52 G; $\left.8\right|_{52} \mid 5_{2}^{2} \mathrm{~T} \quad 4$ 38] 28 N p.c. K M $\quad 4-5$ pātyāṃśā jātāḥ] pātyāṃśajātaḥ B N $\quad 5^{-6}$ sarvādhikāmsśa] sarvādhikāṃśaś K T M $\quad 6$ candrāṃśā-] candrośā- K $\quad 7$ 101791] 10|17|91 M \| savarṇitā] savarṇite jātā K T M || 1296ooo] 12|960oo M 8 bhaktā] bhaktāl K T M || 12] 13 B N 9 guṇitāḥ] sangguṇitā KT; saṃguṇitāḥ M 10 dinādi] dināni G \|| tājikālaṃkāre] jātikālaṃkārakare K; jātakālaṃkāre M 11 nighnād atha] nighnā daśa T M \| varșād bahvaṃśa] dvaṃśa B N || bhaktād] bhaktyād B N || bhaktād atha] bhaktā daśa G 12 18] $8 \mathrm{~K} \mathrm{M} \mathrm{||} \mathrm{24}$ 1] 34 B N K M || 830|24] 8|30|24 B N K M; 8|30|34 T 13 31] 3 K M; 13 T 14 saurāṇi] saurādidināni B N || kālīnārke] kālārke K T M ${ }_{16}^{6}{ }_{59}$ ] $5^{11} \mathrm{~N} \|$ yasmin] tasmin K T M || 'yam] om. B N || sūryaḥ ${ }^{2}$ sūryye M

8 The positions given correspond to the morning of 21 July (New Style), $1623 \mathrm{CE}$; cf. note 11 below. As will be seen in section 7.4, the figure is cast for Varanasi, around 7:33 a.m. local apparent time. Although imprecisions in the planetary algorithms employed by Balabhadra complicate matters somewhat, it seems worth noting that a comparison of these sidereal positions with recalculated tropical positions suggests a precessional value (ayanāmśa) closer to $18^{\circ}$ than to the $16^{\circ} 5^{2^{\prime}}$ derived by the method outlined in section 1.9 above. Only the position of Saturn indicates a smaller value (around $15^{\circ}$ ), while the positions of the moon and Mercury differ by $19^{\circ}-22^{\circ}$ from tropical recalculation. Although the subject of the nativity for which the revolution is cast is unknown, it is tempting to suppose it to be Balabhadra himself, who studied under Rāma Daivajña of Varanasi 
An example of this: ${ }^{8}$ in a revolution of the year, Mercury has the fewest degrees; hence it is to be written down first. The ascendant has somewhat more degrees than it, and the sun has more degrees than that. In this way all should be tabulated. Next, Mercury with the fewest degrees at 2;18,24 should be subtracted from the ascendant with more degrees at 8;53,2, and the balance of $6 ; 34,38$ entered under the ascendant. In this way, the deducted degrees of all [the planets] are derived. Because there are no [planets] with identical number of reduced degrees, the sum of these deducted degrees $(28 ; 16,31)$ equals the degrees and so forth of the moon, which has the most degrees of all: $28 ; 16,31$. Dividing the duration of the solar year, twice converted [by multiplication] by sixty [into] 1,296,ooo, by this [sum, also] twice converted [by multiplication] by sixty [into] 101,791, the quotient is a constant of 12;43,55 in days, ghațis and palas. ${ }^{9}$ The deducted degrees of the planets, multiplied by this through the cow's-urine [procedure] and increased by any product exceeding sixty, become the durations of the periods of the planets in days and so forth. Another method for this [is described] in the Tājikālaṃkāra:

Or else, the days of the period [are found] from the solar year, multiplied by the deducted degrees and divided by the great [est] degrees.

Multiplying the duration of a solar year (36o) by Mercury's deducted degrees $(2 ; 18,24)$, [giving] 830;24, and dividing it by the greatest [number of] degrees $(28 ; 16,31)$, the quotient is the period of Mercury in days and so on: $29 ; 22,6$, exactly the same as above.

In connection with this, to find out the commencement of the periods, the solar days of the periods should be added to [the longitude of] the sun at the time of the revolution of the year, in zodiacal signs and so on. When [the longitude of] the sun equals that [result], the periods will commence. An example: at the revolution of the year, the sun was at 3, 9;36,59. ${ }^{10}$ At the

and may well have been born there. Whatever the identity of the subject, this revolution being taken up as an example in a work written more than 25 years later suggests 1623-1624 to have been an important year in his (or, much less probably, her) life. a total of 1,296,00o palas. Similarly, with $60 \times 6$ o seconds of arc to a degree, $28 ; 16,31$ equals 101,791 seconds.

10 That is, the sun had traversed the first three zodiacal signs and was 9;36,59 degrees into the fourth sign, Cancer. 
kāle pūrvoktaprakāreṇānītāsu daśāsu prathamato budhadaśā saury eva jātā dinādyā 29|22|6 | punar varșapraveśakālārke 3|9|36|59 budhadaśāhā 29|22|6 aṃśādau yojitāḥ $4|8| 59 \mid 5$ jāto 'grimadaśāpraveśārkaḥ | evam agre 'pi | athātra varṣaphale saṃkrāntidivasān pañcāngapattre dṛșțā tattaddaśāpraveśam ālakṣya phalāni vācyāni ||

ata eva sāmpradāyikāḥ kasmin kāle daśāpraveśo jāta iti saṃśayya saurasāvanadinādivarṣamānena daśāhāṃś ca samānayanti | tatra daśāpraveśakālajñānārthaṃ varșapraveśavārādau prathamadaśādināni yojyāni upari saptatașṭāni dvitīyadaśāpraveśe vāraghațīpalātmakạ̣ kālo bhavati | punar dvitīyadaśāpraveśakāle dvitīyadaśādināni yojyāni tṛtīyadaśāpraveśakālo bhavati | evam agre 'pi ||

udāharaṇam | śrāvaṇakṛ̣ṇanavamyāṃ śukravāsare sūryodayād gataghațīpaleșu $5 \mid 36$ varșapraveśah | asmin varṣapraveśakāle prathamaṃ budhadaśā jātā saurasāvanadivasādikā 29|47|50 | punar varṣapraveśavāāādau 6|5|36 budhadaśāhā 29|47|50 yojitā 35|53|26 | vārasthāne 35 saptataște śeșaṃ śanivāro jātaḥ | varșapraveśadinād ārabhya ekonatriṃśaddināntaraṃ śanivāre sūryodayād gataghațīpaleșu $53 \mid 26$ dvitīyadaśāpraveśo lagnasya jātạ̣ | punar asmin kāle o| $53 \mid 26$ lagnadaśāhā yojitāḥ pūrvavat tṛtīyadaśāpraveśo vārādyah kālo bhavati | evaṃ sarvatra ||

vāmanena tu munthāphalajñānārthaṃ lagnavan munthādaśāpi kartavyety uktam |

\footnotetext{
1 pūrvokta] pūrva K T M 2 9] $29 \mathrm{~K} \mathrm{~T} \|$ 59] 56 B; $6 \mathrm{~N} \quad 3$ 59] $58 \mathrm{~K} \mathrm{~T} \mathrm{M} \|$ 5] 2 B N 4 phale] phalaṃ B || divasān] divasaṇu B N a.c.; divasaṃ N p.c. || dṛsțțā] dṛsțtyā B N || tattaddaśā] tatra $G \quad 6$ saṃśayya] saṃśaya K; saṃśaye $M \quad 9$ vāra] vama $G \quad 11$ 'pi] om. $G \quad 12$ vāsare] vāre G 14 divasādikā] dinātmikā G K T M \| 50] 5 G $\quad 15$ śeșaṃ] o add. G 16 vāro] vāre B N \|| praveśadinād] praveśā d K; praveśād T M || ārabhya] om. G KT M || ekona] pamca B N 17 26] 6 G; $36 \mathrm{~T} \quad 18$ 26] $36 \mathrm{G} \mathrm{T} \mathrm{\|} \mathrm{praveśo]} \mathrm{praveśe} \mathrm{G} \mathrm{K} \mathrm{T} \mathrm{M} 19$ evạ̣ sarvatra] om. G 20 daśāpi] daśā $G$

9 dvitīya] At this point B N mistakenly repeat: daśāapraveśo jāta iti saṃśayya saurasāvanadinādivarșamānena daśāhāmés ca samānayaṃti tatrāddaśāpraveśakālajñānārthaṃ varșapraveśavārādau prathamadaśādināni yojyāni upari saptataștāni dvit̄̄ya.
}

11 This is clearly a continuation of the example above, where Mercury's period was given as 29;22,6 solar 'days', each corresponding to $1^{\circ}$ of ecliptical motion of the sun, or precisely $1 / 360$ of a year. Using Balabhadra's value of $365.25^{875}$ civil days for the sidereal solar year, each solar day corresponds to $365.25875 / 360$ civil days, making Mercury's period comprise 29;47,50 civil days. Friday, 21 July (New Style), 1623 CE (cf. note 8 above), does indeed correspond to Śrāvaṇa krṣna-navamī, Śaka 1545, in the pürṇimānta calendar system. As Balabhadra elsewhere follows the amānta calendar format prevalent in Bengal, his use of a pürṇimānta date here, similar to his later treatment of Shāh Shujā's nativity (cf. Chapter 8 , note 12), suggests that he was working from a horoscope cast by another astrologer, or by himself prior to relocating to Rajmahal. 
very time when the sun was placed thus, the period of Mercury began, first among the periods calculated by the method described above, [with a duration of] 29;22,6 in solar days and so on. Next, the 29;22,6 days of Mercury's period in degrees and so on, added to [the longitude of] the sun at 3, 9;36,59 at the time of the revolution of the year, gives 4,$8 ; 59,5$ as [the longitude of] the sun at the commencement of the next period, and so with the rest. In an annual prognostication, then, one should look up the days of the [solar] ingresses in an almanac, determine the starting points of the various periods, and declare the results.

Therefore, when followers of tradition wonder at what time a period will begin, they calculate the days of the period by the duration of the year in civil solar days and so on. Then, in order to find out the time when a period begins, the days of the first period are to be added to the day of the week and so forth of the revolution of the year: then, reduced by multiples of seven, this becomes the time of the beginning of the second period in days of the week, ghatis and palas. Again, the days of the second period are to be added to the time of the beginning of the second period: this becomes the time of the beginning of the third period, and so with the rest.

An example: the revolution of the year was on the ninth [lunar day] of the dark [fortnight] in [the month of] Śrāvana, on a Friday at 5 ghațīs 36 palas after sunrise. At this time of the revolution of the year, the period of Mercury came first, comprising 29;47,50 civil solar days and so on. ${ }^{11}$ Next, the days of Mercury's period $\left(29 ; 47,5^{\circ}\right)$, added to the day of the week and so forth of the revolution of the year $(6 ; 5,36),{ }^{12}$ [give] $35 ; 53,26$. The place of the day of the week (35) being reduced by multiples of seven gives Saturday as a remainder. ${ }^{13}$ The beginning of the second period, that of the ascendant, comes after twenty-nine days starting from the day of the revolution of the year, on a Saturday, at 53 ghațis 26 palas after sunrise. Again, the days of the ascendant's period, added to this time $(0 ; 53,26)^{14}$ as before, become the time at which the third period begins, in days of the week and so forth; and so throughout.

But Vāmana says that in order to know the results of the munthahā, the period of the munthaha , too, should be worked out, just like [that of] the ascendant:

12 The first figure (6) refers to the day of the week. As the week begins with Sunday, 6 represents Friday.

13 That is, the number 7.

14 The figure should properly be 7;53,26, the 7 representing Saturday; but as this first place is eventually to be reduced by multiples of 7 , the 7 may be replaced with $o$ at the outset. 
sarvagrahānām munthāyā bhuktāmnśān svāṃś ca piṇdayet || iti |

atha yatra dvayor bahūnāṃ vā grahāṇāṃ aṃśādisāmyaṃ tatra daśākramajñānam uktam hillājena |

aṃśādyasya samatve daśā ca viryādhikasya pūrvā syāt |

vīryasyāpi samatve spaștālpagater daśā pūrvam \|

varșatantre 'pi |

śuddhāmśasāmye balino daśādyā balasya sāmye 'lpagates tu pūrvā || iti |

atra śuddhāṃśānāṃ pātyāṃśānāṃ sāmye adhikabalasya grahasyādyā daśā| naitad yuktam | yato daśākramajñānaṃ hīnāṃśakrameṇoktạ̣ tatra hīnāṃśasāmyābhāve 'pi pātyāṃśasāmyaṃ bhavati | udāharaṇam |

grahāḥ hīnāṃsáạ pātyāṃśạ̣̄

\begin{tabular}{lll} 
candraḥ & 35 & 35 \\
sūryaḥ & 78 & 43 \\
budhạ̣ & 1111 & 43 \\
śukrạ̣ & 1514 & 43 \\
śanị̣ & 1917 & 43 \\
\hline
\end{tabular}

1 bhuktāṃśān svāṃś] bhuktāṃsāâms tāṃś G || piṇḍayet] pịḍayed K T M 2 atha] yatra K T M 5 pūrvam] pūrvā K T M $\quad 7$ iti] om. K T M 8 śuddhāṃsáānām pātyāṃśānāṃ] śuddhāṃśāvāṃ G || balasya] bala K T M 9 yuktam] śuddhāṃśasāmye add. K M || tatra] atra K T M 10 'pi] pātyāṃśasāmyābhāve K T M 11 grahāḥ] om. B T M 12 candraḥ] gu T

7 śuddhāṃśa ... pūrvā] VT 17.4

11 grahāh] The following table is omitted by N. Other text witnesses give the names of the planets in abbreviated form. 
One should add the respective degrees traversed by all the planets and the munthahā. ${ }^{15}$

Next, Hillāja describes how to find the order of the periods when the degrees and so on of two or more planets are identical:

If degrees and so on are identical, the period of the stronger [planet] should come first. If the strength, too, is identical, the period of the [planet] whose true motion is slower comes first.

In Varșatantra [17.4], too, [it is said]:

When the degrees after subtraction are identical, the period of the stronger [planet] comes first, and when the strength is identical, [the period] of the slower [planet] comes first.

Here, [if it is meant that] when the degrees after subtraction, [that is], the deducted degrees, are the same, the period of the planet with the greater strength comes first, [then] this is not correct, because it has been declared that the order of the periods is found from the order of reduced degrees; and even when the reduced degrees are not identical, the deducted degrees can be identical. ${ }^{16}$ An example:

\begin{tabular}{lll}
\hline Planet & Reduced degrees & Deducted degrees \\
\hline Moon & $3 ; 5$ & $3 ; 5$ \\
Sun & $7 ; 8$ & $4 ; 3$ \\
Mercury & $11 ; 11$ & $4 ; 3$ \\
Venus & $15 ; 14$ & $4 ; 3$ \\
Saturn & $19 ; 17$ & $4 ; 3$ \\
\hline
\end{tabular}

15 This appears to be only a partial instruction.

16 This is the closest Balabhadra ever comes to criticizing or disagreeing with Nilakantha Daivajña. In the next paragraph, however, he offers a reinterpretation to save Nīlakantha's face. 
tatra hīnāṃśagrahāḥ pātyāṃśáś ca likhyante | atra sūryabudhaśukrasaurīnāạ pātyāṃśasāmyaṃ yady apy āgatam tathāpi balavicāraṃ vinaiva hīnāṃśakrameṇa budhaśukrāpekṣayā nyūnabalasyāpi raveh pūrvaṃ daśā tato budhasya tatạ śukrasya tatạ śaneh | evaṃ hillājavacanasya svavacanasyāpi vaiyarthyaṃ bhavati | tasmāt śuddhāṃśāḥ rāśiṃ vinā śuddhāḥ yathāvasthitāḥ ye 'ṃśās teșāṃ sāmye ity arthạ̣ | śuddhāṃśānāṃ pātyāṃśānāṃ sāmye iti vyākhyānaṃ devānāmpriyasya sammatam iti |

atha gatisāmye 'pi daśākramajñānam uktam paddhatibhūṣaṇe |

\section{gatisamatve saptasapter vaśāt |}

proktādyair udayakramād atha ca tatsāmye tu pāṭakramāt \|

ayam arthạ̣ | gatisāmye 'pi sūryavaśena prathamoditasya pūrvā daśā tasyāpi sāmye lagnasūryacandrabhaumetyādiprasiddhapāṭhakramād daśā syāt ||

atra lagnagrahayor aṃśasāmye pūrvānītalagnabalagrahabalayor madhye yasyādhikyaṃ tasyādyā daśā | balasāmye lagnasya gatyabhāvāl lagneśagrahayor madhye yasyālpā gatis tasyādyā daśā | uktaṃ ca tājikasāre |

vīrye samāne tanukhețayoś cet syātām tadā lagnapakhețayoś ca | yasyālpabhuktiḥ khalu pūrvako'saujñeyo grahajñair grahapākamārgah || iti|

\footnotetext{
1 hīnāṃśa] hīnāṃśāḥ G; hīnāṃśā K T M \|| śukra] om. G; śukrāṇām K T M $\quad 2$ saurīṇāṃ] saurānāạ G; om. K T M \|| vinaiva] naiva B N 3 raveh] raraveh G 5 vaiyarthyạ̣] vīryārtham B N; vaiparyyam T M 9 saptasapter] sama K M 10 udaya] uda B N \| ca tat] om. B $\mathrm{N} \quad 11$ pūrvā daśā] om. B N 12 lagna] lagnem N $\|$ prasiddha] om. K T M ${ }_{12-15}$ kramād ... sāmye] kramā samye B N 14 atra] atha K T M $\quad 16$ yasyālpā] yasyānya G 18 graha² $^{2}$ iha K T M

9-10 gati ... kramāt] PBh $37 \quad$ 17-18 vīrye ... mārgah] TS 267
} 
Here the planets with reduced degrees and [their] deducted degrees are written. Although the deducted degrees of the sun, Mercury, Venus and Saturn here turn out to be identical, still, in order of reduced degrees, without any consideration of strength, the period of the sun comes first even if it has less strength than Mercury and Venus; then [comes the period] of Mercury, then of Venus, then of Saturn. Thus the statement of Hillajja, as well as [Nilakanțha Daivajña's] own statement, becomes meaningless. Therefore, the meaning is this: 'When the degrees after subtraction, [that is], the degrees that are subtracted, separated, without the zodiacal signs, are identical'. The explanation 'When the degrees after subtraction, [that is], the deducted degrees, are identical' is approved [only] by a fool.

Next, how to find the order of the periods when even the motion is identical is described in Paddhatibhūṣaṇa [37]:

When the motion is identical, by those first declared in order of rising with respect to the sun, and if that, too, is identical, in order of listing.

The meaning is as follows: when the motion, too, is identical, the period of the [planet] first risen with respect to the sun is first. If that, too, is identical, the periods will be in the established order of listing: ascendant, sun, moon, Mars and so forth. ${ }^{17}$

Concerning this, if the ascendant and a planet have [an] identical [number of] degrees, then the period of the one that is superior in the strength of the ascendant and strength of a planet as calculated above comes first. If the strength is equal, then, because the ascendant has no motion, the first period belongs to whichever has the slower motion: the ruler of the ascendant or the [other] planet. And it is said in Tãjikasāra [267]:

If the strengths of the ascendant and the planet should be equal, then, out of the ruler of the ascendant and the [other] planet, the one that has the lesser motion comes first. This should be understood by astrologers to be the [correct] method [of calculating] planetary periods.

17 That is, the order of the days of the week, but with the ascendant placed at the very beginning. 
gater api sāmye uktaval lagneśagrahayor madhye pūrvoditasyādyā daśā | udayasāmye 'pi kathitapāṭhakrameṇa daśākramo jñeya iti | atha māsapraveśe daśānayanam uktạ̣ muktāvalyām |

pātyāṃśayogena bhajed gataișyamāsāntaram syād gunako 'py anena | pātyāmśakāḥ saṃguṇitā daśāh syur uktakramān māsaphale daśānām || hīnāmśakānukramato yathāsthā lavaikyahrnmāsamiteryad āptam| prthak prthak tadgunitāśs ca te 'ṃśā dināni vā māsaphale daśānām || iti |

samarasiṃhena sarvagrahānāṃ bhogyāṃśebhyo daśānayanam uktam |

sarvagrahabhuktāmśān evam saṃsthāpya bhogyabhāgebhyaḥ|

jātānikabhaktavarșe yal labdham tena saṃunayet || pratyekaṃ bhuktāmśáa yo yo yasyāsti rāśisaṃkhyāṅkah| tasyāsti tatpramāṇā divasā ghatyaḥ palāni syụ̂ \|

vyākhyā | sarvagrahāṇām salagnānām bhuktāṃśān karmabhūmau saṃsthāpya amśāa trimśanmadhye śodhitāh santo bhogyāmssāḥ syuh | tebhyah pūrvoktaprakārena yo jāto 'ñkas tena varșaparimāṇam bhājyam \|

1-2 gater ... iti] om.KT 3 uktaṃ] om. BN 4 'py anena] 'tha tena G KTM 6 yathāsthā] yathāstha B K T M; yathāsya N $\|$ miter] mite KM 7 guṇitāś] gaṇitāś B N 9 graha] grahā K T M || bhuktāṃśān evaṃ] bhuktāṃśā nava K M \| saṃsthāpya] sthāpya G 10 bhakta] bha N; bhukta K T M 11 yo yo] scripsi; ye B N; yo G K T M 13 salagnānāṃ] lagnānāṃ B; lagnānā N || bhūmau] bhū B N 13-14 saṃsthāpya] sthāpya B N G 15 jāto 'ńkas] scripsi; jātoṃka B N; jātāṃkas G K T M

4-7 pātyāṃśa ... daśānām] TMṬ 3.14-15 
If the motion, too, is identical, then the first period belongs to whichever rises first as stated [above]: the ruler of the ascendant or the [other] planet. If the rising, too, is identical, then the order of periods is to be found from the order of listing as related.

Next, the calculation of periods in a monthly revolution is described in [Tājika]muktāvali[țippaṇī 3.14-15]:

One should divide the interval of the preceding and following months ${ }^{18}$ by the sum of the deducted degrees: [this] will give the multiplier. The deducted degrees multiplied by this will give the periods according to the order of periods in a monthly revolution stated [above]. Or, those degrees as they are, in order of reduced degrees, multiplied separately by the quotient from dividing the duration of the month by the sum of the degrees, give the days of the periods in a monthly revolution.

[In the Tãjikaśāstra], Samarasiṃha describes the calculation of the periods of all planets from the degrees remaining to be traversed:

Having thus established the degrees traversed by all the planets and divided the year by the figure derived from the degrees remaining to be traversed, one should multiply [the degrees of the planets] by the quotient. For each [planet], whatever number of rāsis [its] traversed degrees [equal], that is its figure: that will be the measure of [its] days, ghațis and palas. ${ }^{19}$

Commentary: ${ }^{20}$ After entering the degrees traversed by all the planets and the ascendant in the place of operations, ${ }^{21}$ [those] degrees being subtracted from thirty will give the degrees remaining to be traversed. The duration of the year is to be divided by the number derived from them by the procedure given above.

18 I take this to mean the interval between the starting points of two consecutive synodic months, i.e., between two consecutive new moons (in the amānta system) or full moons (in the pürnimānta system) - in other words, the duration of one synodic month.

19 The phrasing of these verses is quite convoluted, and the intended method of calculation is not entirely clear to me. In astrological contexts, rāśi normally means 'zodiacal sign'; but as Balabhadra's argumentation below hinges on a different interpretation, I have left the word untranslated here.

20 See Chapter 4, note 10.

21 Presumably a piece of ground or similar prepared for writing. 
ayam arthaḥ | pūrvaṃ grahabhāgā hīnāṃśakrameṇa sthāpitāḥ | idānīṃ te bhāgās trimśanmadhye śodhitāḥ santo bhogyabhāgā vaiparītyena hīnāṃśā jātāḥ | te punar vaiparītyakrameṇa pātyāṃśāḥ kartavyāḥ | teșāṃ yogena varșaṃ bhajet | yal labdham tena yasya yasya grahasya yo yo rāśisaṃkhyāno 'ṃśasaṃghasaṃkhyāñko 'sti tattadgrahāṃśarūpāḥ pratyekaṃ bhuktāṃśāḥ idānīṃ pātyāṃśavaśena sthāpitāḥ tān saṃguṇayet | guṇane kṛte sati tattatpramāṇās tattadgrahāṃśavaśena daśā divasādyāḥ syuh | udāharaṇam |

\section{grahāḥ hīnāṃsáạ bhogyāṃsāḥ pātyāṃsáḥ̣ daśādināni}

\begin{tabular}{lllll}
\hline bṛhaspatị & 30 & 2700 & 520 & 71640 \\
śanih & 820 & 2140 & 310 & 421320 \\
mańgalah & 1130 & 1830 & 40 & 53200 \\
lagnam & 1530 & 1430 & 210 & 285320 \\
budhạ & 1740 & 1220 & 510 & 685320 \\
sukraḥ & 2250 & 710 & 40 & 53200 \\
candrah & 2650 & 310 & 210 & 285320 \\
sūryah & 290 & 10 & 10 & 13200 \\
\hline
\end{tabular}

tatra hīnāṃsaādyā grahāḥ | eșāṃ bhogyāṃśānāṃ vaiparītyakrameṇa śodhane pātyāṃśāḥ syuḥ | pātyāṃśānāṃ yogah 27 anena varṣasaṃkhyā saurī 36o bhaktā labdho dinādidhruvakaḥ ${ }_{13} \mid 20$ | anena grahāṇām pātyāṃśā gunitā jātāḥ saurā daśādivasāḥ | ayaṃ daśākramaḥ samarasiṃhenāpracaradavastho 'bhihitạ ||

1 pūrvaṃ] pūrvaḥ G 2 bhāgā] bhāga B; bhāva N 3 punar] om. B N 4 yasya ${ }^{1}$ ] om. B N \| grahasya] om. B K M \| yo ${ }^{1}$ om. B N 5 grahāṃśa] gṛhāṃśa K T || rūpāḥ] svarūpāḥ B N K T M $\quad$ 5-6 bhuktāṃśāḥ idānīṃ] bhuktāṃśāridānīm K T 6 pātyāṃśavaśena] pātyāṃśakavasena K T; pātyāṃśakavaśena M \| saṃgunayet] guṇayeta G; guṇayet K T M \| guṇane] guṇena B N $\quad 6-7$ tattat] tat B N; tata G 7 pramānāās] pramāṇāt K T M $\|$ tat $^{1}$ ] om. G \| tattad] tad G \| vaśena] vato G p.c.; vaśato KT M 8 grahāḥ] om. B \| hīnāṃśāḥ] yogah 36o B || dināni] dinādi K T M 9 o] 10 B; 20 G 10 8] 4 G || 42] 43 B || 13] 24 K T M || 20] 22 B N $113^{1}$ ] $\left.20 \mathrm{~B} \mathrm{~N} \| \mathrm{O}^{1}\right] 15 \mathrm{~T} \mathrm{M} \|$ 2O] 30 T M 12 10] scripsi; 1 B N G; 20 K T M \| 28] 20 K T M || 53] 43 B N 13 40] 50 K T M || 201] 10 K T M || 10] o K T M || 53] 43 B N 14 53] 57 B N 1520 o M $\quad 161^{2}$ ] 10 B N 17 grahāḥ] atraiva cakranyāsạ̣ add. K T M \| eșāṃ] șāṃ N 19 bhaktā] bhaktāl K T \| dinādidhruvakaḥ] dināni dhruvaḥ G 20 saurā] saurī B N; saura K T M \|| -pracarad] -pracurad K T M

8 grahāh] The following table is omitted by N. Other text witnesses give the names of the planets in abbreviated form. 
The meaning is as follows: previously, the degrees of the planets were entered in the order of reduced degrees. Now, those degrees, being subtracted from thirty, become the degrees remaining to be traversed, [that is], the reverse of the reduced degrees. Next, they should be made into deducted degrees in reverse order, and one should divide the year by the sum of those [deducted degrees]. Using that quotient, one should multiply whatever numerical figure of rāsis, [that is], the numerical figure of accumulated degrees, that any planet has in the form of the degrees of that planet: the separate traversed degrees now entered in the form of deducted degrees. When the multiplication has been performed, the periods corresponding to the degrees of the respective planets will be of that duration in days and so on. An example:

\begin{tabular}{lllll}
\hline Planet & $\begin{array}{l}\text { Reduced } \\
\text { degrees }\end{array}$ & $\begin{array}{l}\text { Remaining } \\
\text { degrees }\end{array}$ & $\begin{array}{l}\text { Deducted } \\
\text { degrees }\end{array}$ & Period days \\
\hline Jupiter & $3 ; 0$ & $27 ; 0$ & $5 ; 20$ & $71 ; 6,40$ \\
Saturn & $8 ; 20$ & $21 ; 40$ & $3 ; 10$ & $42 ; 13,20$ \\
Mars & $11 ; 30$ & $18 ; 30$ & $4 ; 0$ & $53 ; 20,0$ \\
Ascendant & $15 ; 30$ & $14 ; 30$ & $2 ; 10$ & $28 ; 53,20$ \\
Mercury & $17 ; 40$ & $12 ; 20$ & $5 ; 10$ & $68 ; 53,20$ \\
Venus & $22 ; 50$ & $7 ; 10$ & $4 ; 0$ & $53 ; 20,0$ \\
Moon & $26 ; 50$ & $3 ; 10$ & $2 ; 10$ & $28 ; 53,20$ \\
Sun & $29 ; 0$ & $1 ; 0$ & $1 ; 0$ & $13 ; 20,0$ \\
\hline
\end{tabular}

Here are the planets in reduced degrees and so forth. Subtracting the degrees remaining to be traversed by them in reverse order will give the deducted degrees. The sum of the deducted degrees is 27 ; the solar measure of the year (360) divided by this gives a constant of 13;20 in days and so on. The deducted degrees of the planets multiplied by this [constant] give the solar days of their [respective] periods. This order of periods, set forth by Samarasiṃha [in the Täjikaśāstra], is not in current use. ${ }^{22}$

22 Or, possibly but less likely: 'This order of periods is declared by Samarasimha not to be in current use.' 
atra kecit sarvagrahabhuktāṃśakarāśín ālokya yo bhaved alpạ̣ iti samarasiṃhavākye rāśiśabdasya saṃghavācitve vaktavye sarvagrahabhuktāmśakasaṃgham hy älokya yo bhaved alpaḥ ity evam samarasiṃho brūyāt | tan noktam ato rāśipadopādānasāmarthyād rāśyādigrahāṇāṃ salagnānāṃ daśā prāguktavidhinā vidheyety āhuh | katham | meșādirāśișu prathamato 'lparāśigo graho lekhyah | tatas tadadhiko graho lekhyah | evam uttaratrādhikādhikarāśisthāḥ salagnāḥ sarve grahā lekhyāḥ | tataḥ pūrvapūrvo graho rāśyādir agrimāgrimagrahāt śodhyaḥ | evaṃ sarve 'pi śodhyāḥ | teșāṃ rāśyādiyogasyāṃśān vidhāya tair varșamānam bhājyam | yal labdhaṃ sa dinādidhruvakaḥ syāt | tena salagnagrahāṇāṃ kṛtāṃśānām aṃśādi guṇanīyam | 10 yad bhavati sā dinādikā daśā syāt ||

udāharaṇam | pātyarāśigrahānā̄m yogo rāśyādiḥ 1o|o|o | anenāṃśíkṛtena 300 sauravarșamitir 36o bhaktā labdhaṃ dinādidhruvakaḥ 1|12 | anena śodhitā grahā aṃsíkṛtā guṇitā jātāḥ sarveșāṃ daśādivasāḥ ||

\begin{tabular}{lllll} 
grahāh & hīnarāśayah & pātyarāśayạ̣ & daśādināni \\
\hline candraḥ & 1151410 & 1151410 & 54170 \\
lagnam & 2254050 & 1102640 & 48320 \\
sūryah & 3102540 & 0144450 & 174148 \\
budhạ & 424820 & 0222240 & 265112 \\
sukrah & 4183030 & 0154210 & 185036
\end{tabular}

\footnotetext{
1 bhuktāṃśaka] bhuktāṃśa B G || rāśīn] rādhīn K || iti] ity eva K T M $\quad 2-3$ bhuktāṃśaka] bhuktāṃśa K T M 3 ālokya] avalokya K T M || alpah] iti add. G || samarasiṃho] samarasiṃha G 3-4 tan noktam] tatroktam B N K T M 4 padopādāna-] padopādānā- B N \| grahāṇāṃ] grahāṃ B N 5 prathamato] prathamatā G $\quad 6-7$-ādhikādhika] -ādhika G K

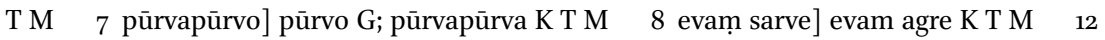
pātyarāśi] pātyamśášsi K 13 dinādi] dināvi $G \quad 15$ hīnarāśayah] hīnarāśayo grahāḥ G || pātyarāśayaḥ] pātyarāśayo grahāḥ G || daśādināni] daśādinādi 36o K T M $161^{2}$ ] 4 G || $10^{2}$ ] 20 K T \|| 5417 o] scripsi; 4510 oo G; 4510 o K T M 18 10] 1 G || 25] 24 G \| 48] 46 K T M 1948 ] $40 \mathrm{~K} \|$ 51] 50 K $\quad 2018^{1}$ ] $10 \mathrm{~K} \mathrm{~T} \mathrm{M}$
}

15 grahāh] The following table is omitted by B N. Other text witnesses give the names of the planets in abbreviated form. 


\subsection{Including or Excluding the Signs: Different Opinions}

Concerning this, some say that if the word rāśi in Samarasiṃha's statement [in the Täjikaśāstra] beginning 'Examining the rāśis [and/of] the degrees traversed by all the planets, the one that is the smallest'23 had been meant to denote 'accumulation', then Samarasimha would have said, 'Examining the accumulation of the degrees traversed by all the planets, the one that is the smallest'. This was not said, and therefore, as the word rāsi is capable of signifying it, a period should be worked out by the method described above from [the longitudes of] the planets and ascendant in zodiacal signs and so on. How? Beginning [the counting of] the signs from Aries, the planet occupying the least sign is to be written down first; next, the planet greater than that should be written down: thus all the planets and the ascendant should be written down as they occupy the other signs in increasing order. Then, [the longitude of] each preceding planet should be subtracted from each following planet, in signs and so on. Thus all are to be subtracted. When the degrees of the sum of these [subtracted longitudes] in signs and so on have been worked out, the duration of the year should be divided by them: the quotient will be the constant in days and so on. [The subtracted longitudes of] the planets and ascendant having been converted to degrees, [those] degrees and so on should be multiplied by that [constant]. The result will be the period in days and so on.

An example: the sum of the planets in deducted signs is 10, o; o. The solar duration of the year (360), divided by this [value] converted to degrees (300) gives a constant of 1;12 in days and so on. [The longitudes of] the planets after subtraction, converted to degrees and multiplied by this [constant], give the period days of all [the planets]:

\section{Planet $\quad$ Reduced signs ${ }^{24}$ Deducted signs Period days}

$\begin{array}{llll}\text { Moon } & 1,15 ; 14,10 & 1,15 ; 14,10 & 54 ; 17,0 \\ \text { Ascendant } & 2,25 ; 40,50 & 1,10 ; 26,40 & 48 ; 32,0 \\ \text { Sun } & 3,10 ; 25,40 & 0,14 ; 44,50 & 17 ; 41,48 \\ \text { Mercury } & 4,2 ; 48,20 & 0,22 ; 22,40 & 26 ; 51,12 \\ \text { Venus } & 4,18 ; 30,30 & 0,15 ; 42,10 & 18 ; 50,36\end{array}$

23 This statement by Samarasimpha has not been quoted above.

24 This phrase, apparently used in analogy with 'reduced degrees', is meaningless: as the signs are now included, the longitudes given are in no way 'reduced' (hìna). 
(cont.)

\begin{tabular}{llll}
\hline grahāh & hīnarāśayaḥ & pātyarāśayaḥ & daśādināni \\
\hline bṛhaspatiḥ̣ & 682545 & 1195515 & 595418 \\
śanih & 8255055 & 2172510 & 925412 \\
mañgalah & 100 o o & 1495 & 405854 \\
\hline
\end{tabular}

yādavena tu rāśyādigrahāṇāṃ daśā prakārāntareṇoktā|

lagnādirișphāntagatagraheșu

yo 'lpo bhapūrvo hi khagah sa cādau|

sthāpyo 'dhiko 'smād adhikas tato 'gre

caivam kramāl lagnamukhān vilikhya \|

lagnam cāgrakhagāt tyajet tadanu taccheșo vilagnād adhaḥ

sthāpyas tam vihagam tadagrakhagataḥ śeșas tu pūrvād adhaḥ|

evam sarvakhagān viśodhya ca tataḥ samsthāpayet pūrvaval

lagnāt sarvakhagādhikam tu vivaram sarvādhikādho likhet \|

śuddhāmsśayogena bhajec ca varșam

labdhena lagnādikhagādharasthān |

śuddhāmśakān samguñayed daśā syāt

prthak prthag vyomasadām dinādyā $\|$

dvau vā trayaś cet samarāśikhețās tadalpabhāgaḥ prathamo vidheyaḥ|

samānabhāge 'lpakalas tu liptātulye 'Ipavego hi gatau samāyām |

pūrvodito yo 'tha vilagnakhețau samau tadā lagnadaśaiva pūrvā || iti |

3 19] 18 K; 29 T M || 59] scripsi; 58 G K T M 4 8] 88 K || 251] 15 K T M || 2] 1 G || 10] 11 T || 92] 52 M 5 54] scripsi; 44 G K T M; yogah 10 oo oo oo pātyarāśīnāṃ yogah 36o add. G 7 riṣphāntagata] riḥphāta G 9 'smād] smakīyam B; smārka | yaṃ N; syād K T M 9-766.8 adhikas ... svakīyam] om. B N 9 tato 'gre] tataś G 11 taccheṣo] tacchreyo K T M 12 taṃ] tad K T 17 śuddhāṃśakān] śuddhāṃśakāt K T M 19 vidheyaḥ] nidheyaḥ K T M 20 bhāge] bhāgo K T M \|| 'lpakalas] scripsi;'lpakales G; lpaphalais K T M \| vego hi] vegas tu K T M || samāyām] samāyāt K M 21 pūrvodito] pūrvotkṣato G; pūrvādito T

7-21 lagnādi ... pūrvā] TYS 14.3-7

20 'lpakalas] The emendation is supported by MS TYS1. 
(cont.)

\begin{tabular}{llll}
\hline Planet & Reduced signs & Deducted signs & Period days \\
\hline Jupiter & 6,$8 ; 25,45$ & 1,$19 ; 55,15$ & $59 ; 54,18$ \\
Saturn & 8,$25 ; 50,55$ & 2,$17 ; 25,10$ & $92 ; 54,12$ \\
Mars & 10,$0 ; 0,0$ & 1,$4 ; 9,5$ & $40 ; 58,54$ \\
\hline
\end{tabular}

But [in Tãjikayogasudhānidhi 14.3-7], Yādava describes the periods of the planets in signs and so on by a different method:

Among the planets occupying [the houses] beginning with the ascendant and ending with the twelfth house, the planet that is the least [removed from the ascendant] in signs and so on is to be set down first; next, the one greater [in distance] than that and the one greater than that. After writing them down in [this] order, beginning with the ascendant, one should subtract the ascendant from the planet ahead; then the remainder should be set down beneath the ascendant. [Then one should subtract] that planet from the planet ahead of it; the remainder [should be set down] beneath the former [planet]. Subtracting all planets in this way, one should set them down as before; but beneath the [planet] with the greatest [distance] of all one should write the difference remaining after all the planets [listed] from the ascendant.

One should divide the year by the sum of the remaining degrees and multiply the remaining degrees, [written] beneath the ascendant and each planet, by the quotient: this will give the individual periods of the planets in days and so on. If two or three planets are in the same sign, the one with the fewest degrees should be set down first; if the degree is the same, [the one] with the fewest minutes; if the minute is the same, the one with least velocity; if the motion is the same, the first one to rise. If the ascendant and a planet are the same, then the period of the ascendant comes first. 
udāharaṇam | tatra lagnādikrameṇa sarve grahāḥ śodhitagrahāś ca likhyante | atra sarvakhagādhikaṃ vivaraṃ rāśyādi 2|24|39|45 sarvabhāvaprānte vartamānasya candrasyādhastāl likhitam | athaișāṃ śuddhānāṃ yogo rāśyādiḥ 13|14|23|25 eșām aṃśāḥ 404|23|25 | anena sauraṃ varșamānaṃ 36o bhaktam labdho dinādidhruvakaḥ o|53|24|50 | anena grahānām antarāṇy aṃśādīni gunitāni jātā daśāhāḥ saurāḥ ||

athāntardaśāprakāra uktas tatraiva |

śuddhāṃśayogena bhajet svakīyam daśādinādyaṃ ca phalena hanyāt | śuddhāṃśakān svān nijataḥ krameṇa cāntardaśābhyo vidaśāpi caivam ||

rāśyādigrahaśuddhāṃśayogena |

grahāḥ lagnādivyayaparyantagạ̣̄ yogāḥ daśādināni

\begin{tabular}{llll}
\hline lagnam & $225405^{\circ}$ & $014445^{\circ}$ & 13742 \\
sūryah & 3102540 & 0222240 & 195517 \\
budhah & 424820 & 0154210 & 135844 \\
śukrạ̣ & 4183030 & 1195515 & 442627 \\
brhhaspatih & 682545 & 2172510 & 685516 \\
śanih & 8255055 & 1495 & 30249
\end{tabular}

2 45] 55 K T M 4 404] 40|4 M || 23|25²] 235 T || anena] om. K T M || sauraṃ] sāre K; saura M 5 o] om. G || 24] scripsi; 4o G K T M \| grahānām antarāṇy aṃśādīni] grahāṇām antararāśyādīni K; grahāṇām mantararāśyādīni T M $\quad 7$ athā-] atrā- K T 8 bhajet] bhavet K T M || svakīyaṃ] svarka | yaṃ N || phalena] balena M 9 -āṃśakān] -āṃśakāṃ B N T; -āṃśakāṃs K T || svān nijataḥ] svānijataḥ B; svāmiṃ nijataḥ N; tān nijatạ̣ K M \|| daśābhyo] daśātho G KTM || vidaśāpi] vidiśādi G; videśāpi K $\quad$ 9-10 caivam || rāśyādi] om. G 11 grahāḥ] om. B || lagnādivyayaparyantagāḥ] scripsi; vidaśānāṃ grahāṇāṃ li B; lagnādityayaparyantagāḥ K; lagnādityaparyantagāḥ T M || yogāḥ] yoga 13142325 B || daśādināni] scripsi; yogah 36o B; yogādaśādinādi 36o K T M 12 o 1444 50] scripsi; oo 1449 5o B; o 15 o o K T M \| 13742 ] scripsi; 131210 B T M; $231210 \mathrm{~K} \quad 1325]$ 30 B || о 2222 40] scripsi; oо 221740 B; o 27 7 30 K T M || 1955 17] scripsi; 19 50 50 B K T M 14 42] 32 K T M || 13] 12 M 15 44] 54 M

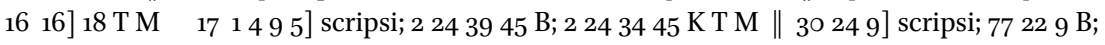
$72229 \mathrm{~K} \mathrm{~T} \mathrm{M}$

8-9 śuddhāṃśa ... caivam] TYS 14.8

11 grahāh] The following table is omitted by N G. Other text witnesses give the names of the planets in abbreviated form. 
An example, as follows: all the planets, and [the differences between] the planets after subtraction, are written in order, beginning with the ascendant. Here, the difference remaining after all the planets $-2,24 ; 39,45$ in signs and so on - is written beneath the moon, which is placed in the last of all the houses [occupied]. Next, the sum of these [differences] after subtraction is 13,$14 ; 23,25$ in signs and so on; their [value in] degrees is $404 ; 23,25$. The duration of the year in solar [days] (360) divided by this gives a constant of $0 ; 53,24,50$ in days and so on. The differences between the planets in degrees and so on, multiplied by this [constant], give the solar days of their periods. ${ }^{25}$

Next, the method of [calculating] subperiods is described in the same place [Tājikayogasudhānidhi 14.8]:

One should divide the days and so on of [a planet's] own period by the sum of the degrees after subtraction and multiply [each planet's] own degrees after subtraction by the result in order from [the period ruler] itself. A third-level period [is derived] from the subperiods in the same manner.

According to the sum of the degrees of the planets after subtraction, including the signs: ${ }^{26}$

\section{Planet Positions from the ascendant Sum $^{27} \quad$ Period days up to the twelfth house}

$\begin{array}{llll}\text { Ascendant } & 2,25 ; 40,50 & 0,14 ; 44,50 & 13 ; 7,42 \\ \text { Sun } & 3,10 ; 25,40 & 0,22 ; 22,40 & 19 ; 55,17 \\ \text { Mercury } & 4,2 ; 48,20 & 0,15 ; 42,10 & 13 ; 58,44 \\ \text { Venus } & 4,18 ; 30,30 & 1,19 ; 55,15 & 44 ; 26,27 \\ \text { Jupiter } & 6,8 ; 25,45 & 2,17 ; 25,10 & 68 ; 55,16 \\ \text { Saturn } & 8,25 ; 50,55 & 1,4 ; 9,5 & 30 ; 24,9\end{array}$

25 These calculations are not clear to me. Measuring the ecliptical distance from the ascendant to the first following planet, from there to the next, and so on up to the ascendant again, the sum of all eight distances can only be $360^{\circ}$, giving a constant of 1 solar day or $0 ; 59,8,10$ civil days (using Balabhadra's value for the duration of the sidereal year).

26 This phrase does not seem to be connected with the rest of the text. It may or may not be intended to accompany the following table.

27 Properly speaking, these are not sums but differences or distances. 
(cont.)

\begin{tabular}{|c|c|c|c|}
\hline grahāh & lagnādivyayaparyantagāḥ & yogāḥ & daśādināni \\
\hline mañgalah & 10000 & 3151410 & 93414 \\
\hline candrah & 1151410 & 2243945 & 75229 \\
\hline
\end{tabular}

atha hīnāṃśakramadaśādūṣaṇam āha sa eva |

pūrvālpabhuktāmsśakamārgato 'tra daśākramo yaị̣ samavādi vipraiḥ | nābodhi tair yāvanasampradāyo na cintitā vāpi phalārthayuktị̣ \| tathā hi yo 'lpāmsśakhago 'ntyago 'sya pūrvā daśā tatphaladā katham syāt | antyā tathāingasthitabhūribhāgakhețasya citreyam ato hi heyā $\|$

atra lagnasyaiva sarvāpekṣayā mukhyatvāt tatsamīpavartino grahasyādyā 10 daśā dūravartinạ̣ paścād iti sadyuktikavicārābhāvād dhīnāṃśamārgadaśāvaśyaṃ tyājyeti yādavoktị̣ | nanu yādavoktadaśāsādhane kiṃ mūlam | pūrvoktasamarasiṃhavākye rāśiśabdopādānāt samarasiṃhavākyam eva mūlam iti cen na | yato rāśiśabdo meșādirāśivācakạ̣ saṃghavācakaś ca | dvau rāśi puñjameșādyau ity amarasiṃhokteh | atra rāśiśabdaḥ samgha-

3 10 o o o] 112030 40 B || 315 14 10] scripsi; 12453 50 B M; 13453 50 K; 10 o o o T || 93414 ] scripsi; $495^{2} 14$ B; $485^{2} 15$ K T M 41151410$] 1152430$ B || 2243945$] 13242325$ K T M \| 7522 9] scripsi; 751549 B; 752549 K T M $\quad 5$ dūṣaṇam] kramam B N 6 bhuktāṃ́aka] bhuktyaṃśaka K 7 nābodhi] nabodhi K T M || vāpi] cāpi K T M 8 phaladā] phaladāṃdā N 9 antyā] om. B N; aṃtyāt K T \| tathānga] tathāgra K M \| citreyam] tritriyam B N || heyā] deyā B 10 lagnasyaiva] lpatasyaiva B N $\quad 11$ sadyuktika] sayuktika K T M $\quad 12$ daśā ... yādavokta] om. B N || nanu] na tu K M || sādhane] sāvane K M 13 vākye ... samarasiṃha ${ }^{2}$ ] om. B N 14 cen na] om. K T 15 meșādyau ity amara] meșādyāciṃtyamara K \| amarasiṃhokteh] amarāsihokter G

6-9 pūrvālpa ... heyā] TYS 14.9-10 15 dvau ... meșādyau] AK 3.214 
(cont.)

\begin{tabular}{llll} 
Planet & $\begin{array}{l}\text { Positions from the ascendant } \\
\text { up to the twelfth house }\end{array}$ & Sum & Period days \\
\hline Mars & 10,$0 ; 0,0$ & 3,$15 ; 14,10$ & $93 ; 41,4$ \\
Moon & 1,$15 ; 14,10$ & 2,$24 ; 39,45$ & $75 ; 22,9^{28}$
\end{tabular}

Next, the same [author] finds fault with the order of periods according to reduced degrees ${ }^{29}$ [in Täjikayogasudhānidhi 14.9-10]:

The Brahmans who approve this order of periods, where the [planet] with the least number of traversed degrees comes first, have not understood the Yavana tradition, nor have they considered the reasons behind the [predicted] results. For how could the period of a planet with few degrees, occupying the twelfth house, give its results first, and that of a planet with many degrees, occupying the ascendant, [do so] last? This [kind of period] is strange, and thus to be rejected.

Here Yādava is saying that, due to the absence of well-founded considerations such as the ascendant being the foremost of all [the houses], and the period of a planet placed near it therefore coming first, [while the period] of one placed far away comes later, the periods according to [the order of] reduced degrees must be rejected. ${ }^{30}$ But what is the foundation of the calculation of periods described by Yãdava? If [it is said] that, because the statement by Samarasimha cited above contains the word rāśi, Samarasiṃha's statement itself is the foundation, then [we say] no, because the word rāśi denotes both the zodiacal signs beginning with Aries and an accumulation, according to the statement by Amarasiṃha [in Amarakośa 3.214]: ‘There are

28 Ecliptical longitudes in this table have been adjusted to agree with the preceding table, and derived values recalculated where required for internal consistency. The penultimate figure in the bottom row has, however, been preserved to agree with the figure given in the running text above, despite its unknown derivation.

29 Or 'in order from [the planet with] the fewest degrees'.

30 The actual basis of Yãdavasūri's objection is almost certainly that the period of a planet should be activated by the progressive motion of the ascendant through the signs reaching that planet. Balabhadra's offered interpretation thus confirms Yādavasūri's charge against Brahman authors of not understanding the intentions of Arabiclanguage astrologers. 
vācī sampannaḥ | katham | aṃśakaśabdo hy atra rāśitriṃśadbhāgavācako 'sti | rāśiśabdasya meșādivācakatve saty api aṃśātmakatvāt teșāṃ rāśīnāṃ pṛthag aṃśaśabdopādānaṃ vyarthaṃ syāt | ata eva sarvagrahabhuktāṃśān evam samsthāpya iti padyadvayena samarasiṃhena bhogyabhāgebhya eva daśānayanaṃ svīyaṃ matāntareṇābhyadhāyi na bhogyarāśibhya iti ||

amum evābhiprāyam manasy abhidhāya samarasiṃhābhiprāyajñais tejaḥsiṃhavāmanādibhị̣ sākṣād aṃśādigrahaṇam evākāri | kaiścid rāśityāgo 'pi | tad yathā | tejaḥsiṃhaḥ |

spaștāmśáāinn saptakhețān salagnān

kṛtvāmiśádyam bhuktam ādāya teșām |

yo 'lpāmśa ạ syāt taddaśāmśáa tu pūrvam

sthāphyās tasmād apy adho yo 'dhikāṃśạ̣ || iti |

vāmano'pi |

bhuktabhāgādikāḥ khețāḥ kartaryā lagnasaṃyutāḥ || iti |

muktāvalyām api |

nyūnāṃśasya daśādimā tadanu bahvaṃśasya ceti kramāt | iti |

\footnotetext{
1 śabdo hy atra rāśi] śabdas K T M $\quad{ }^{1-3} 3$ śabdo ... aṃśa] om. B $\quad 1$ bhāga] bhāva K M $\quad 2$ vācakatve] vācakatvo $G \quad 4$ evaṃ saṃsthāpya iti] eva sthāpyeti $G \|$ padya] pakșa $B \quad 5$ svīyam] s scripsi; svīya B N G K T M 6 -prāyajñais] -dhāyajñais B $\quad 7$ sākṣād aṃśādi] sākṣādi B || grahaṇam evākāri] grahaṇam evākārih B; grahaṇavākāri G 9 spașțāṃśādīn] spaștāṃśādan B 11 'lpāṃśaḥ] lpāṃ K || taddaśāṃśās] scripsi; tatadaṃśās B; tattadaṃśās G T; taddaśāyās K M 12 apy adho yo 'dhikāṃśaḥ] apy ādau py adhikāṃśạ̣ B; atha dhothodhikāṃśa G a.c.; atha dhothāṃdhikāṃśa $\mathrm{G}$ p.c.; apy adho yādhikāṃśa K 14 bhāgādikāḥ] bhogyādikāḥ B 16 daśādimā] daśādinā K T M
}

9-12 spașṭā- ... -āṃśah] DA $29.1 \quad 16$ nyūnā- ... kramāt] TM 8o

1-774.8 -vācī ... 'nye-] Folios $187^{\mathrm{r}}$ and $188^{\mathrm{v}}$ are missing from N. 
two [words] rāśi: a multitude and [the signs] beginning with Aries.' Here, it is appropriate for the word rāśi to denote an accumulation. Why? Because here, the word 'degree' denotes a thirtieth-part of a rāśi; 31 and if the word rāśi should denote [the signs] beginning with Aries, then because those signs consist of degrees, including the word 'degree' separately would be pointless. ${ }^{32}$ Therefore, in the two verses beginning 'Having thus established the degrees traversed by all the planets', Samarasimha set forth his own calculation of periods according to another school of thought, from the mere degrees remaining to be traversed [by the planets] and not from the signs to be traversed. ${ }^{33}$

It was with this intention in mind that Tejahsiṃha, Vāmana and others who understood the intention of Samarasimpha so evidently accepted only [the use of] degrees and so on, and some [explicitly] rejected [the use of] signs, as follows. Tejaḥsiṃha [says in Daivajñālaṃkrti 29.1]:

Establishing [the places of] the seven planets and the ascendant in exact degrees and so forth and taking their traversed degrees and so on, the degrees of the period of the one that has the fewest degrees should be set down first, and beneath that, [the period degrees of] the one that has more degees.

And Vāmana [says]:

The planets should be established in traversed degrees and so on, together with the ascendant.

And in [Tājika]muktāvali [8o it is said]:

The period of [the planet] with the fewest degrees comes first, and then [the period] of one with more degrees, in that order.

31 Strictly speaking, the word used in the quotation from Samarasiṃha is amśa rather than the formally diminutive amiśaka used here, but this is of little consequence: both words mean 'part' generally and, in astronomical-astrological contexts, often 'degree' in the sense of $1 / 360$ of the circle.

32 This is pure sophistry: as Balabhadra was no doubt well aware, the words rāśi and aṃśa are frequently used together in the sense of 'sign' and 'degree', respectively, in contexts similar to the lines quoted from Samarasimha above.

33 One may well ask what 'his own calculation [...] according to another school of thought' could mean. As the larger context of the quotation from Samarasimpha is, unfortunately, not available to us, his precise views must for the present remain unknown. 
tājikabhūṣaṇe 'pi |

ādau hinalavas tato 'dhikalavas tasmād analpāṃśakah | iti |

tājikasāre 'pi |

sāngeșu khețeșu lavādināyo hīnas tadaṃśān prathamaṃ vilikhya | iti |

tājikālaṃkāre 'pi |

$\bar{a} d \bar{a} v$ alpalavas tato 'dhikalavah $\mid$ iti |

tājikatilake 'pi |

spașțikrtāngayutasaptadivaukasāṃ yo

bhāgādinā laghutarạ̣ kila taddaśädau | iti |

grahajñābharaṇe 'pi |

salagnasaptagrahahīnabhuktabhāgān vilikhya prathamaṃ ca | iti |

tājikaratnamālāyām api |

salagnasūryādișu khecareșu yo 'lpāmśáakah sa prathamaṃ nidheyaḥ| iti |

ityādi bahūni vacāṃsi rāśirāhityapratipādakāni santi | yādavena tu kiṃ mūlam an̉gīkṛtya rāśyādigrahadaśānayanam abhāṇi tad abhiprāyaṃ vayaṃ na jānīmah ||

3 'pi] om. T M 4 lavādinā yo] lavādinātho T M || tadaṃśān] tadeśān M 8-11 divaukasāṃ ... sapta] om. B 13 salagna] yo lagna B || 'lpāṃśakaḥ sa] lpāṃśakāmśaḥ̣ B || nidheyaḥ] vidheya K T M 15 vayaṃ] om. G 16 jānīmaḥ] jānīyu G

2 ādau ... āmpśakah] TBh 12.2 4 sāngeșu ... vilikhya] TS 262 
And in Tājikabhūṣaṇa [12.2 it is said]:

First [the planet] with the fewest degrees, then the one with more degrees, then one with many degrees.

And in Täjikasāra [262 it is said]:

Writing down first the degrees of the one least in degrees and so on among the planets and the ascendant ...

And in the Tãjikālaṃkāra [it is said]:

First [the planet] with the fewest degrees, then the one with more degrees.

And in the Täjikatilaka [it is said]:

Of the exactly established [places of the] seven planets together with the ascendant, the period of the one that is least in degrees and so on comes first.

And in the Grahajñābharạ̣a [it is said]:

And writing down first the degrees of the one least in traversed degrees among the seven planets and the ascendant ...

And in the Täjikaratnamāla [it is said]:

Among the ascendant and the planets beginning with the sun, the one that has the fewest degrees is to be set down first.

There are many such voices upholding the exclusion of the zodiacal signs. ${ }^{34}$ But on the authority of whose opinion Yādava declared the calculation of periods from [the positions of] the planets in signs and so on - that we do not know.

34 But in fact, none of the quotations just given by Balabhadra explicitly excludes the signs, thus leaving it an open question whether some or all of these authors were speaking of absolute longitudes reckoned from Aries. 
atha ca tathā hi ityādipadyena tvayā yā yuktir uktā sāpi cintyā $\mid$ na hi vācanike 'rthe yuktiḥ prabhavet | pūrvoktavākyeșu svalpāmsśagrahakrameṇa daśānayanābhidhānāt | atha ca lagnādityoḍuānām adhikabalavatạ̣ syād daśādyā tato 'nyā iti jātakapaddhatau śrīpatyukter lagnāt dvādaśasthasya sūryācandramasor anyatarasya balișthasyādau daśā phaladā bhaven na veti saṃdehah kasyāpi manasi na jāgarti tarām | tadvad yatkiṃcidbhāvastho graho 'lpāṃśạ̣ śubham aśubhaṃ svaphalaṃ dātuṃ samartha eva ||

nanu hīnāṃśādigrahānāām ādyā daśoktā tato 'nyeșām iti | tatrālpāṃśānāṃ kathaṃ prathamatạ phaladātṛ̂tvam ||

ucyate |

\section{ādau sampūrṇaphaladam madhye madhyaphalapradam | ante tucchaphalam lagnam sarvasminn evam eva hil|}

iti nāradakaśyapokteh sarvasmin g̣̣he bhāve ca yathā yathā rāśisamīpavartyamśasthitatvaṃ bhavati tathā tathā mahat phaladātṛtvam asti | yathā yathāṃśopacayas tathā tathā phaladātṛtvam api prāggrahāpekṣayā kiṃcin nyūnam iti yuktih \|

evaṃ jīrṇatājikaśāstramūlabhūtaṃ hīnāṃśakrameṇa daśānayanam | śrīmannīlakaṇthadaivajñair navīnatājikakartṛbhiś coktam | etat spaștam uktaṃ muktāvalyām |

\footnotetext{
1 padyena] padyeta B || tvayā yā] tv apāpā B; tvayā K M || yuktir] bhuktir G || sāpi] syāpi B; sā K 4 daśādyā] daśāghā $M \|$ jātaka] tājaka $B \quad 5$ sūryācandramasor] sūryoccaṃdramasor G || veti] vā add. B G 7 svaphalaṃ] svakalaṃ G 8 nanu] na tu B || grahāṇām ādyā ] bhādyā B 9 kathaṃ] om. M 11 phalapradam] phadaṃ G a.c.; phaladạ̣ G p.c. 12 tuccha] dușța $G$ \| phalaṃ] phaladaṃ $G \quad 13$ nāradakaśyapokteḥ] om. B N \| gṛhe] grahe $G$ K T M \| bhāve] bhāvi N \| yathā²] om. B G 13-14 samīpavartyamśa] samīpatyamıśa B N; samīpavartyeśa $\mathrm{G} \quad 14$ mahat] mahā M 15 -āṃśopacayas] -āṃśoyayas B N \| tathā²] om. B N; tuccha add. K T M $\|$ api] asti K T M 17 tājika] tājake B 19 uktaṃ] om. K T M
}

1 tathā hi] TYS 14.10 3-4 lagnā- ... 'nyā] JKP 7.8 $11-12$ ādau ... hi] KS 22.20; NP 1.56.305; NS 14.18

35 Balabhadra is now addressing either Yādavasūri himself or an imaginary opponent favouring his opinion. 
Moreover, the argument you put forth in the verse beginning 'For how could' should be considered, ${ }^{35}$ since no argument based on an actual statement can be found - [as seen] from the description, in the quotations given above, of calculating the periods in the order [beginning with] the planet with the fewest degrees. And when, in Jätaka[karma]paddhati [7.8], Srīpati states:

Of the ascendant, sun and moon, the period of whichever is the strongest will be first, then the next ...

- no doubt whatever arises in anyone's mind about whether or not the period of the sun or moon, whichever is stronger, [even if] occupying the twelfth [house] from the ascendant, can give its results first. Likewise, whatever house a planet of few degrees occupies, it is certainly able to give its own result, [whether] good [or] evil.

Objection: the periods of planets with fewer degrees and so on are said to come first, and then [those] of others, but how do [planets] with fewer degrees come to give their results first?

[In reply] it is said [in Kaśyapasaṃhitā 22.20, Nāradapurāṇa 1.56.305, and Nāradasaṃhitā 14.18]:

In the beginning [of a sign], the ascendant gives full results; in the middle, it gives middling results; at the end, its results are trifling: it is the same everywhere.

According to this statement by Nārada and Kaśyapa, in every sign and house, the ability to give results is proportionately greater the closer a degree is to [the beginning of] the sign. As the degrees increase, the ability to give results likewise diminishes somewhat as compared to planets [placed] earlier: this is the reason.

Thus the calculation of periods in the order of reduced degrees is founded on the doctrine of the ancient Tajikas; and it is also described by the modern Tājika author, the illustrious Nillakaṇțha Daivajña. ${ }^{36}$ This is clearly stated in [Täjika]muktāvali[țippaṇi 3.37]:

$36 \quad$ As always when referring to Nilakanthha, Balabhadra uses the respectful plural. In this instance, however, the plural makes an alternative translation possible (if less likely): 'by the illustrious Nīlakanțha Daivajña and the modern Tājika authors'. The phrase could also be taken to mean 'by the illustrious Nīlakanțha Daivajña, author of the modern Tājika [school]' 
rāśyādihīnakramato grahādeḥ kecid vadanty ādhunikā daśāhān | rāśin apāsyeti purātanoktīr amanyamānās tu durāgraheña \|

ity alam atiprasanggena | anyeșām api matāny āhur abhiyuktās tukajyotirvidah |

vihīnarāśikramaśo daśāhān yathāsthitarkșair jagur ittham eke |

kecit tu yuktāyanabhāgakebhyo rāśyādikebhyas tv apare 'ṃśakebhyạ || yat khattakhuttavarakhindakaromakädyā

mlecchās tathā ca krtinaḥ smarasiṃhapūrvāḥ |

rāsín apāsya jagur alpalavād daśādyam

tad bhādigasya khacarasya balādhikatvāt $\|$ iti |

atha grahāṇāṃ tāsīradaśā muktāvalyām |

ye varșamāsadinalagnanirīkșakāḥ syus

te tatra tanmitadaśāpatayo na cānye |

àdyā daśädhikadrśaś ca tatas tadūnasy-

eti krameṇa vidușaḥ pravadanti varșe \|

prthak prthag drșțikalädikena varșādisaṃkhyādyumukham nihanyāt |

bhajed drgaikyena ca tanmitena labdham daśāhā dyuphale tu nādyaḥ ||

1 grahādeh] g̣̣hādeḥ K || ādhunikā] ādhvanikā K T M $\quad 2$ apāsyeti] apaśyeti B N 3 abhiyuktās] abhiyuktānas $\mathrm{G} \|$ tuka] tu K M $\quad 5^{-6}$ eke | kecit] ekecit B N T $\quad 6$ bhāgakebhyo] bhāmakebhyo M $\quad 7$ vara] om. B N $\|$ khindaka] khindhika K T M 8 kṛtinah] kṛtins B N \|| smarasiṃha] samarasiṃha B N 9 lavād daśādyaṃ] lavād vaśādyaṃ K 10 bhādi] bhāti G 13 tanmita] tatra hi B N 14 dṛśaś] daśáś K T M 16 pṛthak pṛthag] pṛthaka G; șțhathak șțhathak N $\|$ dyumukham]] yumukhaṃ B N $\quad$ 17-778.1 ca ... krameṇa] om. B N 17 tanmitena] scripsi; tanmatena G K T M \| dyuphale tu] dyuphalena K T M

1-2 rāśyādi ... durāgraheṇa] TMṬ 3.37 $\quad 5^{-6}$ vihīna ... 'ṃśakebhyaḥ] TMṬ 3.40 $\quad$ 7-10 yat ... balādhikatvāt] TMṬ $3.39 \quad$ 12-17 ye ... nāḍyah] TMṬ 3·35-36 
Some moderns obstinately proclaim the days of the periods to be in order from the planet and so on with the fewest zodiacal signs and so on, from the beginning of a house, not considering the statements of the ancients beginning with 'Discarding the zodiacal signs'.

But enough of digression. The diligent Tuka Jyotirvid gives the opinions of others as well [in Täjikamuktāvalițippaṇi 3.40, 39]:

Some declare the days of the periods in order without the zodiacal signs, with reference to the true asterisms; others from the degrees with precession added to them; yet others, from the degrees including the zodiacal signs.

What Khattakhutta, the great Khindika, Romaka and other foreigners said, and likewise Smarasiṃha and other wise men - [reckoning] the period from the [planet] with the fewest degrees and so on, 'discarding the zodiacal signs' - is due to the superior strength of a planet occupying the beginning of a zodiacal sign.

\subsection{Three Varieties of $t a \bar{s} s \bar{r} r a$ Periods}

Next, the tāsira periods of the planets [are described] in [Täjika]muktāvali[țippaṇi 3.35-36]:

Those [planets] which aspect the ascendant of the year, month or day are the rulers of the periods extending for those [times], and no others. The first period is of [the planet with] the strongest aspect, and then [follows the period] of [the one with] the lesser [aspect]: in this order do the learned proclaim [the periods] in a year. One should multiply the number of days and so on in the year by the points and so on of each aspect separately and divide them by the sum of the aspects contained in that [astrological figure]. The quotient is the [number of] days in the period; in [a figure cast for] the results of a day, nādīs. ${ }^{37}$ 
atra lagnanirīkṣakā grahā hīnāmésakrameṇa daśāpradāh syuḥ iti tājikasāroktir na yuktisahā | yatas tāsīradaśā dṛștịmūlabhūtā dṛșțirahitasyālpāṃśakhețasya sabalasyāpi daśābhāvāt ||

udāharaṇam | varșalagnanirīkṣakāḥ sūryendubudhaguruśanayaḥ santi | teșām dụșțị kalādikā sū 50 cam 40 bu 30 bṛ 20 śa 10 | varṣasaṃkhyā saurī 36o svasvadṛṣtyā gunitā dṛstỵaikyena 15o bhaktā labdhā daśāhāḥ sū 120 cam 96 bu 72 bṛ 48 śa 24 | anenaiva krameṇa sūryādīnāṃ varṣe daśāḥ syuh ||

atha māsalagnanirikkșakāḥ sūryabhaumaśukracandrāḥ | teșāṃ dṛștị kalādikā sū 40 maṃ 25 śu 15 caṃ 10 | atra māsasaṃkhyā 30 | anenaiva krameṇa svasvadṛsțtyā gunitā dṛsțtyaikyena go bhaktā labdhā māsadaśāhāḥ sū 13|2o mam $8 \mid 20$ śu 5 |o cam $3|20| \mid$

evaṃ dinapraveśalagnanirīkṣakāś candraguruśukraśanibhaumāḥ | teșāṃ dṛștị̣ kalādikā caṃ 45 bṛ 30 śu 20 śa 15 maṃ 10 | dinapraveśayor antarālaghaṭikāḥ 6o kalpitāḥ svasvadṛsțyā guṇitā dṛgaikyena 120 bhaktā labdhā daśâghațikāḥ caṃ $22 \mid 30$ bṛ 15 śu 10 śa $7 \mid 30$ maṃ 5 || atha bhāvatasīradaśā tatraiva |

śodhyà lagnādayo bhāvāh svīyasvīyāgryabhāvatah | prthak prthak ca śeșāmśās te kalpyā divasāh kramāt \| lagnādīnām athaiteșām saurasāvanatoktavat | ayạ̣ daśākramo bhāvadaśākramaṇikābhidhah \|

2 na] om. B N || yatas] yas tu B N 3 sabalasyāpi] sabalāpi B N 5 bu] tu K \| bṛ] śu K M; gu T 6 dṛsțyāa dṛsáa G \| 150] om. K T M \| bhaktā] bhaktāl M 7 bu] budha K T M \| bṛ] śu K M; gu T || sūryādīnāṃ] om. B N || varșe daśāḥ] varșeśāḥ G 8-10 dṛ̣̦tịh ... guṇitā] om. B N 9 40] 4 K T M || 25] 15 G || śu] śukra K T M \| 15 caṃ] om. G \| caṃ] caṃdra T M 9-10 anenaiva ... krameṇa] om. G 10 dṛsțtyaikyena] dṛștikyena N; dṛstyaikona M \| bhaktā] bhaktāl M $\quad{ }_{11} 5 \mid$ o] 5 |10 K T M || 3|20] 3|21 K T M $\quad 12-13$ dina ... 10] om. B N 13 śa 15] om. G 14 6o] $6 \mathrm{G} \|$ drgaikyena] dṛțtyaikyena K T M 15 caṃ] campura $G$ \| śa 7 |3o maṃ 5] śa 7 maṃ 3o K T M $\|$ 5] om. G 17 svīyāgrya] svīyāpra- K M 18 kalpyā] kalpā B N KM 20 kramaṇikā-] karmaṇikā- B

17-20 śodhyā ... -bhidhaḥ] TMṬ 3.27-28 
The statement of the Täjikasāra on this matter - 'The planets aspecting the ascendant give their periods in order of reduced degrees' 38 - is not wellreasoned, for tāsīra periods are founded on aspects, because a planet of few degrees, even if strong, will have no period if it does not have an aspect. ${ }^{39}$

An example: the sun, the moon, Mercury, Jupiter and Saturn aspect the ascendant of the year. Their aspects in points and so on are: $\mathrm{su}[\mathrm{n}] 5^{\circ}$, mo[on] 40, Me[rcury] 30, Ju[piter] 20, Sa[turn] 10. The number of the solar [days in a] year (360), multiplied by each aspect and divided by the sum of the aspects (150), gives the days of the periods: $\mathrm{su}[\mathrm{n}]$ 120, mo[on] 96, Me[rcury] 72 , Ju[piter] 48, Sa[turn] 24. The periods of the sun and others in the year will be in this very order.

Next, the sun, Mars, Venus and the moon aspect the ascendant of the month. Their aspects in points and so on are: $\mathrm{su}[\mathrm{n}] 40, \mathrm{Ma}[\mathrm{rs}] 25, \mathrm{Ve}[\mathrm{nus}]$ 15, mo[on] 10. Here, the number of the [days in a] month (30), multiplied by each aspect in this very order and divided by the sum of the aspects (9o), gives the days of the periods in the month: $\mathrm{su}[\mathrm{n}] 13 ; 20, \mathrm{Ma}[\mathrm{rs}] 8 ; 2 \mathrm{O}, \mathrm{Ve}[\mathrm{nus}]$ 5; $\mathrm{O}, \mathrm{mo}[\mathrm{on}] 3 ; 2 \mathrm{O}$.

Similarly, the moon, Jupiter, Venus, Saturn and Mars aspect the ascendant at the revolution of the day. Their aspects in points and so on are: mo[on] 45, Ju[piter] 30, Ve[nus] 20, Sa[turn] 15, Ma[rs] 10. The interval between two daily revolutions considered as 60 ghațis, multiplied by each aspect and divided by the sum of the aspects (120), gives the ghațis of the periods: $\mathrm{mo}[\mathrm{on}]$ 22;30, Ju[piter] 15, Ve[nus] 10, Sa[turn] 7;30, Ma[rs] 5 .

Next, the täsira periods of the houses [are described] in the same place [Tājikamuktāvalititippaṇī 3.27-28]:

The houses beginning with the ascendant are to be subtracted each from the following house, and the remaining degrees of each to be considered as days in order. Then these [houses] beginning with the ascendant are [converted into] civil solar [days] as [previously] described. This order of periods is called the progressive periods of the houses.

38 This quotation, unmetrical if intended as an $\bar{a} r y \bar{a}$ half-stanza, is not attested by available independent witnesses of the Tãjikasāra (which typically employs syllabic rather than moraic metres) and is likely to be a misattribution. Possibly Balabhadra had in mind Tajjikasāra 348 on broadly the same topic.

39 But Balabhadra is, perhaps deliberately, missing the point: the quoted half-stanza explicitly speaks of the internal order only of the planets aspecting the ascendant, not of all the planets. 
atha prakārāntaras tatraivoktaḥ |

evaṃ bhāvāntarāmśāa te prthak ca triṃśatā hatāḥ|

svasvodayoddhṛtā labdham syus tasīradaśāh kramāt \|

dinādyā lagnapūrvāṇām svasvāmiphaladāyakāh |

saurasāvanatā cāsām prakartavyā niruktavat \|

atra bhāvasvāmināṃ balena śubham aśubham vā daśāphalaṃ bhāvadaśādineșu vācyam | tatrāpi dvirāśisvāmināṃ grahāṇāṃ phalạ̣ punar āvartate | tatrāpi grahayogena mitraśatrurūpekșaṇena kiṃcid vilakṣaṇaṃ phalam vācyam | eșām saurasāvanārtham anupātaḥ | yadi māsasauradinaiḥ zo māsasaurasāvanadināni 30|26|17|37|3o labhyante tadā tattadbhāvasauradivasaị̣ kānīti | evaṃ māsasaurasāvanadināni bhāvasaurāhair guṇyāni triṃśatā bhājyāni labdhā daśāyāḥ saurasāvanāhāḥ syur iti ||

atha bhāvatasīradaśāyāṃ prakārāntareṇa viśeșas tatraivoktah |

vyayasaṃdhyūnalagnāṃśās te syur bhuktāṃśakās tanoḥ|

lagnonalagnasaṃdhyamśāas te tu bhogyāhvayāh smrtāḥ \|

lagnasaṃdhivihīnā ye saṃdhyamśās te 'rthabhāvajāhn|

anyatrāpy evam evāmeśāḥ sādhyāh sakalabhāvajāh \|

saurasāvanatām caișām vidhāyoktavidhānatah |

ayaṃ daśākramo yad vā bhāvodbhavakramābhidhaḥ\|

tatra lagnaisyabhāgotthadaśādyā kìrtitā tanoh |

20

tadbhuktabhāgadinajā rișphānte syāt punas tanoḥ \|

\begin{abstract}
1 atha] atra K || -āntaras] -āntaram M || -oktaḥ] -oktam M 2 ca triṃśatā] scripsi; triṃśatā $300 \mathrm{~B}$; ; triṃśatāḥ $300 \mathrm{G}$; trizoośatā K T M 3 svodayoddhṛtā] svodayo hṛtā M $\quad 5$ sāvanatā] sāvanato K; sāvanataś T M || cāsāṃ] vāsāṃ B N 6 śubham aśubhaṃ] śubhạ̣ śubhama G 6-7 daśādineșu] daśādișu K M $\quad$ 7-9 tatrāpi ... vācyam] om. K T 9 eșāṃ] evaṃ KTM 10 17|37|30] 17|30 N; 37|30 G; 10|37|10 KTM \| tattad] tad B N 11 bhāvasaurāhair guṇyāni] bhāvasaurā ṇyā B N 13 -āntareṇa] -āntareṇaiva KT M \| viśeșas tatraivoktaḥ] viśeșa traivoktaḥ K 15 saṃdhyaṃśās] śodhyāṃśās M || bhogyāhvayāḥ] bhomyāhvayās K 16 vihīnā ye] vihīnārthaṃ G; vihīnārtha K T M 17 anyatrāpy evam] avatrāpyem B N; paratrāpy evam G K T M \| sakala] saphala T M 18 sāvanatāṃ] scripsi; sāvanātta B N; sāvanatā G; sāvanato K T M || caișāṃ] vaiṣāṃ K T M 19 bhāvodbhava] bhaved bhāva G KT M 21 tadbhukta] tadukta K T M || bhāga] bhāva K T M
\end{abstract}

2-5 evaṃ ... niruktavat] TMṬ 3.29-3o 14-21 vyaya ... tanoḥ] TMṬ 3.31-34

2 ca triṃśatā] The emendation, required by the metre, is supported by MS TM1. 
Then another method is described in the same place [Täjikamuktāvalițippanī 3.29-30]:

Thus, too, the intervals in degrees between the houses are each multiplied by thirty and divided by the oblique ascensions of each [sign]: the quotients will be the tāsira periods in order, in days and so on, of the ascendant and other [houses], each giving the results of its ruler. They too should be converted into civil solar [days] as [previously] explained.

Here, the good or evil results of periods are to be predicted for the days of the periods of the houses according to the strength of the rulers of the houses. Therefore, the results of those planets which rule two signs will repeat; but due to [different] planets occupying [the signs] and due to [different] aspects of friendly or inimical nature, somewhat different results are still to be predicted. In order to [convert] these [periods] into civil solar [days], a proportion [is applied]: if the 30 solar days of a month yield $30 ; 26,17,37,30$, then what [number do] the solar days of this or that house [yield]? Thus, the civil solar days of a month are to be multiplied by the solar days of a house and divided by thirty; the quotient will be the civil solar days of a period.

Next, a special rule for [calculating] the tāsìra periods of the houses by another method is described in the same place [Täjikamuktāvalițippaṇi $3_{31-}$ 34]:

The degrees of the ascendant less by its junction with the twelfth house are the degrees traversed by the ascendant, while the degrees of the junction [following] the ascendant less by the ascendant [itself] are called [its degrees] yet to be traversed. The degrees of the [next] junction less by [the degrees of] the junction [following] the ascendant belong to the second house. The degrees belonging to all the other houses are to be established in the same way. Converting them into civil solar [days] by the method explained [above], this is the order of the periods, also known as the order arising from the houses. In that [system], the period produced by the degrees yet to be traversed by the ascendant is declared to be the first [period] of the first house; [the period] comprising the days of the degrees it has already traversed, following the twelfth house, will again belong to the first house. 
atrodāharaṇam | lagnabhāvaḥ $3|4| 3 \mid 8$ dhanabhāvāt 4|1|19|4 śodhito o|27| ${ }_{15} \mid 5^{6}$ jātā sauradinātmikā lagnadaśā $\mid$ atha dhanabhāvaḥ 4|1|19|4 sahajabhāvāc chodhito $27|15| 56$ jātā dhanabhāvadaśā dinādyā | evaṃ sarvatra | atha bhāvāntarāṃśāḥ $27|15| 56$ triśatyā gunitāḥ șaștyopary upari labdhena yutāḥ 8179|40 karkodayena 343 bhaktā labdhāni 23|5o|5o lagnatāsīradaśādināni | evaṃ sarvatra | varșapraveśakālād eșu divaseșu lagneśasya candrasya phalaṃ śubham aśubham vā jñeyam | evam anyatrāpi ||

atha vyayabhāvasaṃdhị̣ $2|17| 41 \mid 6$ lagnabhāve $3|4| 3 \mid 8$ hīnaḥ 16|22|o2 jātā lagnabhuktāṃsāḥ | atha lagnabhāvo $3|4| 3 \mid 8$ lagnasaṃdhau $3|17| 41 \mid 6$ ūnah 13|37|58 jātā lagnabhogyāṃśāḥ | atha lagnasamndhị̣ 3|17|41|6 dhanasaṃdhau 4|14|57|2 ūnaḥ 27|15|56 jātā dhanabhāvadaśā sauradinādyā pūrvāgatasamaiva | atra prathamạ̣ varṣapraveśakālalagnabhogyāṃśadinatulyā lagnadaśā | punar dhanādīnāṃ jñeyā| vyayabhāvadaśāprānte lagnabhuktāṃśadivasasamā lagnadaśā jñātavyeti ||

athaite daśādivasāḥ $27|15| 56$ māsasaurasāvanadivasair $30|26| 17 \mid 37$ gomūtrikayā guṇitāḥ 83o|34|54|35 triṃśatā bhaktāḥ 27|41|9|49 jātāni saurasāvanātmakāni daśādināni | evaṃ sarvatra | atha māsapraveśe bhāvāntarāṃśā dvādaśabhaktā māsapraveśe grahāṇāṃ bhāvatasīradaśādināni syuḥ | dinapraveśe 'pi bhāvāntarāṃśāḥ șaḍbhaktā dinapraveśe grahāṇām bhāvatasīradaśāghațyah syur iti viśeșah ||

$13|4| 3 \mid 8] 3|4| 38$ T $\quad 1-2$ dhanabhāvāt ... atha] om. K T M $\quad 1 \quad 4|1| 19 \mid 4]$ 4|o|19|4 G $\quad 2 \quad 4|1| 19 \mid 4]$ 4|o|19|4 T $\left.3{ }_{27}^{27}|5| 56\right]$ oo4|7|15|56 K; 4|7|15|56 M || jātā] sauradinātmako lagnadaśā atha add. K T; sauradinātmikā lagnadaśā $\|$ atha add. M \| bhāva] bhāvaḥ K T M 4 triśatyā] triṃśatyā B N a.c. || șaștyopary] șașțopary B N $\quad 5$ 8179|40] 81|79|40 K T M || karkodayena] kakaudayena K || 23|5o|5o] 23|23|5o|5o K T M 6 kālād eșu] kālādișu K T M \|| divaseșu] om. B N 8 bhāva] om. B N || 2|17|41|6] 2|27|41|6 G; 3|17|41|36 K; 3|27|41|6 T; 3|17|4|36 M \|

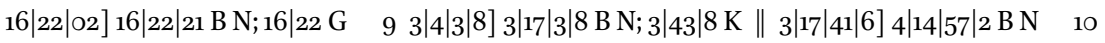
$\left.{ }_{13}|37| 5^{8}\right]$ scripsi; $27|15| 56$ B N; 13|17|58 G K T M $\quad$ 10-11 saṃdhau] saṃdhi G p.c. $\left.\quad 1127\right] 2 \mid 7$ G || saura] sauri K M 12 kāla] kāle T M 13 daśāprānte] daśātrāṃte B N 15 30|26|17|37 $\left.{ }_{20}{ }_{26} 6\right|_{17} \mid 37$ M $\quad 16$ 830|34|54|35] 8|30|34|54|35 B N T M || 27|41|9|49] 27|41|9|59 K M 19 dina ${ }^{2}$ ] dināṃ B N p.c. $\quad$ 20 viśeșaḥ] śeșah B $\mathrm{N}$

40 One degree of ascensions corresponds to just under four minutes of clock time. In Indian time units, this is one sixth of a ghați, or 10 palas. The estimation of the rising times or oblique ascensions of Cancer to 343 palas thus corresponds to $34^{\circ} 18^{\prime}$, or some 2 hours 17 minutes of clock time. It is not stated whether this figure is meant to refer to the tropical or the sidereal zodiac (cf. section 1.4 above), or for what place it is calculated, but it is a close match for the rising times of sidereal Cancer at Rajmahal, Jharkhand.

41 While this calculation is incorrect, it is not clear how the text should be emended, or indeed whether it should be emended at all, as the error might conceivably be one of calculation rather than transmission, and thus originate with Balabhadra himself. The figure $27 ; 15,56$, carried over from the previous paragraph, seems to be correct, as 
Here is an example: the house [cusp] of the ascendant $(3,4 ; 3,8)$ subtracted from the second house [cusp] $(4,1 ; 19,4)$ gives a period of 27;15,56 in solar days for the ascendant. Next, the second house [cusp] $(4,1 ; 19,4)$ subtracted from the third house [cusp] gives a period of 27;15,56 days and so on for the second house, and so throughout. Now, the interval of 27;15,56 degrees between the houses, multiplied by three hundred and increased by any product exceeding sixty, [gives] 8179;40. Divided by the oblique ascensions of Cancer, 343 [palas], it gives 23;50,50 days for the tāsirra period of the ascendant, and so throughout. ${ }^{40}$ On these days, [counted] from the time of the revolution of the year, it should be determined whether the result of the ruler of the ascendant [and] of the moon is good or evil; likewise at other [period days].

Next, the junction of the twelfth house $(2,17 ; 41,6)$ subtracted from the house [cusp] of the ascendant $(3,4 ; 3,8)$ gives $16 ; 22,2$ degrees already traversed by the ascendant. Then, the house [cusp] of the ascendant $(3,4 ; 3,8)$ subtracted from the junction of the ascendant $(3,17 ; 41,6)$ gives $13 ; 37,5^{8}$ degrees yet to be traversed by the ascendant. Next, the junction of the ascendant $(3,17 ; 41,6)$ subtracted from the junction of the second house $(4,14 ; 57,2)$ gives a period of 27;15,56 solar days and so on for the second house, exactly the same as above. Here, the period of the ascendant corresponding in days to the degrees yet to be traversed by the ascendant at the time of the revolution of the year [comes] first; then [the periods] of the second house and so on should be understood [to follow]; and as the period of the twelfth house ends, the period of the ascendant corresponding in days to the degrees already traversed by the ascendant should be understood [to occur].

Now, these 27;15,56 days of a period, multiplied by the 30;26,17,37 civil solar days in a month through the cow's-urine [procedure to give] 830;34,54,35 and divided by thirty, give $27,41,9,49$ civil solar days in a period; and so throughout. ${ }^{41}$ Next, the intervals of the houses in degrees in a monthly revolution, divided by twelve, will be the [solar] days of the tāsira periods of the houses of the planets in [that] monthly revolution. And in a daily revolution, the intervals of the houses in degrees, divided by six, will be the ghatīs of the tāsirra periods of the houses of the planets in [that] daily revolution. ${ }^{42}$ This is a special rule.

does the approximate value of $30 ; 26,17,37$ days in a month. (More precisely, one twelfth of the value $365 ; 15,31,3$ o days given for the year in sections 1.6 and 7.1 above would be $30 ; 26,17,37,30$.) It is also correct that $830 ; 34,54,35$ divided by 30 yields approximately $27 ; 41,9,49$; but the figure $830 ; 34,54,35$ itself cannot be derived from the foregoing values. sentences, appears superfluous. The periods in this system do not belong to the planets as such, but rather to the houses. 
atha sthūlabhāvatasīradaśā tājikasāre |

bhāvasya cordhvānkamitị śaraghnī hìnā svarāmendulavair dinādyā | spașțā daśā lagnamukhādikānām jñeyā phalāny atra budhaih svabhāvāt ||

udāharaṇam | lagnam 3|4|3|8 asyordhvānikamitị 3 śaraghnī 15 svatrayodaśāmsśena dinādinā 1|9|14 hīnā 13|50|46 jātā lagnadaśā dinādikā | evaṃ samastabhāvānāṃ daśā jñeyāḥ | ete daśāhā aṃśādityāgāt sthūlāḥ | atra śūnyamite bhāvordhvāñke dvādaśarāśayah pañcagunāḥ kartavyā iti viśeșah | atra sarvatra bhāvānāṃ daśādinayogah șașțyadhikaṃ śatatrayaṃ bhavati || atha varșe bhāvadaśā trailokyaprakāśe uktā |

tanvādibhāñkaguṇitābdhidinādrirāma-

nādyo daśās tanumukheśavaśád bhavanti |

tāsām vyayārimrtigasya na śobhanā syād

varșe daśām susaralāṃ dhișaṇo jagāda || iti |

atha varṣe kālahorādaśā | uktaṃ ca muktāvalyām |

3 spaștā] jñeyā B N 4 3|4] 34 N || 8] om. B N || asyo-] atro- G K T M || 15] 5 B N 5 1|9|14] 4 B N \| 46] 56 B N \| dinādikā] dinādi B N 6 ete] daśā jñeyā ete add. G \| daśāhā aṃsádi] daśānnampśādi B N 7 viśeșaḥ] śeșaḥ G K T M 8 atra ... bhavati] om. B N \| daśãdina] daśādi K T M 9 atha] atra K T M 10 dinādri] madinādri B N 11 daśās] dṛsāās G ॥ mukheśa] mukheṃśa K T M 13 daśāṃ] daśâś M \| susaralāṃ] svapnaralāṃ B N; syusaralān K T; ca saralān M \| dhiṣaṇo] dhiṣaṇe T M

2-3 bhāvasya ... svabhāvāt] TS $35^{1}$ 
Next, the rough tāsìra periods of the houses [are described] in Tājikasāra [351]:

The first numeric value of a house, multiplied by five and less by one thirteenth, should be understood to be the true period of [the houses] beginning with the ascendant in days and so on; the results in this [period should be understood] by the learned according to the nature [of the houses].

An example: the ascendant is at 3, 4;3,8. Its first numeric value (3), multiplied by five (15) and less by one thirteenth (1;9,14 in days and so on), gives a period of 13;50,46 in days and so on for the ascendant. The periods of all the houses should be understood in the same way. These period days are [called] 'rough' because the degrees and so on are omitted. Here, if the first numeric value of a house is zero, twelve signs are to be multiplied by five: this is a special rule. In every case here, the sum of the period days of the houses is three hundred and sixty.

Next, the periods of the houses in a year are described in the Trailokyaprakāśa:

Four days and thirty-seven nāạis, multiplied by the numbers of the sign of [the houses] beginning with the ascendant, are the periods, [giving results] according to the rulers of [the houses] beginning with the ascendant. ${ }^{43}$ Among them, [the period] of [a planet] occupying the twelfth, sixth or eighth house will not be good. [This] very simple period [system] was described by Dhișaṇa.

\subsection{The Periods Based on Planetary Hours}

Now, the periods of the hours in a year; and it is said in [Tājika]muktāvali[țippañi 3.22-26]:

43 With only a slight error margin due to rounding, this will give the same result as the method just described, as $5 \times 12 / 13 \approx 4 ; 37$. 
varșasvarāṃśapramitāni kecit procur dināni dyusadām daśānām | kālākhyahorādhipatikrameṇa tatsādhanopāyam atha pravacmi $\|$ vārapravrtter gatanāọikās tu dvighnāh śarāptā gatakālahorāḥ| dineśvarāt șașțhakașașthakānukrameṇa yah syād atha vartamānah \| ādyā daśa tasya parāh pareșām tatșașthașașțakramato 'khilānām | śarāptaśeșaṃ tu gatābhidhānam eșyạ̣ tu tad vāṇaviśuddhaśeșam \| ubhe tu varșādrilavena nighne śaroddhrte sto gatagamyamāne | dinādike ādidaśädhipasya gamyonmitādau tu daśā hi tasya \| parāḥ pareșāṃ tuyathāsthitāḥ syur gatonmitā ceti daśädimasya | gataisyamāsāntaratas tu māse yātaisyaghasrāntarato dine 'pi ||

atrodāharaṇam | tatra śrāvaṇavadinavamyāṃ śukravāsare udayād gataghațīpaleșu $5 \mid 36$ varșapraveśah | tatra raviḥ 3|9|36|59 dinamānaṃ 33|30 | atra kālahoreśānayanārthaṃ vārapravṛttyānayanāya sugamopāyo miśrakṛtaḥ |

rekhāsvadeśāntarayojanaih palair nijānghrihīnaih śaravedaghatyaḥ| yutonitāh prākparato dinārdhayuktāh sphuțas tair dinapapraveśạ̣ \|

1 varṣa] varṣe $\mathrm{K}$ T M $\|$ pramitāni] pratitāni $G \quad 3$ nāḍikās] nādikās $G \quad 5$ șașțha1] șașțhya B N || șașțhaª ] șașțhyā B N G || 'khilānām] liśānāṃ B; liśīnāṃ N 6 śarāptaśeșaṃ] śarāptan tașta K; śarāptataștan M \| eșyaṃ] ayyam B N 7 lavena] valena K T; balena M \| sto] staṃ M \| gata] mata G 9 tu] bu B N \| daśādimasya] daśādinasya G; daśā hi tasya K T M 10 māsāntaratas] māsāṃtarajas B N 11 śrāvaṇavadi] śrāvaṇadi $G$ a.c.: śrāvaṇadina $G$ p.c. T 11-12 ghațīpaleșu] ghațịṣu B; ghațiṣu N 12 59] 9 G; om. K T M 13 pravṛttyānayanāya] pravṛttanayanāya K; pravṛttyāyanaya T; pravṛttinayanārthaṃ M 14 nijānghri] nijāghni B 15 dinapa] dina $\mathrm{K}$; divasa $\mathrm{M}$

1-10 varșa ... 'pi] TMṬ 3.22-26 14-15 rekhā ... praveśaḥ] Cf. RV 3

44 The reference here is to the standard Indian order of the planets, which is the order of the days of the week. Thus, as Friday is the sixth day in order from Sunday (counting inclusively), the hour of Venus follows that of the sun, etc. The resulting order of the hours is the so-called Chaldean order of the heavenly bodies, based on their apparent velocity (sometimes expressed as the order of their respective spheres): Saturn, Jupiter, Mars, the sun, Venus, Mercury and the moon. Although the order of the daily rulers is conceptually derived from that of the hourly rulers rather than vice versa, the former would be better known to an Indian readership. 
Some have assigned days comprising one seventh of the year to [each of] the periods of the planets, in the order of the rulers of the hours. I shall now describe how to derive those [periods]. The nādīs elapsed from the beginning of the day of the week, multiplied by two and divided by five, are the elapsed hours. The first period belongs to whichever [planet] is the current [ruler of the hour], taking every sixth [planet] in order from the ruler of the day, and the following [periods] to every sixth [planet] following in order from that [ruler]. ${ }^{44}$

The remainder after dividing [the doubled ghațis] by five is called the elapsed [part]; that remainder subtracted from five is the remaining [part]. These two [values] multiplied by one seventh of the year and divided by five are the durations of the elapsed and remaining [parts, respectively] of the ruler of the first period in days and so on. The period of that [planet], comprising [only] the remaining [part, comes] first; next, [the periods] of the other [planets] will come in order, and [last] the period of the first planet, comprising [only] the elapsed [part]. In [the revolution of] a month, [the calculation is made] from the interval between the preceding and following month; in [the revolution of] a day, from the interval between the preceding and following day.

Here is an example: the revolution of the year was on the ninth [lunar day] of the dark fortnight in [the month of] Srāvaṇa, on a Friday, at 5 ghațīs 36 palas after [sun]rise. ${ }^{45}$ The sun in that [figure] was at 3, 9;36,59, and the length of day was $33 ; 30[$ ghațis $]{ }^{46}$ For the purpose of calculating the hourly rulers, here is an easy method for calculating the beginning of the day of the week, devised by Miśra:

Forty-five ghațis, added to or less by palas [equal to] the easterly or westerly distance in yojanas of one's location from the meridian minus one quarter, are added to half a day: from those [values is known] the true commencement of [the reign of] the ruler of the day.

This is the same astrological figure that was used as an example in section 7.1 above.

46 The length of day is another way of expressing terrestrial latitude. As discussed below, the place for which the figure is cast is Varanasi, around $25^{\circ} 20^{\prime} \mathrm{N}$ (although the Indian tables described by Pingree [1996] give values of $25^{\circ} 24^{\prime}$ to $25^{\circ} 36^{\prime}$ ). By modern recalculation, the length of day at Varanasi for the date in question would be 13 hours 22 minutes or 33;25 ghațis. 
tatra madhyarekhānagarāt gargarātābhidhāt pūrvadiśi kāśî catuhṣașți yojanāni | etāni nijacaturthāṃśa- 16 hīnāni 48 jātāni kāśyāṃ deśāntarapalāni | ebhị̣ palaiḥ śaravedaghatyah pūrvadeśatvād yutā jātāḥ kāśyāṃ dhruvāñkah 45|48 | ayam svadinārdhena 16|45 yuto 62|33 ahorātraghațikā- 6o hīno jātah sūryodayād gataghațīpaleșu 2|33 vārapravṛttikālah | atha vārapravṛttighațikāḥ $2 \mid 33$ ișțaghațikāsu $5 \mid 36$ hīnā $3 \mid 3$ jātā vārapravṛtter gataghațikāḥ | etā dvigunitāḥ $6 \mid 6$ pañcabhaktā labdhā gatakālahorā 1 | dinādhipāt śukrāt șașțhakașașțhakagaṇanayā dvitīyasya budhasya kālahorā | varṣe asyaiva ādyā daśā | tatah ṣașțhaṣașṭhānukrameṇa candraśanigurubhaumaraviśukrānām sauravarṣa- 36o saptamāṃśena 51|25|42|51|25 dinādinā saurasāvanavarșa- 365|15|31|30 saptamāmśena dinādinā $5^{2}|10| 47|21| 25$ vā mitā krameṇaikaikasya daśā varṣe syāt ||

athādimadaśādhipasya budhasya daśāyā gatagamyakālānayanam | tatra pañcabhaktaśeșam 1|6 gatasamjñam | gatạ̣ 1|6 pañcasu hīnaṃ $3 \mid 54$ jātam gamyasaṃjñam | atha gatam 1|6 varșādrilavena ${ }^{1}|25| 42|51| 25$ gomūtrikayā guṇitam șașțyopary upari yutaṃ ${ }_{5} 6|34| 17|8| 33 \mid 30$ pañcabhaktam labdham ādyadaśāpater dinādi daśāmānaṃ gatasaṃjñaṃ $11|18| 51|25| 42|42|$ atha gamyạ̣ $3 \mid 54$ varșādrilavaguṇam șașțoopary upari yutam $200|34| 17|8|_{31} \mid 30$ pañcabhaktaṃ labdham ādyadaśāpater dinādi daśāmānaṃ gamyābhidhaṃ $40|6| 51|25| 42|18| \mid$

atra vartamānahorāsvāmigrahasyādau daśā gamyakālamitā jñeyā | tataḥ kālahoreśakrameṇa varșādrilavamitānyeșāṃ daśā | punaḥ sarveșāṃ grahā-

1 kāśī] om. B N 2-3 deśāntarapalāni] yojanāni B N; deśāntaraphalāni K T M 3 yutā] yuktā K TM 4 dhruvāṅkaḥ] dhruvāḥ B N \| ahorātra] ahorātri B N 5 sūryodayād] sūryodayādayād G || gata] om. G || 2|33] 33 G 62 2|33] 233 K M || 3|3] 3|2 B N 7 gata $\left.^{1}\right]$ om. K M \| etā] 3|3 K T M \| 6|6] 6|4 B N 8 1] om. G \| șașțhakașașțhaka] pṛthak pṛthag K T M 8-9 budhasya] om. G K T M 9 asyaiva] asya ca K T M \| daśā] vaśā G 10 varșa] varșe K T M || saptamāṃśena] saptāṃśena B N $\left.\quad{ }_{11} 51|25| 42|51| 25\right]$ 51|21|42|1|15 B N; 51|25|42|41|25 $\mathrm{K} \mathrm{M} ; 5_{1}|25| 4241 \mid 25 \mathrm{~T}$ || varșa-] barya N; varșe K T M $\|$ 365|15|31|30] scripsi; $365|15| 31|21| 14$ B; $365|55| 31 \mid 14$ N; $365|15| 31|31| 24$ G K T M $\quad 12$ 52|10|47|21|25] 52|10|47|2125 T || mitā] mitī B N \|| krameṇai-] kraṇai-G 13 athādima] atho dina B N \|| daśādhipasya] daśādhīśasya G KT M \| budhasya] om. KT M \| daśāyā] daśá G KTM 14 bhakta] bhakte G || 1|6] 1|16 GT \| gatạ̣ 1|6] om. K T M || 1|6 $6^{2}$ ] 1|16 G || 3|54] 3|34 B N $\quad 15$ 1|6]1|16 G T 16 șaștyopary upari] șaștyoparṇupari K; șașţhopary upari M $\|$ 8] 18 B N; 5 K M $\quad 17$ dinādi] dinādyaṃ K T M 18 3|54] 3|34 B N || șașțyo-] șașțho- M || 200|34] 20034 B N 19 pater ... daśāâ] om. B N || dinādi] dināni G $\quad 20$ 40] 540 K M \| 42|18] 42|1 G; 4218 T 21 svāmi] svāmino K T M \| jñeyā] jñeyeti K T M || tatạ̣] tatra K T M 22-79o.1 mitānyeșāṃ ... gatakāla] om. B N

47 That is, Varanasi or Benares. Gargarāța is mentioned but not identified in Pingree 1996. The tables cited by Pingree assign latitudes between $23^{\circ} 42^{\prime}$ and $24^{\circ}{ }^{\prime} 7^{\prime}$ north to it, while Balabhadra's figure of 48 palas corresponds to a longitude $4^{\circ} 48^{\prime}$ west of Varanasi, i.e., 
Kāsiì, then, is [situated] sixty-four yojanas to the east of the town [marking] the meridian, called Gargarāta. These [yojanas] less by a quarter (16) give 48 palas of longitudinal difference for Kāśî. ${ }^{47}$ Adding these palas to fortyfive ghațis because it is easterly gives Kāsí a constant of 45;48. This, added to half a day of its own [length] (16;45), [gives] 62;33; subtracting the 6o ghațis of a day and night gives a time of 2 ghațis 33 palas elapsed from sunrise [at Kāsín for the beginning of the day [at Gargarāța]. ${ }^{48}$ Now, the 2;33 ghațīs of the beginning of the day, subtracted from the $5 ; 36$ ghațis sought, give 3;3 ghațis elapsed [at Gargarāta] from the beginning of the day [at Kāśī]. These, multiplied by two (6;6) and divided by five, give 1 elapsed hour. Counting every sixth [planet] from Venus, ruler of the day, the second hour belongs to Mercury, and so does the first period of the year. Then, taking every sixth [planet] in order, the moon, Saturn, Jupiter, Mars, the sun and Venus each in turn will have an annual period comprising one seventh of a solar year (36o), [that is], $51 ; 25,42,51,25$ days and so on, or one seventh of a civil solar year $(365 ; 15,31,30)$, [that is], $52 ; 10,47,21,25$ days and so on. ${ }^{49}$

Next, with regard to the calculation of the time elapsed and remaining of the period of the first period ruler, Mercury, the remainder after dividing [the doubled ghatiss] by five $(1 ; 6)$ is said to be the elapsed [part]. The elapsed [part] $(1 ; 6)$ subtracted from five gives $3 ; 54$, known as the remaining [part]. Now, the elapsed [part] $(1 ; 6)$, multiplied through the cow's-urine [procedure] by one seventh of the year $(51 ; 25,42,51,25)$ and increased by any product exceeding sixty [to give] $56 ; 34,17,8,33,30$, [then] divided by five, gives a value of 11;18,51,25,42,42 in [solar] days and so on known as the elapsed [part] of the period of the first period ruler. Next, the remaining [part] (3;54), multiplied by one seventh of the year and increased by any product exceeding sixty [to give] 200;34,17,8,31,30, [then] divided by five, gives a value of $40 ; 6,51,25,42,18$ in [solar] days and so on known as the elapsed [part] of the period of the first period ruler.

Here, the first period of the planet ruling the current hour should be understood to comprise [only] the time remaining. Next, the periods of the other [planets follow, each] comprising one seventh of the year, in order of

around $78^{\circ}$ east. These coordinates are close to the small town of Gairatganj in presentday Madhya Pradesh $\left(23^{\circ} 25^{\prime}\right.$ north, $78^{\circ} 13^{\prime}$ east $)$.

48 Local sunrise marks the beginning of the astrological day, and hence of the reign of its planetary ruler.

49 Although all text witnesses consulted give a slightly different value for the duration of the civil solar year at this point, the value given for $1 / 7$ of that year agrees rather with the standard year length of $365 ; 15,31,30$ as given in sections 1.6 and 7.1 above, and the text has been emended accordingly. 
ṇāṃ prānte varṣasamāptau vartamānakālahorāsvāmina eva gatakālamitā daśā jñeyeti | evaṃ māsapraveśakālayor antarasaptamāṃśamitā māsapraveśahoreśādidaśā jñeyā | tathaiva dinapraveśe horeśādito dinapraveśakālayor antarasaptamāṃśamitā ghațikādidaśā dinapraveśe jñeyā | atrāpi vartamānahoreśasya gatagamyaṃ pūrvavat sādhyam iti ||

atha devakīrtimatena varṣapraveśādau haddādaśā tājikamuktāvalyām uktā|

haddāṃśā ravisaṃgunās tanugatāḥ śrīdevakīrtyāśrayād

dhaddāsvāmidaśädināny atha tanau yo haddapas tatkramāt |

māse haddalavā dināni khalu māsarkșād dine tatprave-

śarkșād dvighnalavair mitā khalu daśāghatyo grahāṇām smṛtāh ||

lāgnikagrahahaddāṃśā bhuktabhogyāmésasamguṇāh |

taddaśā khāgnibhir bhaktā dvidhā te gatagamyake \|

gamyatulyā tatra daśā haddeśasyādimā bhavet |

tatah parāh pareșām syur yathāvat pustakasthitāh \|

bhuktatulyadinaprakhyā varșānte bhāgrahaddajā |

lagnahaddaisyato haddādaśāḥ khāgnyaṃsakāvadhi

yātaișamāsāntaravāsarādyam hanyāt kharāmāvadhibhogyabhāgaị |

2 praveśa] praveśe $B \mathrm{G}$ a.c. || antara] aṃta $\mathrm{B} \mathrm{N} \|$ saptamāṃśa] saptāṃśa $\mathrm{B} N$ \| māsa ${ }^{2}$ ] sa $\mathrm{N}$ 3-4 tathaiva ... jñeyā] om. G \|| horeśādito ... praveśe] om. B N 5 horeśasya] horesāsya $N$ 6 uktā] om. M $\quad 7$ saṃgunās] sadguṇās M $\quad 7-8$ āśrayād dhaddā] āśrayā haddā B N $\quad 8$ haddapas tat] haddapa t B N 9 māsarkșād dine] māsarkșādi B N 10 -rkṣād dvighna] -rkṣādvighna M || khalu] om. B N || ghațyo] cādyā G 11 lāgnika] lāgnik B N; lagneṃka K TM \| haddāṃśā] scripsi; haddāṃśa B N G KT M \| bhuktabhogyāṃśa] om. G 12 taddaśā] om. B N || gamyake] gamyaka B N G a.c. 13 gamya] gamyā K T M 14 pareșāṃ] pare B N 15 bhukta] bhakta G \| bhāgra] scripsi; bhyāgra B N; nyāgra G K T M 16 haddaișyato] scripsi; haddaikhyāto B N; haddaikhyato G; haddeśato K T M || āvadhi] -āvadhiḥ K T M 17 bhogya] bhogma $\mathrm{N}$

7-10 haddāṃśā ... smṛtāḥ] TM 81 11-16 lāgnika ... -āvadhi] TMṬ 3.2-4 17-792.3 yātaiṣya ... tat] TMT 3.16-17 
the hourly rulers. Then, when [the periods of] all the planets are up, the period of the ruler of the current hour itself, comprising the time elapsed, should be understood [to last] up to the end of the year. Likewise, the periods [of the planets] beginning with the ruler of the hour in the monthly revolution should be understood to comprise one seventh [each] of the interval between the times of two monthly revolutions; so too, in a daily revolution, the periods in ghațis [of the planets reckoned] from the ruler of the hour in the daily revolution should be understood to comprise one seventh [each] of the interval between the times of two daily revolutions. Here, too, the elapsed and remaining [parts of the period] of the ruler of the current hour are to be established as above.

\subsection{The haddā Periods}

Next, the periods of the haddās at the revolution of the year and so on according to the school of Devakīrti are described in Täjikamuktāvali [81 and Täjikamuktāvalititippaṇī 3.2-4, 16-17]:

The degrees of the hadd $\bar{a}$ on the ascendant, multiplied by twelve, are the days of the period of the haddā ruler; then [the periods follow] in order from [the planet] ruling the hadd $\bar{a}$ on the ascendant, on the authority of Śrī Devakīrti. In a month, the degrees in the haddā are the days [beginning] from the sign [on the ascendant] of the month; in a day, the ghatis of the periods of the planets are said to comprise the degrees multiplied by two, [counted] from the beginning of that [day].

The degrees of the planetary hadda relating to the ascendant, multiplied by the degrees traversed and remaining, [respectively], and divided by thirty, are its period in two parts: elapsed and remaining. Of these, the period of the hadda ruler corresponding to the remaining [part of the current haddā] will be first; thereafter [the periods] of the other [planets], just as they are found in books. [The period] in days corresponding to the elapsed [part of the current haddā occurs] at the end of the year, [the counting] commencing from the beginning of the sign. The periods of the haddās [proceed] from the remaining [part] of the haddā on the ascendant up to thirty degrees [of the zodiacal sign].

One should multiply the interval between [the commencements of] the preceding and following months in days and so on by the degrees 
tanusvahaddādhipatikrameṇa vyomānalaị saṃvibhajed dinādyam \| phalaṃ yad āptam dyusadām daśānām mānam bhaven māsaphale sphuțạ̣ tat |

atha devakīrtimatena varṣalagnād varșadaśeśvarāḥ sauradinātmakāḥ | meșādilagneșu daśādināni grahāṇām |

\begin{tabular}{|c|c|c|c|c|c|}
\hline me & br 72 & śu 72 & bu 96 & maṃ 6o & śa 6o \\
\hline vṛ & śu 96 & bu 72 & bṛ 96 & śa $6 o$ & $\operatorname{mam} 36$ \\
\hline $\mathrm{mi}$ & bu 72 & śu 72 & bṛ 6o & mam 84 & śa 72 \\
\hline ka & mam 84 & śu 72 & bu 72 & bṛ 84 & śa 48 \\
\hline $\operatorname{sim}$ & bṛ 72 & śu 60 & śa 84 & bu 72 & $\operatorname{mam} 72$ \\
\hline ka & bu 84 & śu 120 & bṛ 48 & mam 84 & śa 24 \\
\hline tu & śa 72 & bu 96 & br 84 & śu 84 & mam 24 \\
\hline$v r$ & mam 84 & śu 48 & bu 96 & bṛ 60 & śa 72 \\
\hline dha & bṛ 144 & śu 6o & bu 48 & mam 6o & śa 48 \\
\hline $\mathrm{ma}$ & bu 84 & bṛ 84 & śu 96 & śa 48 & mam 48 \\
\hline kum & bu 84 & śu 72 & bṛ 84 & mam 6o & śa $6 o$ \\
\hline mì & śu 144 & bṛ 48 & bu 36 & mam 108 & śa 24 \\
\hline
\end{tabular}

atha māsapraveśe māsalagnān māsadaśeśvarāḥ sauradinātmakāḥ |

\section{yogah}

\begin{tabular}{lllllll}
\hline me & bṛ 6 & śu 6 & bu 8 & maṃ 5 & śa 5 & 30 \\
ṿ̣ & śu 8 & bu 6 & bṛ 8 & śa 5 & maṃ 3 & 30 \\
mi & bu 6 & śu 6 & bṛ 5 & maṃ 7 & śa 6 & 30
\end{tabular}

\footnotetext{
1 vyomānalaih] vyomānilai B N; vyomānilaịh G $\quad 2$ dyusadāṃ] om. B N; dyusadānī K 3 tat] syāt K T M $\quad 4-5$ atha ... grahāṇām] om. B N K T 7 śu 96] bu 72 K T M || bu 72] śu 72 KTM 8 bu 72] śu 96 KTM \| śu 72] bu 42 K M; bu $7_{2}$ T || śa ${ }_{72}$ ] śa 48 B 9 bu 72] bu $84 \mathrm{G}$ T 12 śa 72] śa $32 \mathrm{M} \quad 13$ śu 48] śu 58 B || bu 96] br 84 14 bṛ 144] gu 114 G; bṛ 114 K T M || bu 48] bu 96 B || śa 48] śa 72 B $\quad 15$ śu 96] bu 48 B 16 br 84] śu 96 B 17 śu 144] śu 114 G; śu 1144 K T M \| maṃ 108] ma 18 T; maṃ 18 M 18 atha ... dinātmakāḥ] om. N K T M 19 yogah] om. B 20 bṛ 6] bu 6 B || śa 5] śa B 21 śa 5] maṃ 5 B 22 śa 6] śa B
}

6 me] The following table is omitted by N. 19 yogah] This column is omitted by K T M. $20 \mathrm{me}$ ] The following table is omitted by $\mathrm{N}$. 
[of the rising sign] remaining up to thirty degrees and divide it by thirty in the order [beginning with] the ruler of the hadda of the ascendant itself: the result derived will be the true duration of the periods of the planets in days and so on in a monthly figure. ${ }^{50}$

Here are the rulers of the periods in a year in solar days, [commencing] from the ascendant of the year, according to the school of Devakirti - the days of the periods of the planets in the ascendants beginning with Aries:

\begin{tabular}{|c|c|c|c|c|c|}
\hline Ar & Ju 72 & Ve 72 & Me 96 & Мa 6o & Sa 60 \\
\hline & Ve 96 & Me 72 & Ju 96 & Sa $6 o$ & $\mathrm{Ma}_{3} 6$ \\
\hline $\mathrm{Ge}$ & Me 72 & Ve 72 & Ju 6o & $\mathrm{Ma} 84$ & Sa 72 \\
\hline $\mathrm{Cn}$ & Ma 84 & Ve 72 & Me 72 & Ju 84 & Sa 48 \\
\hline Le & Ju 72 & Ve 60 & Sa 84 & Me 72 & Ma 72 \\
\hline & Me 84 & Ve 120 & $\mathrm{Ju} 48$ & $\mathrm{Ma} 84$ & Sa 24 \\
\hline 1 & Sa 72 & Me 96 & Ju 84 & Ve 84 & Ma 24 \\
\hline Sc & Ma 84 & $\operatorname{Ve} 48$ & Me 96 & Ju 60 & Sa 72 \\
\hline g & Ju 144 & Ve 60 & $\mathrm{Me} 48$ & Мa 6o & Sa 48 \\
\hline $\mathrm{Cp}$ & Me 84 & Ju 84 & Ve 96 & Sa 48 & $\mathrm{Ma}_{48}$ \\
\hline $\mathrm{Aq}$ & $\mathrm{Me} 84$ & Ve 72 & Ju 84 & Ma 6o & Sa 60 \\
\hline $0^{\circ}$ & Ve 144 & $\mathrm{Ju} 48$ & $\operatorname{Me}_{36}$ & Мa 108 & Sa 24 \\
\hline
\end{tabular}

Here are the rulers of the periods in a month in solar days, [commencing] from the ascendant of the month in a monthly revolution:

\section{Total}

Ar Ve 6 Ve 6 Me 8 Ma 5 Sa 5 30

Ta Ve 8 Me 6 Ve 8 Sa 5 Ma 330

Ge Me 6 Ve 6 Ve 5 Ma 7 Sa 6 30

$5^{\circ}$ Literally, 'in the result of the month', that is, a monthly revolution. 
(cont.)

\begin{tabular}{|c|c|c|c|c|c|c|}
\hline & & & & & & yogah \\
\hline $\mathrm{ka}$ & maṃ 7 & śu 6 & bu 6 & bṛ 7 & śa 4 & 30 \\
\hline sim & bṛ 6 & śu 5 & śa 7 & bu 6 & maṃ 6 & 30 \\
\hline $\mathrm{ka}$ & bu 7 & śu 10 & bṛ 4 & maṃ 7 & śa 2 & 30 \\
\hline $\mathrm{tu}$ & śa 6 & bu 8 & bṛ 7 & śu 7 & maṃ 2 & 30 \\
\hline vṛ & maṃ 7 & śu 4 & bu 8 & bṛ 5 & śa 6 & 30 \\
\hline dha & bṛ 12 & śu 5 & bu 4 & maṃ 5 & śa 4 & 30 \\
\hline ma & bu 7 & bṛ 7 & śu 8 & śa 4 & maṃ 4 & 30 \\
\hline kum & bu 7 & śu 6 & bṛ 7 & maṃ 5 & śa 5 & 30 \\
\hline mì & śu 12 & bṛ 4 & bu 3 & maṃ 9 & śa 2 & 30 \\
\hline
\end{tabular}

atha dinapraveśe dinapraveśalagnād dinadaśeśvarāḥ ghaṭikātmakāḥ |

\section{yogah}

\begin{tabular}{|c|c|c|c|c|c|}
\hline me & br 12 & śu 12 & bu 16 & maṃ 10 & śa 10 \\
\hline vṛ & śu 16 & bu 12 & br 16 & śa 10 & mam 6 \\
\hline $\mathrm{mi}$ & bu 12 & śu 12 & bṛ 10 & mam 14 & śa 12 \\
\hline ka & maṃ 14 & śu 12 & bu 12 & bṛ 14 & śa 8 \\
\hline sim & bṛ 12 & śu 10 & śa 14 & bu 12 & mam 12 \\
\hline ka & bu 14 & śu 20 & br 8 & maṃ 14 & śa 4 \\
\hline tu & śa 12 & bu 16 & bṛ 14 & śu 14 & mam 4 \\
\hline
\end{tabular}

3 śa 4] śa B 4 bṛ 6] bu 6 B || śa 7] bu 6 B || bu 6] bu 4 T || mam 6] mam B 5 bu 7] śu 7 B || śa 2] śa B 6 mam 2] mam B 7 bu 8] bu 4 G T \| bṛ 5] mam ${ }_{5}$ G T || śa 6] śa B; śa 4 G T 8 bṛ 12] bṛ 7 B || śa 4] śa B 9 bṛ 7 ] śu 7 B || śu 8] śu 4 B || śa 4] maṃ 4 B || maṃ 4] maṃ B 10 śa 5] śa B $\quad 11$ śa 2] śa B 12 atha] om. B || atha ... ghaṭikātmakāh] om. N \| dinapraveśe] om. G; dinapraveśa M \| dinapraveśalagnād] lagnahaddāyā K T M \| dina²] dine K T M \| daśeśvarāḥ] daśeśāḥ K T M \| ghațikātmakāḥ] ghațavālmikā M; saurāḥ add. K T M 14 bṛ 12] bṛ $62 \mathrm{~K} \|$ bu 16] bṛ 16 B || maṃ 10] om. B; śa 1o G T || śa 10] om. B; mạ̣ G; maṃ 10 T 15 śu 16] śa 16 B \| mam 6] om. B; mam G 16 śa 12] om. B; śa G; śa 8 T 17 śa 8] om. B; śa G; śa $12 \mathrm{~T} \quad 18$ bṛ 12] gu 12 B \|| śu 10] śu oo G \| maṃ 12] om. B; mạ̣ G; śa 4 T 19 bṛ 8] gu 8 B || śa 4] om. B; śa G; maṃ 4 T 20 bṛ 14] gu 14 B || śu 14] śa 14 B || maṃ 4] om. B; maṃ G; śa $12 \mathrm{~T}$

13 yogah] This column is omitted by K T M, while B retains only the heading. 14 me] The following table is omitted by N. In K T M, the abbreviations in the first column have been replaced with the numbers $1-12$. 
(cont.)

\section{Total}

Cn Ma 7 Ve 6 Me 6 Ve 7 Sa 4 30

Le Ve 6 Ve 5 Sa 7 Me 6 Ma 630

Vi Me 7 Ve 10 Ve 4 Ma 7 Sa 230

Li Sa 6 Me 8 Ve 7 Ve 7 Ma 230

$\begin{array}{lllllll}\text { Sc } & \text { Ma } 7 & \text { Ve } 4 & \text { Me } 8 & \text { Ve } & \text { Sa } 6 & 30\end{array}$

Sg Ve 12 Ve 5 Me 4 Ma 5 Sa 430

$\begin{array}{llllll}\text { Cp } & \text { Me } 7 & \text { Ve } & \text { Ve } 8 & \text { Sa } 4 & \text { Ma } 4 \\ 30\end{array}$

Aq Me 7 Ve 6 Ve 7 Ma 5 Sa 5 30

Pi Ve 12 Ve 4 Me 3 Ma 9 Sa 230

Here are the rulers of the periods in a day in ghațis, [commencing] from the ascendant of the day in a daily revolution:

\section{Total}

Ar Ju 12 Ve 12 Me 16 Ma 10 Sa 1060

Ta Ve 16 Me 12 Ve 16 Sa 10 Ma 6 6o

Ge Me 12 Ve 12 Ve 10 Ma 14 Sa 1260

Cn Ma 14 Ve 12 Me 12 Ve 14 Sa 8 6o

Le Ve 12 Ve 10 Sa 14 Me 12 Ma 1260

Vi Me $14_{4}$ Ve 20 Ve 8 Ma 14 Sa 4 6o

Li Sa 12 Me 16 Ve 14 Ve 14 Ma 4 6o 
(cont.)

\begin{tabular}{lllllll}
\hline & & & & & & yogah \\
\hline vṛ & maṃ 14 & śu 8 & bu 16 & bṛ 10 & śa 12 & 6o \\
dha & bṛ 24 & śu 10 & bu 8 & maṃ 10 & śa 8 & 6 o \\
ma & bu 14 & bṛ 14 & śu 16 & śa 8 & mam 8 & 6o \\
kum & bu 14 & śu 12 & bṛ 14 & mạ̣ 10 & śa 10 & 6o \\
mì & śu 24 & bṛ 8 & bu 6 & maṃ 18 & śa 4 & 6o \\
\hline
\end{tabular}

atrodāharaṇam | tatra varṣapraveśe spașțalagnaṃ rāśyādi $4|8| 53 \mid 10$ | atra samjñātantroktā meșe 'ñgatarkāṣtaśareșubhāgā ityādinā haddāmśāā dvādaśaguṇāh bhaumādipañcagrahāṇām vartamānahaddeśvaram ārabhya sauradaśādināni varṣe bhavanti | athātra siṃhalagne șaḍamśsamitā guruhaddā gatā | vartamānā śukrahaddā pañcāṃśāvadhi vartate | tatra vartamānahaddeśvarasya daśāgatagamyajñānārthaṃ vartamānahaddeśvarasya pṛșṭhasaṃsthagrahāṇāṃ haddāṃśāḥ spaṣṭalagnāṃśeṣu 8|53|1o hīnāḥ śeșam lagnagatahaddāyāḥ bhuktam 2|53|10 | bhuktam vartamānahaddeśvarasya haddāṃśeșu 5 hīnaṃ jātam lagnasya haddāyāḥ bhogyaṃ 2|6|50 | bhuktam bhogyaṃ ca dvādaśaguṇaṃ ṣaṣtyopary upari yutam ca jātāni bhuktāni 34|38 bhogyāni 25|22 daśādināni | tatra bhogyadaśādināni vartamānahaddeśvarasyādau jñeyāni | tatạ̣ krameṇānyeșām | tad yathā | siṃhalagne vartamānahaddeśvarasya śukrasya bhogyadinādikā daśā 25|22 tatah śaner daśā dināni 84 budhasya 72 bhaumasya 72 guroh 72 | prānte

3 bu 16] gu 16 B || śa 12] om. B; śa G; mam 8 T 4 bṛ 24] bṛ 14 G \|| śu 10] śu 8 G || bu 8] bu 16 G T \| mam 10] bṛ 10 G T || śa 8] om. B; śa G; śa 12 T M 5 śu 16] bu 16 B \| mạ̣ 8] om. B; maṃ G 6 bu 14] bṛ 14 B || śa 10] om. B; śa G 7 maṃ 18] mam 16 B || śa 4] om. B; śa G $\quad 8$-10 $4|8| 53 \mid 10$... bhaumādi] om. BN 9 -oktā] -oktaṃ KTM 10 bhaumādi] bhaumā G || grahāṇāṃ] krahāṇām B N 11 daśādināni] daśādinā B N || șaḍaṃśa] șașthaśa N 12 -āvadhi] -āvadhir M 13 haddeśvarasya] haddeśvara B N K T M || daśā] om. G || gamyajñānā-] gamyannānā M 14 prșțha] om. G N \|| prșțha ... grahāṇāṃ] șțaṇāṃ N \| prșțtha ... spa-] om. B 15 gata] om. G T \| haddāyāḥ bhuktam] haddāyām uktaṃ M \|| bhuktam¹] om. N || 2|53] om. B N 16 haddāyāḥ] haddāyoḥ N || 2|6|5o] 216|5o K M 18 25] o5 K || 22] om. B N \| tatra ... dināni] om. B N 19 tad yathā] rudyathā G 20 śukrasya] śukra B N

9 meșe ... bhāgā] ST 1.33

11 bhavanti] At this point $\mathrm{G}$ mistakenly adds: athātra siṃhalaṣaḍamśāmitā guruhaddā vartamānaśukrahaddā paṃcāmeśāvadhi vartate tatra vartamānahaddeśvaram ārabhya sauradaśādināni varșe bhavamiti. 


\section{Total}

\begin{tabular}{llllll} 
Sc Ma 14 & Ve 8 & Me 16 & Ve 10 & Sa 12 & $6 \circ$ \\
Sg Ju 24 & Ve 10 & Me 8 & Ma 10 & Sa 8 & $6 \circ$ \\
Cp Me 14 & Ve 14 & Ve 16 & Sa 8 & Ma 8 & $6 \circ$ \\
Aq Me 14 & Ve 12 & Ve 14 & Ma 10 & Sa 10 & $6 \circ$ \\
Pi Ve 24 & Ve 8 & Me 6 & Ma 18 & Sa 4 & $6 \circ$ \\
\hline
\end{tabular}

Here is an example: in that revolution of the year, the exact ascendant in signs and so on was at 4, 8;53,10. Here the degrees of the haddās, stated in Samjñātantra [1.33-38] with the words 'In Aries, six, six, eight, five and five degrees' and so forth, multiplied by twelve, become the annual periods in solar days of the five planets beginning with Mars, ${ }^{51}$ starting from the ruler of the current haddā. Here, then, in Leo ascendant, the hadda of Jupiter extends up to six degrees; the current hadda of Venus terminates at [a further] five degrees. To find the elapsed and remaining [parts] of the period of that currect haddā ruler, the degrees of the haddās of the planets prior to the current hadda ruler are subtracted from the exact degrees of the ascendant $(8 ; 53,10)$; the remainder is the elapsed [part] of the haddā occupied by the ascendant $(2 ; 53,10)$. The elapsed [part] of the current hadda ruler subtracted from the [total] degrees of the hadd $\bar{a}$ (5) gives the remaining [part] of the hadda of the ascendant $(2 ; 6,50)$. Both the elapsed and the remaining [parts], multiplied by twelve and increased by any product exceeding sixty, give 34;38 elapsed and 25;22 remaining days of the period. Of these, the remaining days of the current haddā ruler's period should be understood [to come] first, then the others in order, as follows: in Leo ascendant, the remaining period of the current hadd $\bar{a}$ ruler Venus in days and so on are 25;22; then the period of Saturn is 84 days; that of Mercury, 72; that of Mars, 72; that of

51 That is, the planets excluding the sun and moon. 
bhuktāṃśād ānītadaśā $34 \mid 38$ vartamānahaddāsvāmina eva jñeyā | evaṃ ṣaștyaādhikaṃ śatatrayaṃ daśādināni bhavanti | atra madhye yadi rāśisamāptis tadā punā rāśiprārambhahaddāsvāmino daśāhāḥ syuh | yathānte bhaumadaśāyāḥ siṃhalagnasamāptau rāśiprārambhahaddāsvāmino guror daśā punar jāteti \|

atha māsapraveśe rāśyādi lagnaṃ $2|15| 17$ | atrāpi pūrvavan mithunalagne șạ̣amísamitā budhahaddā șaḍamśamitā ca śukrahaddā gatā | vartamānahaddeśvaro guruh pañcāṃśāvadhi vartate | tasya bhuktạ̣ $3 \mid 17$ bhogyam ca $1|43|$ māse haddalavā dināni ity uktatvād vartamānahaddāṃsá eva haddāsvāmidaśādināni | tatra bhogyadināni 1|43 mitā daśā ādau guroḥ tatah pustakalikhitakrameṇānyeșāṃ daśādināni maṃ 7 śa 6 bu 6 śu 6 | ante bhuktadivasamitā $3 \mid 17$ guror eva daśā | evaṃ sarvatra ||

atha dinapraveśe lagnam rāśyādi 1/12|17 | atra vrṣalagne așțāṃśamitā śukrahaddā gatā | vartamānā șạ̣aṃśamitā budhahaddā | tatra budhahaddābhuktaṃ $4 \mid 17$ bhogyaṃ ca 1|43 budhavarșadaśāhair 72 guṇitam triṃśadbhaktaṃ jātam budhadaśābhuktam ghațikātmakaṃ $8 \mid 34$ bhogyaṃ ca 3|26 | yad vāṃśādi bhuktaṃ bhogyaṃ ca dviguṇaṃ ghațikādi daśābhuktaṃ bhogyam ca bhavati | atra bhogyaghațikātmikā ca ādau vartamānahaddeśvarasya budhasya daśā $3 \mid 26$ | tatah pustakalikhitakrameṇānyeșāṃ haddeśvarāṇāṃ | haddāṃśāḥ dvigunāḥ daśāghațikāḥ syuh guroḥ 16 śaneh 10 bhaumasya 6 śukrasya 16 | prānte bhuktaghațikādikā $8 \mid 34$ budhasya daśā | evaṃ sarvatra|

\footnotetext{
1 ānìtadaśā] ānītā taddaśā K T M $\quad 2$ yadi] ya G $\quad 3^{-4}$ daśāhāḥ ... svāmino] om. B N \| yathānte bhaumadaśāyāḥ] scripsi; yathāṃtar bhaumadaśāyāṃ G; yathāntar bhaumadaśāyāṃ K T; yathāntabhaumadaśāyāṃ M $\quad 5$ jāteti] jīveti M $\quad 6 \quad 2$ 2] om. B N $\quad 8$-āvadhi] -āvadhir M 9 ca] om. B || lavā] lavād T M \| dināni ity uktatvād] dinānī tvād B; dinānītvād $\mathrm{N}$; dināny uktatvād K T M 10 haddā] om. G \| daśādināni] daśādinā G || bhogya] rbhāgya G $\quad 117$ śa 6] 72|6 B N 14 tatra] om. KT M $14-15$ budhahaddā] om. GKTM 1572$]\left.7\right|_{2} ^{2}$ M 16-17 ghațikātmakaṃ ... bhuktam² ${ }^{2}$ om. B N 17 26] 6 G $\|$ vāṃśādi] aṃsāãdi G 18 ca $^{2}$ ] om. G K T M 19 budhasya] budha G 20 haddāṃśāḥ] hṛddāṃśāḥ G; haddāṃśād M || 16] 15 G T 21 ghațikādikā] ghaṭikā B N || 34] om. B N
}

9 māse ... dināni] TM 81 10 haddā ... dināni'1] TM 81 
Jupiter, 72; and the period of 34;38 of the current hadda ruler itself, calculated from the elapsed degrees, should be understood [to occur] at the end. Thus the [total] days of the periods come to three hundred and sixty. If the zodiacal sign is completed within this [time], then the period days revert to the ruler of the ruler of the hadda at the beginning of the sign - as when, with the end of the period of Mars, Leo ascendant is completed, the period reverts to Jupiter, ruler of the hadd $\bar{a}$ at the beginning of the sign.

Next, in a monthly revolution, the ascendant in signs and so on is 2, 15;17. Here, too, [we calculate] like above: in Gemini ascendant, the hadda of Mercury, comprising six degrees, and the haddā of Venus, [also] comprising six degrees, have passed. The current haddā ruler Jupiter terminates at [a further] five degrees. Its elapsed [part] is 3;17 and its remaining [part], 1;43. Because it was said [in Tājikamuktāvali 81, quoted above] that 'in a month, the degrees in the hadd $\bar{a}$ are the days', the degrees of the current hadd $\bar{a}$ are themselves 'the days of the period of the haddā ruler'. Of these, the period comprising the remaining 1;43 days of Jupiter [comes] first; then the period days of the other [planets], in the order [of haddās] written in books: $\mathrm{Ma}[\mathrm{rs}$ ], 7; Sa[turn], 6; Me[rcury], 6; Ve[nus], 6; last, the period of Jupiter itself, comprising its 3;17 elapsed days; and so throughout.

Next, in a daily revolution, the ascendant in signs and so on is 1, 12;17. In this Taurus ascendant, the hadda of Venus, comprising eight degrees, has passed; the current haddā of Mercury comprises six degrees. Of these, the elapsed [part] of Mercury's haddā (4;17) and its remaining [part] (1;43), multiplied by the days of Mercury's period in a year $(72)$ and divided by thirty, give 8;34 as the elapsed [part] of Mercury's period in ghațis, and 3;26 as the remaining [part]. ${ }^{52}$ Or else, the elapsed and remaining [parts] in degrees and so on, doubled, become the elapsed and remaining [parts] of the period. ${ }^{53}$ Of these, the period consisting of the remaining 3;26 ghațis of the current haddā ruler Mercury [comes] first; then [the periods] of the other [haddā] rulers, in the order [of haddās] written in books. The degrees of the haddās doubled will be the ghațis of the periods: 16 for Jupiter, 10 for Saturn, 6 for Mars, 16 for Venus; last, the period of Mercury's elapsed [part], 8;34 in ghațīs and so on; and so throughout.

$5^{2} \quad$ Although the text witnesses agree on this procedure, it is incorrect. The degrees with fractions must be multiplied by 6o (the number of ghațīs in a nychthemeron) and divided by 30 (the number of degrees in a sign) to arrive at the values given: 4;17 $\times 60$ / $30=8 ; 34$. The error appears to be one of calculation rather than transmission. 
athaiṣāṃ saurānāạm daśādivasānāṃ saurasāvanajñānārtham sugamopāyas tatraiva |

dvighnasvaśailaviśvāmeśayutā ete 'khilāh smrtāḥ| paleșu kvagnibhāgā d̆hyā jāyante saurasāvanāh || iti |

udāharaṇam | śanidaśādināni saurāṇi 84 | eșāṃ śailaviśvāmusśo dinādikaḥ o|36|47 dvighnaḥ 1|13|34 daśādivaseșu 84 yutaḥ 85|13|34 | paleșu 34 daśādinānāṃ kvagnibhāgena 2 yutaḥ 36 jātāni śanidaśādināni 85|13|36 saurasāvanāni | evaṃ sarveșu daśādivaseșu saurasāvanatā kartavyeti | atha māsadaśāsaurasāvanīkaraṇe prakārāntaras tatraiva |

varșārkabhāgena yadīnasāvanā daśā imāḥh syur dyusadāṃ dinādikāḥ| tadeștamāsāntaravāsaraị̣ kìyanmitāḥ prasādhyā iti vātra māsajāh ||

atha varṣe grahāṇāṃ nisargadaśā tatraivoktā |

rāśiśsvarād vendubale 'bjabhaumavicchukrajīvārkapatañgajānām| trighnāh śaśí dvau navakam nakhāni dhṛtị̣ krtị̣ pūrṇaśarā dināni $\|$

1 sāvanajñānārthaṃ] sāvanīkaraṇārthaṃ G K T M 3 viśvāṃśa] viśvāṃ B N; viśvāṃśā K; viśvāmáāạ T M 4 bhāgāạhyā] bhāgādyā N G || jāyante] jāgaṃte N 5 eșāṃ] eteșāṃ G || viśvāmśo ] dviśvāṃśo B N 6 o] om. B N G \| 36] 3 gha G \| 13²] 12 B N $\quad 6-7$ dinānāṃ] 84 add. G K T M 7 bhāgena] bhāge ca B N || 2] om. K T M || 13] 33 K M || sāvanāni] sāvanadināni B N 8 sāvanatā] sāvana B N 9 -āntaras] -āntaraṃ M \| tatraiva] tatraivoktaḥ K T; tatraivoktam M 10 bhāgena] bhogena $G \|$ yadīna] yadā na $G$ \| sāvanā] sādanā K T 12 atha] atra $\mathrm{G} \quad 13$ rāśsiśvarād vendubale 'bja] rāśiśvarādidurbalejva $B$

3-4 dvighna ... sāvanāḥ] TM 90 10-11 varṣārka ... māsajāḥ] TMṬ 3.41 13-802.2 rāśśśvarād ... haddataḥ] TM 88-89 
Next, an easy method for finding the civil solar [equivalent] of these solar period days [is described] in the same place [Täjikamuktāvali 9o]:

All these, added to twice their own one hundred and thirty-seventh parts and increased in [the place of] the palas by a thirty-first part [of the result], are said to be converted into civil solar [days].

Example: the period of Saturn has 84 days. A one hundred and thirty-seventh part of these in days and so on $(0 ; 36,47)$, doubled $(1 ; 13,34)$ and added to the [solar] days of the period (84) is 85;13,34. Adding a thirty-first part of the period days (2) to the palas (36) gives $85 ; 13,36$ civil solar days for the period of Saturn. The [solar] days of all periods are to be converted into civil solar [days] in this way. Next, another method for converting the periods of [solar] months into civil solar ones [is described] in the same place [Täjikamuktāvalițippaṇi 3.41]:

Or else, the monthly [periods] may be established in this way: if, by dividing the year by twelve, these will be the [monthly] civil solar periods of the planets in days and so on, then how many [civil solar days] will be comprised by the interval in [solar] days between the months sought?

\subsection{The Natural Periods of the Planets}

Next, the natural periods of the planets in a year are described in the same place [Tājikamuktāvali 88-89]:

Or, if the moon is strong, the moon, Mars, Mercury, Venus, Jupiter, the sun and Saturn have three times one, two, nine, twenty, eighteen, twenty and fifty days, [respectively, counted] from the ruler of the sign 
șadamiśatulyāḥ syus tāsām nādikā dyuphale daśāḥ|

bhaveyur divasārambhavartamānabhahaddataḥ ||

varșe candrasya sabalatve candrarāśśśakramato nisargadaśeśvarāḥ syuh | varṣadaśāyā dvādaśāṃśena māsadaśā jñeyā | varṣadaśāṣaḍaṃśena ghaṭikādyā dinadaśā bhavati |

naisargikadaśā ghasravidhuvīryoccaye smrtā |

tadādimadaśābhuktabhogyam candrarkșapād bhavet \|

candrarāssiśabhuktaisyabhāgair nighnā ca taddaśā |

khāgnibhaktā gataisyam tad antādau syād dinādikam \|

candreśvarasya madhye tu tatkrameñānyakhețajā |

varṣamāsadinapraveśe grahāṇāṃ nisargadaśācakram adaḥ|

\begin{tabular}{llll}
\hline $\begin{array}{l}\text { nisarga- } \\
\text { daśāḥ }\end{array}$ & $\begin{array}{l}\text { varșa- } \\
\text { daśāhāḥ̄ }\end{array}$ & $\begin{array}{l}\text { māsa- } \\
\text { daśāhāḥ }\end{array}$ & $\begin{array}{l}\text { dinadaśā- } \\
\text { ghațikāḥ }\end{array}$ \\
\hline candraḥ & 3 & 015 & 030 \\
mañgalaḥ & 6 & 030 & 10 \\
budhạ̣ & 27 & 215 & 430 \\
śukraḥ & 60 & 50 & 100 \\
bṛhaspatiḥ & 54 & 430 & 90 \\
sūryaḥ & 60 & 50 & 100 \\
śaniḥ & 150 & 1230 & 250 \\
yogaḥ & 360 & 300 & 600 \\
\hline
\end{tabular}

1 șaḍ] șțaḍ G || tulyāḥ syus] tulyās te G 2 bhahaddatậ] hadda B $\quad 4^{-5}$ ghațikādyā] ghațikā B N 6 vīryoccaye] scripsi; vīryāghațah B N; vīryāc ca ye G K T M 7 candrarkṣapād] caṃrdrapād B; caṃdrarkṣayād G $\quad 9$ antādau] daṃśādau B $\quad 11$ varṣa ... adaḥ] om. B $\quad 12$ varșa] varșe $\mathrm{G}$ || māsa] māse G $\quad 13$ ghațikāḥ] scripsi; -hāḥ B; veghā G $\quad 16 \quad 215] 115 \mathrm{G} \quad 17$ 10 o] 1 oo G 21 yogaḥ] scripsi; nisargadaśeśāgraḥ $G$ \| 36o] varșadaśāyogaḥ add. G || 30 o] māsadaśāyogah add. G || 6o o] dinadaśāghațikāyo add. G

6-10 naisargika ... khețajā] TMṬ 3.11-13

12 nisarga-] The following table is omitted by N K T M, while B G give the names of the planets in abbreviated form. The last row is omitted by $\mathrm{B}$. 
[occupied by the moon]. ${ }^{54}$ In a daily figure, ${ }^{55}$ the periods in $n \bar{a} d \bar{l} \bar{s}$ will equal a sixth of these [periods] and begin with [the ruler of] the current hadda in the sign [occupied by the moon] at the beginning of the day. ${ }^{56}$

When the moon is strong in the year, the order of the rulers of the natural periods will be from the ruler of the sign of the moon. The periods in a month are to be understood by dividing the periods in a year by twelve. The periods in a day, in ghațis and so on, are produced by dividing the periods in a year by six. [Continuing from Tãjikamuktāvalițippaṇi 3.11-13:]

The natural periods are declared for when the moon of the day has gathered in strength. The elapsed and remaining [parts] of its first period will be from the ruler of the sign of the moon. Its period, multiplied by the elapsed and remaining degrees of the ruler of the sign of the moon and divided by thirty, will be the elapsed and remaining [parts] at the end and beginning, [respectively], in days and so on. Within [the period] of the ruler of [the sign of] the moon, [there will be subperiods] of the other planets in that [same] order.

This is a table of the natural periods of the planets in an annual, monthly and daily revolution:

\begin{tabular}{llll}
\hline $\begin{array}{l}\text { Natural } \\
\text { period of }\end{array}$ & $\begin{array}{l}\text { Period days } \\
\text { in a year }\end{array}$ & $\begin{array}{l}\text { Period days } \\
\text { in a month }\end{array}$ & $\begin{array}{l}\text { Period } \text { ghațīs } \\
\text { in a day }\end{array}$ \\
\hline Moon & 3 & $0 ; 15$ & $0 ; 30$ \\
Mars & 6 & $0 ; 30$ & $1 ; 0$ \\
Mercury & 27 & $2 ; 15$ & $4 ; 30$ \\
Venus & 60 & $5 ; 0$ & $10 ; 0$ \\
Jupiter & 54 & $4 ; 30$ & $9 ; 0$ \\
Sun & 60 & $5 ; 0$ & $10 ; 0$ \\
Saturn & 150 & $12 ; 30$ & $25 ; 0$ \\
Total & 360 & $30 ; 0$ & $60 ; 0$ \\
\hline
\end{tabular}

54 These figures (before the multiplication by 3 ) are the numbers of years assigned to the planets in the 120-year scheme of pre-Islamic nisarga-daśäs; see Bṛhajjātaka 8.9.

55 Literally, 'in the result of the day'.

$5^{6}$ Presumably the time of the daily revolution is meant, rather than the time of sunrise. 
atrodāharaṇam | varṣapraveśe spaștacandrah o|28|16|21 candrarāśíśvaro bhaumo rāśyādiḥ $8|19| 57 \mid 8$ | asyaiva ādyā daśā dinātmikā 6 | atha bhaumabhuktāṃśair $19|57| 8$ bhogyāṃśaiś ca $10|2| 5^{2}$ daśā 6 guṇitā $119|42| 48$ $60|17| 12$ triṃśadbhaktā jātam gatam 3|59|25 gamyaṃ ca 2|o|35 daśāmānam | tatrādau bhaumasya gamyadinādimitā daśā 2|o|35 tato budhasya daśādināni 27 śukrasya 6o guroḥ 54 raveh 6o śaneh 150 | ante bhaumasyaiva gatadivasamitā 3|59|25 daśā | evaṃ māsapraveśe 'pi daśā jñeyā ||

atha naisargikādidaśādivasānāṃ māse dine ca spașțīkaraṇam uktạ̣ tatraiva |

naisargikā ye divasā niruktā gaurīmatān māsaphalārtham atra \|

gataișyamāsāntarasaṃgunās te khāgnyuddhṛtāh spaștatarā bhaveyuḥ | niruktavac cādyadaśāgataișam ādyantayoh syād api tatra māse \| balabhadramatoktānām gaurīvat spaștatā matā| prāgdaśābhuktabhogyaṃ tu kuryād varșadaśoktavat \| naisargikadaśāhānām tadvad eva sphuțīkrtį̣ |

prāgdaśaișagatatvaṃ tu māse kuryān niruktavat || yātaișyadinaviśleșanādikādyanusāratah | sādhyā dinaphale proktakarmaṇā ghațikādaśāh $\|$

dinapraveśe dinapraveśalagnavartamānahaddeśasyādau nisargadaśā tatkrameṇānyeșāṃ daśādināni jñeyāni ||

\footnotetext{
1 spașța] spaștaś K T M \|| 21] 31 G K T M $\quad 2-3$ bhauma] om. B N 357 57 N || bhogyāṃśaiś ... 48] daśā 6 guṇitā 119|42|48 bhogyāṃśaiś ca 10|2|52 guṇitā K T \| 6] om. G 4 6o|17] 6017 N || gataṃ] gatā B N || 3] om. B N || 59] 4|9 M || 25] 35 T p.c. || 35] 25 T 5 gamyadinādi] dinādi B N; gamyādināni K T; gamyādinādi M $\|$ 2|o|35] om. B N \| tato] om. B N 6 6o이 om. N || 150] om. G || bhaumasyaiva] om. B N 7 daśá⿴囗1 ete sthāpyāḥ KTM 8 daśā] vasā B; vaśā G 15 kṛtiḥ] kṛtaḥ B N K T M 17 yātaișya] gataișya K T M 18 prokta] proktā K T M 19 nisarga] vaśād add. K T M
}

10-18 naisargikā ... daśāh] TMṬ 3.17-21 
Here is an example: in an annual revolution, the exact [position of the] moon was $\circ, 28 ; 16,21$; the ruler of the sign of the moon, Mars, was at 8 , $19 ; 57,8$ in signs and so on. The first period belongs to this planet itself and consists of 6 days. Now, the period (6) multiplied by the degrees traversed by Mars $(19 ; 57,8)$ and by the degrees remaining $\left(10 ; 2,5^{2}\right)-119 ; 42,48$ and 6o;17,12, [respectively] - and divided by thirty give a duration of 3;59,25 for the elapsed [part of the] period, and 2;0,35 for the remaining [part]. Of these, the period of Mars comprising its 2;0,35 remaining days and so on [come] first; then the 27 days of the period of Mercury; the 6 o of Venus; the 54 of Jupiter; the 60 of the sun; the 150 of Saturn; and last, the period of Mars itself, comprising its 3;59,25 elapsed days. The periods are to be understood in the same way in a monthly revolution.

Next, how to correct the days of the natural and other periods in [a revolution of] a month or a day is described in the same place [Täjikamuktāvalițippanī 3.17-21]:

For the sake of [applying them to] a monthly figure, ${ }^{57}$ the natural days that have been explained according to the school of Gaurī, multiplied here by the interval between the preceding and following months and divided by thirty, will give very exact [values]; and, as explained [above], the elapsed and remaining [parts] of the first period will be [divided] between the beginning and the end of that month.

The correction of [the periods] described by Balabhadra is considered to be like that of [the periods according to] Gaurī; and one should treat the elapsed and remaining [parts] of the first period like those of the annual periods. The correction of the days of the natural periods is just the same; and one should treat the remaining and elapsed [parts] in a month as explained [above]. In a daily figure, ${ }^{58}$ the periods in ghațis are to be established by the procedure set out [above] in proportion to the difference in $n \bar{a}$ dìs and so on between the preceding and the following day.

In a daily revolution, the first natural period belongs to the ruler of the hadd $\bar{a}$ in which the ascendant of the daily revolution is found; the days of the periods of the other [planets] are to be understood in order [from] that.

57 Literally, 'the result of the month'.

$5^{8}$ Literally, 'the result of the day'. 
atha daśāphalavicāraḥ | tatra daśāphalavicāre viśeșam āha tejaḥsiṃhaḥ |

samyag dhiyābdapadaśādhipayoś ca pūrvaṃ

vācyam phalaṃ tadanu janmakhagānusārāt |

varșodbhavam janibhavam ca daśāvipāka-

kālottham atra ca balatritayam vicāryam \|

sūtau ca varșasamaye 'pi daśâvipāka-

kāle ca yo balayutah sakalāpi tasya |

śreșthā daśā tv aparadrștityutisvadhātu-

sthānādibhedavaśapākaphalenduvīryāt ||

yo janmanìha sabalo vibalo 'bdakāle

tatkālamadhyamabalaś ca daśā tadīya $\mid$

ädye smrtā laghuphalā viphalāparārdhe

jñeyā viparyayaphalā balavaiparītye $\|$

varșe ca janmani balì vibalo vipāke

pāke balī ca vibalah prasavābdakāle |

kālatraye 'pi khalu madhyabalas trayo 'mī

dātuṃ kșamā bahuphalaṃ na ca yogajātam \|

yo vīryavān januși madhyabalaś ca varșe

virryojjhitah śritadaśạ̣ sa dale daśāyāḥ |

pürve tu pürnaphalado 'lpaphalo 'parārdhe

kāryo viparyayavidhir viparītavīrye \|

vīryojjhitas trisamaye bahuduḥkhadāȳ

yāvad balam tu khacarasya phalam ca tāvat |

yāvanty ahāny adhigatah sadrśo balīyāmens

1 viśeșam] viśeșaphalam K T M $\quad$ 4-5 vipākakālottham] vipākam ālokyam B; vipākakālokyam N 5 vicāryam] vimṛśyam G K T M 6 varșasamaye] rṣavasemaye N \|| 'pi] ca G K T M 8 dṛțțiyuti] dṛgviyuti G; dṛșțiyuta K T M 9 sthānādibheda] sthānād abheda B N || vaśa] daśa $\mathrm{G} \quad 10$ sabalo] sakalo $\mathrm{N} \quad 11$ balaś ca] balā ca $\mathrm{B}$; balanva $\mathrm{N} \quad 12$ ādye] ādyas N || viphalā-] om. B a.c. N; śubhaphalālpaphalā B p.c. 13 viparyaya] vipargraya N 14 ca] om. K 16 balas trayo 'mī] balemetrayomī B; balametrayobhī N 17 kșamā] kșamo B 19 vīryojjhitaḥ] vīryohitaḥ B N; vīryoktitaḥ G a.c.; vīryopitā K M; vīryojjhitā T \|| daśaḥ] daśāḥ G; daśā K T M || sa dale] samaye K T M 22 vīryojjhitas] vīryohitas B; vīryohitaya N; vīryositas G a.c. \| trisamaye] tramaye N || dāyī] dāyau K M 23 ca] tu K T M 24 yāvanty] evaṃ tv B; evaṃty N || adhigataḥ] api gataḥ B N || sadṛsśo] sad asau B N

2-5 samyag ... vicāryam] DA 30.1 6-808.1 sūtau ... vīryāt] DA 214-218

16 balas trayo 'mī] B adds sa eva in the margin. 
Next, judging the results of the periods. Concerning the judgement of the results of the periods, Tejahsiṃha states a special rule [in Daivajñālaṃkrti 30.1, 214-218]:

After careful consideration, the results of the ruler of the year and of the ruler of the period should be described first. Thereafter, in accordance with [the placements of] the planets in the nativity, the threefold strength arising from [the revolution of] the year, the nativity, and the time of maturation of the periods should be considered.

If [a planet] is endowed with strength in the nativity as well as at the time of [the revolution of] the year and the time of maturation of its period, its entire period is excellent, bearing fruit according to various [considerations] such as aspects and conjunctions with other [planets], its own nature and placement, [and] by the strength of the moon. If [a planet] is strong in the nativity, weak at the time of the year, and of middling strength at the time of that [period], its period is said to give slight results at the beginning and no results in the latter half. If the [distribution of] strength is the reverse, the results, [too], are understood to be reversed. [If a planet is] strong in the year and in the nativity but weak during the period; strong during the period but weak at the times of the nativity and the year; or of middling strength at all three times, these three [types of period rulers] are unable to give any great results produced by the configurations. If [a planet] is strong in the nativity, of middling strength in the year, and bereft of strength during its period, it gives full results in the former half of its period but slight results in the latter half. If the [distribution of] strength is the reverse, the rule should be reversed. [A planet] bereft of strength at [all] three times gives much suffering: a planet gives as much [good] results as it has strength. As many days as it goes forth thus in strength, 
tāvanti caiva suphalas tu sadābdavīryāt $\|$

ādhāram indujabalam nikhilagrahāṇām

āhur balasya khalu daivavidah purāṇāh |

tasmāc chubhāśsbhaśaśāinkabalādinottham

dadyuh phalam nijadaśāsu śubhāśubham ca | iti |

atha daśāphalavicāre viśeșam āha samarasiṃhạ̣|

varșapatir yo jāto varșadaśāyām ca sa prabhuh kathitaḥ |

nijadhātvanusāravaśāt tasyādeśyam phalaṃ viduṣā ||

tejahsimho 'pi |

varșeśvaro nikhilavarșadaśeśvaro 'tra

prokto balābalavaśena śubhāśubham ca|

dhatte svadhātujaphalam prathamam tato 'tha

samyak trikālajanitam balam asya bodhyam \|

ayam arthah | varṣe varșeśvarasyaiva daśāphalaṃ jñeyam | anyeșāṃ grahāṇāṃ nijadaśāmitair dinair varșeśadaśāyām antardaśāphalaṃ jñeyam | etat spașțam uktam tukajyotirvidbhị |

varșasvāmidaśāntare nijaphalās tābhyo 'pi sūkșmā daśạḥ | iti |

atrāpi yena graheṇa varșeśa itthaśālaṃ karoti tasyaiva phalaṃ pūrṇaṃ jñeyam | anyasya phalaṃ kiṃcin nyūnaṃ jñeyam iti samarasiṃhạ ||

atha sūryādigrahāṇāṃ caturvidhadaśāphalāni tājikasāravāmanoktāni 20 krameṇa likhyante |

1 suphalas] svaphalas B N || sadābda] tābda B N; sa cābda K T M 2 indujabalaṃ] indunavalaṃ K 8 viduṣā] viduṣaḥ K T M 12 dhatte] tedhe N $\quad$ 14-19 anyeșāṃ ... jñeyam²] om. B N 17 tābhyo] tebhyo G 20 sūryādi] daśābhāva B N; sūryādīnāṃ K T M || tājikasāra] tājikasāre K T M

10-13 varșeśvaro ... bodhyam] DA 14.517 varṣa ... daśāḥ] TM 80 
so long does it give good results, always according to [its] strength in the year.

Ancient astrologers state that the strength of the moon is the foundation of the strength of all the planets: therefore, in their respective periods, they will give the good and evil results arising from the strength of the moon for good and evil, and so forth. ${ }^{59}$

Now, [in the Tãjikaśāstra], Samarasiṃha states a special rule for judging the results of a period:

[The planet] that becomes ruler of the year is also declared ruler of the period of the year. The wise should predict its results in accordance with its own nature.

And Tejaḥsiṃha [says in Daivajñālaṃkrti 14.5]:

The ruler of the year is declared ruler of all the periods in this year: according to its strength or weakness it gives the good or evil results arising from its nature. Therefore its strength as produced by the three times should first be fully understood. ${ }^{60}$

The meaning is as follows: in a year, the results of the [major] period should be understood to belong to the ruler of the year itself, while those of the other planets during the days comprising their respective periods should be understood as the results of subperiods within the period of the ruler of the year. This is clearly described by Tuka Jyotirvid [in Tājikamuktāvali 8o]:

They give their own results within the period of the ruler of the year; and there are even more minute periods than these.

And among these, Samarasiṃha says [in the Täjikaśāstra] that only the results of a planet with which the ruler of the year forms an itthaśäla should be understood to be full, while the results of [any] other planet is somewhat less.

Next, the four kinds of results of the periods of the sun and other planets as described in Tājikasāra and by Vāmana are written in order.

59 This last verse is not attested in available independent witnesses of the Daivajñālamkrti.

6o The 'three times' presumably refer to the nativity, the annual revolution, and the point or period in time under investigation. 
gajāśvalābhaṃ balakāntivrddhị̣ karoti bhūpatvam atho sakhitvam | survarnaratnāmbarabhümilābhạ̣ divāpatih pūrnabalo narāṇām || mānodayam grāmapureșu deśe vānijyato vā bahulārthalābham | datte hi dārāsutamitrabhūpaị prītịn nrṇām madhyabalo dineśạ $\|$ svabandhubhir vā svajanair virodhaṃ bhramodayaṃ dīptibalärthanāśam | karoti nūnam svadaśāpraveśe tāpārtikrn naștabalo dineśą̣ || śatror bhayam vā nrpater bhayam ca dhanopaghātam vadhabandhanādyam | karoti rogāgamanam ca śokam balakșayam dagdhabalo dineśạ̣ $\|$ lagnāt trilābhārinabhahsthito 'rko nindyo 'py asāv ardhaphalo daśāyām | yāti tv asau madhyabalah śubhatvam sampūrnavīryo 'tiśubho niruktah ॥

vāmanaḥ|

nִrpatitvaṃ pradhānatvaṃ tejo hastyaśvavāhanam | svadaśāyām phalam caiva datte pürṇabalo ravị̣\| vyāpāram tu puragrāmād dravyalābham sukhāni ca| svadaśāyām phalaṃ caiva datte madhyabalo ravị $\|$ tejobhraṃśạ̣ tathā ghātaṃ naiḥsvyaṃ bāndhavavigraham | svadaśāyām phalam caiva datte nindyabalo ravih \| rogaṃ ghātaṃ bhayam śokaṃ vadhaṃ bandhanam eva ca| nānānarthān mahākleśạ̣ datte naștabalo ravih \|

iti raviḥ |

\footnotetext{
1 lābhaṃ] lābhyam B N 5 bandhubhir vā] baṃdhumitra K T M || bhramodayaṃ] pramodayam B N 8 dhanopa-] janopa- K T M $\|$-ādyam] -ākhyam G $\quad 12$ yāti] pāpi G 15 sva] sta G || pūrṇa] mūdhya B $\quad$ 16-17 vyāpāram ... raviḥ] om. B 17 datte] dhadatte N 18 bāndhava] baṃdhuṣu G K T M 20 rogaṃ] gegam N \|| vadhaṃ bandhanam eva ca] mṛtyuvaṃdhanavigrahau G; bhṛtyavaṃdhanavigrahaih K T; bhṛtyabaṃdhanavigrahaih M 21 kleśaṃ] śokan K T M 22 iti raviḥ] ity arkaḥ K T M

1-12 gajāśva ... niruktaḥ] TS $268-272$

18-21 tejo ... ravih] K T M give these two stanzas in reverse order.
} 


\subsubsection{The Period of the Sun}

[Tājikasāra 268-272 says:]

With full strength, the sun makes gain of elephants and horses, increase in strength and beauty, kingship or friendship [with kings], and gain of gold, jewels, garments and land. With middling strength, the sun gives rise to honours in villages and towns in the land, or gives men abundant gain of wealth from trade and the affection of wives, children, friends and kings. When it has lost its strength, the sun makes conflicts with one's friends or one's own people, ${ }^{61}$ gives rise to error, ${ }^{62}$ makes loss of lustre, strength and wealth and afflicts [the native] with suffering as its period begins. When its strength is burnt away, ${ }^{63}$ the sun makes danger from enemies or danger from the king, injuries to wealth, death, captivity and so on, the onset of illness, grief and loss of strength. Occupying the third, eleventh, sixth or tenth house from the ascendant, the sun, though base [in strength], gives half its [good] results in its period; if it is of middling strength, it becomes good; if of complete strength, it is declared to be exceedingly good.

[And] Vāmana [says]:

With full strength, the sun gives kingship, prominence, vigour, elephants, horses and vehicles as results in its period. With middling strength, the sun gives business, gain of goods from towns and villages and pleasures as results in its period. With base strength, the sun gives loss of vigour, injury, poverty and strife with kinsmen as results in its period. Having lost its strength, the sun gives illness, injury, danger, grief, death and captivity, various reversals and great affliction as results in its period.

This concludes [the results of] the sun.

61 Once more giving bandhu the extended meaning of 'friend' to distinguish it from svajana 'own people, kinsmen'.

62 Or 'wandering'.

63 The sun naturally cannot be 'burnt' in the usual sense, that is, heliacally set; cf. Chapter 5 , note 39 . 
nrpāspadatvaṃ nrpater dhanāptịn śatror vināśam sukham adbhutam ca| strīraupyaśuklämbaramauktikāptim karoti sampūrnabalo mrgān்kah || vānijyato 'rthāgamanam ca loke bhüpatvam annāmbaramitralābham | datte svagehād atulam ca saukhyam dharmodayam madhyabalo mrgāànkah \| vairam svamitrair nijabandhudāraị saukhyārthanāśam prakaroti śīghram | śleșmodayam vātakaphodayam ca kāntikșayaṃ naștabalo mrgāinkah \|

bhikṣātanam kleśavivādavairam dhanapranāśam prakaroti putraị | vairam kaphārtim manasi pramoham rātrišsvaro dagdhabalo narāṇām || lagnāt trivittāyagato 'pi candro nindyo hi dhatte 'rdhaphalam daśāāām | yāti tv asau madhyabalah śubhatvam sampūrnavīryo 'tiśubho niruktah ॥

vāmanah |

padaprāptịn nṛpād räjyam strīläbham sukhasampadam | sthānaprāptim manahsaukhyam datte pūrnabalah śaśî vānijyam saphalam kuryāt svagehe 'pi mahāsukham | jñātiprādhānyam aiśvaryaṃ dadhyān madhyabalaḥ śaśî|| dehe māndyam suhrịdveșam mahāglāniṃ dhanakșayam | mitravairam manastāpaṃ datte 'dhamabalaḥ śaśî || tejohānim mahākleśaṃ śîtajvarakaram param | dauḥsthyam pāpasamācāram kuryān naștabalaḥ śaśī||

iti candrah |

1 ṇ̣pās-] pās- N || dhanāptiṃ] dha priṃ N 4 annā-] atrā- K M 13 dhatte] datte G K T M 16 prāptiṃ] scripsi; prāptir B N G K T M 17 prāptim] s scripsi; prāptir B N G K T M 19 dadhyān] dadyān G K T M $\quad 20$ glāniṃ] mlāniṃ K T $\quad 21$ 'dhama] dhaya N 22 kleśaṃ] leśam $\mathrm{N}$

1-14 nụpās- ... niruktaḥ] TS 273-277

23 dauḥsthyạ̣ ... śaśī] K T M reverse the two quarter-stanzas: kuryān naștabalaś caṃdro dausthyam pāpa (pāpaṃ M) samācaran. 


\subsubsection{The Period of the Moon}

[Tājikasāra $273^{-277}$ says:]

With full strength, the moon makes royal authority, gain of wealth from the king, destruction of enemies, marvellous happiness, and gain of women, silver, white garments and pearls. With middling strength, the moon gives acquisition of wealth from trade, dominion among [common] people, gain of food, garments and friends, incomparable happiness from one's home, and the dawning of piety. When it has lost its strength, the moon quickly brings forth enmity with one's friends, kinsmen and wife, loss of happiness and wealth, the onset of [illness from] rheum, from [the humours of] wind and phlegm, and loss of beauty. When its strength is burnt away, the moon brings forth begging, misery, quarrels and enmity, destruction of wealth, enmity with children, afflictions of phlegm and confusion of mind for men. But if occupying the third, second or eleventh house from the ascendant, a base moon gives half its [good] results in its period; if it is of middling strength, it becomes good; if of complete strength, it is declared to be exceedingly good.

[And] Vāmana [says]:

With full strength, the moon gives attainment of rank from the king, dominion, gain of women, the blessing of happiness, attainment of position and happiness of mind. With middling strength, the moon will make successful trade and great happiness in one's home; it will give prominence among relatives and dominion. With meagre strength, the moon gives illness of body, hatred among friends, great fatigue, loss of wealth, enmity with friends and suffering of mind. Having lost its strength, the moon will make loss of vigour, great affliction causing severe fever with chills, uneasiness and evil habits.

This concludes [the results of] the moon. 
kṣitisutah sabalah prtanādhipam tanubhrtam prakaroti rane jayam | kanakatāmradhanāni dadāty asau vividhasaukhyapadam nrpasamgamam || nrpajanaih kalaho 'vaninandane bhavati madhyabale svabalakșayah | parikaroti tanau rudhirāmayam ripubhayam sutadārabhayam nṛ̣ām \| vivādam khalair vigraham putradārais tathā vairito bhītim ugrāṃ narāṇām | karoty eva bhaumo vinașțo vinaștam phalạ̣ kṛtsnakam cālpasaukhyaṃ nitāntam \| vighäto 'rthanāśạ svabhrtyair virodham mahāsamgare mrtyukaștam svadehe | kuje dagdhavirye svaviryasya nāsám bhayam śatruto raktapīdā narāṇām \| lagnāt trișașthāyagato mahïjo nindyo 'pi so 'rdhah phalado daśāyām | yāti tv asau madhyabalah śubhatvam sampūrnavīryo 'tiśubho niruktah ||

vāmanah |

kujaḥ pūrṇabalo dadyāt saṃgrāme vijayaśriyam | daṇdanāthapadaprāptị senānāyaka eva ca \| madhyavīryạ̣ kujạ̣ kuryāt tejasvitvam jayam rane | räjyatantraṃ sthapatyam ca räjyam cālabhyam eva ca \| hīnaviryah kujạ̣ kuryād bhañgaṃ kleśaṃ mahāgadam | dehe ghātam tu vaikalyam raktasrāvam mukhāt tathā

2 tanubhṛtaṃ] scripsi; tanubhṛtām B N G K T M 3 dadāty] dadaty B N G T; dadanty K $\quad 5$ svabala] sabala K M 9 vinașțo] vinișțo N $\|$ vinaștạm] viniștam N 10 kṛtsnakaṃ] kṛtsnavaṃ K || cālpa] cāntya K 11 'rthanāśaḥ] rtham āśaṃ K 13 svavīryasya] svavīryasva $K$ T || nāśaṃ] nāśo K M 16 yāti] yātis B N || niruktaḥ] nirujạ̣ B 18 vijaya] vijayī B N 19 daṇ̣a ... prāptiḥ] om. B N \| nātha] nāthaḥ G 20 madhya] madhī B 21 tantraṃ] tatra B N || sthapatyạ̣] om. B N || cālabhyam] vā labhyam K T M $\quad 22$ kleśaṃ] krośaṃ G 23 srāvaṃ mukhāt] śrāvasukhāt K T

1-16 kṣiti ... niruktah] TS 278-282 


\subsubsection{The Period of Mars}

[Tājikasāra $278-282$ says:]

Strong, Mars makes a man commander of an army and brings victory in battle; it gives wealth of gold and copper, various kinds of happiness and the company of princes. When Mars is of middling strength, there is quarrel with princes and loss of one's strength; it makes illness of blood in the body, danger from enemies, and dangers to men's wives and children. [Its strength] ruined, Mars ruins every result and makes quarrels with fools, discord with wives and children, terrible danger from enemies, and very little happiness for men. When the strength of Mars is burnt away, there is injury, loss of wealth, conflict with one's servants, evil [equal to] death to one's body in a great battle, loss of one's strength, danger from enemies, and suffering from blood for men. [But] occupying the third, sixth or eleventh house from the ascendant, Mars, though base, gives half its [good] results in its period; if it is of middling strength, it becomes good; if of complete strength, it is declared to be exceedingly good.

[And] Vāmana [says]:

With full strength, Mars will give the glory of victory in battle; [there is] attainment of judicial office, ${ }^{64}$ and [the native is made] commander of an army. With middling strength, Mars will make vigour, victory in battle, [involvement in] politics and government ${ }^{65}$ and [near]unattainable dominion. With little strength, Mars will make defeat, misery, severe illness, injury and mutilation of the body, and effusion

64 Literally, 'the position of lord of the rod'.

65 Or, possibly, 'architecture'. 
vivādaṃ vigraham yuddham jhakațam ca mahābhayam |

svadaśāyām phalam caiva datte naștabalạ̣ kujạ̣ \|

iti bhaumah |

svabuddhito 'rthāgamanam ca rājyam

saukhyam ca hastārjitavittam ugram |

sampūrnavīryānvitasomasūnur

datte vilāsam svajanaiś ca bhṛtyaih $\|$

sadbuddhivṛddhim sutavittaläbham

vidyāvilāsam svajanaiś ca saukhyam |

somātmajo madhyabalo daśāyām

datte hi saukhyam vividhaih prapañcaih $\|$

kaștodayaṃ saukhyabalārthanāśam kịrtikșayaṃ bhītim athārtim ugrām | prāpnoti vairam svajanaiś ca bhrtyair nindye vipāke khalu candrasūnoh $\|$ svajātiduḥham khalu vairam ugram

kuryāe ca lokaịn saha cālpasaukhyam |

vidyārthanāsam kumatịn krśatvam

datte viśeșena budho hi dagdhạ $\|$

tyaktārirandhrāntyagato 'nyato jño nindyo 'pi so 'rdhah phalado daśāyām |

yāti tv asau madhyabalah śubhatvam sampūrnaviryo 'tiśubho niruktah \|

vāmanah |

sevayā sukhasamvvrddhir dhanalābho mahāyaśah |

svabuddhyā rājyalābham ca kuryāt pūrnạabalo budhah $\|$

dharmasiddhim sukarmāptim atulām unnatim tathā |

1 jhakațaṃ] prakațaṃ G; markațam K M $\quad 2$ kujạ̣] bha add. N 4 sva] sad K T M 7 bhṛtyaiḥ] vṛttaih B N 12 kīrti] kīrtta G \|| athārtim] athārtham K M \| ugrām] ugram B N; ugram K T 13 prāpnoti] prāmoti N || nindye] nindyo K T M || sūnoḥ] sūnuḥ K T M 14 duḥkhaṃ] vairaṃ K T M \| khalu] bahu K T M \| vairam] duḥkham K T M 16 kumatim] tiṃ N 18 tyaktāri] tyatkāti G; tyaktvāri K T M \| -āntyagato] -āṃtyam ato G; -āntyam ato K T M || jño] nya B N; jñe K T \|| 'pi] om. N \|| 'rdhah]] rddham K T M 21 sevayā] sevāyā G || saṃvṛddhir] samppatir $\mathrm{G} T$; sampattir $\mathrm{K} M \|$ dhana] dha add. $\mathrm{N} \quad 22$ rājya] gajya $\mathrm{N}$; rāja $\mathrm{K}$ 23-818.1 dharma ... budhạ̣] om. B N 23 siddhiṃ sukarmāptim] siddhis tu karmāptin K; siddhis tu karmāptir T; siddhin tu karmāptim

4-19 sva ... niruktah] TS $283-287$ 
of blood from the mouth. Having lost its strength, Mars gives quarrels, discord, fighting, disputes and grave danger as results in its period.

This concludes [the results of] Mars.

\subsubsection{The Period of Mercury}

[Tājikasāra $283-287$ says:]

Endowed with complete strength, Mercury gives acquisition of wealth through one's own intellect, dominion, happiness, formidable wealth earned by [one's own] hands, and rejoicing with one's own people and servants. With middling strength, Mercury in its period gives increase of good understanding, gain of children and wealth, delight in learning, happiness from one's own people, and pleasures of many varieties. If the period of Mercury is base [in strength, the native] meets with rising evils, destruction of happiness, strength and wealth, loss of renown, danger, cruel pain, and enmity with one's own people and servants. Burnt, Mercury will make suffering from ${ }^{66}$ one's own kin, violent enmity with people [in general] and little happiness, and particularly gives loss of learning and wealth, foolishness and gauntness. [But] occupying any place other than the sixth, eighth or twelfth house, Mercury, though base, gives half its [good] results in its period; if it is of middling strength, it becomes good; if of complete strength, it is declared to be exceedingly good.

[And] Vāmana [says]:

There is increase of happiness through service, gain of wealth and great renown, and with full strength, Mercury will make [the native] gain dominion through his own intellect. With middling strength, Mercury 
paṭhanāl lekhanād räjyaṃ dadyān madhyabalo budhạ̣ $\|$ mānanāśam mahākaștam dhananāśam mahad bhayam | kalim gehe tathākīrtị̣ dadyād dhinabalo budhah \| deśād deśāntaraprāptim ghātam bandhukulakșayam | bandhanaṃ buddhidoșeṇa dadyān nașțabalo budhaḥ \|

iti budhah |

aiśvaryalābhaṃ nrpateś ca mānaṃ kāntyudgamam rājyasamāgamaṃ ca| datte narāṇām sabalah surejyo hemāmbarādyaṃ vividham vilāsam || vyāpārato 'rthāgamanam gurutvam nrpaih suhrttvam sutadārasaukhyam | prāpnoti mitrāmbaradharmalābham vācaspater madhyabalasya pāke \| dāridryaduḥkhaih paripịditāñgaṃ dharmārthanāśaṃ ripujạ̣ bhayạ̣ ca| strīputramitraih kalaham surejyo nașto vinaștam prakaroti sarvam \| duștāmayārtiṃ dhanadharmanāśam ripor bhayaṃ vā nṛpates tathaiva| sukhakșayam mitrasutair virodham karoti dagdhah suraräjapüjyah $\|$ lagnāt șaḍaștāntyabhabhinnasaṃstho nindyo guruś cārdhaphalo daśāyām | 15 yāti tv asau madhyabalah śubhatvam sampūrnaviryo 'tiśubho niruktaḥ \|

vāmanah |

maṇdalasvāmitām tejo narendratvam athāpi vā | dhanam aiśvaryam ārogyam dadyāj jīvo balādhikah \| vijñānaśāstrādhigamam ācāryatvam nrpāàt sukham |

1 lekhanād rājyaṃ] lekhanā dravyan K; lekhanād dravyan T M 2 nāśaṃ²] hāniṃ G; hānim K T 3 kaliṃ] kalir K T \| budhaḥ] yudraḥ N 4 deśād] diśād G \| deśāntaraprāptiṃ] deśāntaraṃ prāptaṃ B N || ghātaṃ] ghātuṃ K T; dhātaṃ M $\quad 5$ naștạ] nișța K T 9 ṇ̛paiḥ] bhūpaiḥ G K T M \|| suhṛttvaṃ] svahṛtvaṃ B N 10 prāpnoti] prāmoti N || pater] patir B N K T M || balasya] balaḥ sva M || pāke] pākeh B N $\quad 11$-āngam]] -āṃgaiḥ B N 13 dușțāmayārtim] s scripsi; duștāmayārtir B N; dușțād bhayārti G; dușțād bhayārtir K T M $\quad 15$ -āntyabha] -āṃtyama K T M 20 -ādhigamam] -ādhikatvaṃ B N || ācāryatvaṃ] dravyalābho B N

7-16 aiśvarya ... niruktah] TS 288-292

2-5 māna ... budhaḥ] K T M give these two stanzas in reverse order. 
will give accomplishment of merit, attainment of good deeds, incomparable elevation, and dominion through reading and writing. With little strength, Mercury will give loss of honour, great evil, loss of wealth, grave danger, domestic discord and infamy. Having lost its strength, Mercury will bring about moving from one country to another, injury, loss of kinsmen and family community, and captivity [caused] by fault of understanding.

This concludes [the results of] Mercury.

\subsubsection{The Period of Jupiter}

[Tājikasāra 288-292 says:]

Strong, Jupiter gives men gain of rulership, honours from the king, increasing beauty, acquisition of dominion and manifold delights such as gold and garments. In the period of Jupiter with middling strength, one meets with acquisition of wealth through business, greatness, ${ }^{67}$ friendship with princes, happiness from wife and children and gain of friends, garments and merit. [Its strength] ruined, Jupiter brings everything to ruin, torments [the native's] body with poverty and suffering, [brings] loss of merit and wealth, danger from enemies, and quarrels with wife, children and friends. Burnt, Jupiter makes affliction from severe illness, loss of wealth and merit, danger from enemies or from the king, loss of happiness and discord with friends and children. [But] occupying any place other than the sixth, eighth and twelfth sign, a base Jupiter gives half its [good] results in its period; if it is of middling strength, it becomes good; if of complete strength, it is declared to be exceedingly good.

[And] Vāmana [says]:

Endowed with strength, Jupiter will give governorship or kingship, vigour, wealth, power and good health. With middling strength, Jupiter will give mastery of sciences and doctrines, the office of preceptor, hap-

67 Or, more specifically, 'the office of a teacher'. 
saukhyaṃ rājyādhikāraṃ ca dadyān madhyabalo guruh $\|$

dehe rogavivrddhim ca dāridryạ̣ dharmavicyutim | parābhavaṃ ripor bhïtiṃ dadyān nyūnabalo gurụ $\|$ dhananāśạ̣ sthānanāśam ādhivyādhisamudbhavam | dantapiḍām karoty eva varșe nașțabalo gurụ $\|$

iti guruh |

rājyam kalatraṃ ca sukhaṃ vilāsaṃ datte dhanaṃ kāñcanabhūpamānam | śukrasya sampūrnabalasya pākah putrodayam mitrasamāgamam ca \| strīpakșato 'rthāgamanam ca saukhyam mișțānnapānam varasundarišs ca | daityādhipo madhyabalo hi dhatte govājicitrāmbaravittalabdhim \| itas tatạ sambhramanam ca pumsām karoti vijñānayaśo'rthanāśam | sahotthamitrātmajakāminībhị̣ kleśam sito naștabalo 'tikaștam \| putrakșatiṃ rogabhayam ca kaștam sukhārthanāśam svajanair virodham | prāpnoti dagdhe bhṛuje nitāntam svamitradārādibhayam ca pumsā̄m || lagnād vyayāștārigrham vihāya

daityādhipaḥ śeșagrhe 'rdhadaḥ syāt | nindyo 'pi madhyah śubhakrn niruktah sampūrnavīryo 'tiśubhapradah syāt $\|$

vāmanaḥ|

rājyam lakșmīm kalatram ca putramitrasubhogyatām | svadaśāyām phalam caiva datte pūrnabalo bhṛuḥ\| daṇdeśaḥ sarvaśāstrajñaḥ svapakṣāc ca mahādhanam | svadaśāyam phalaṃ caiva dadyān madhyabalaḥ sitậ $\|$ bhramaṇaṃ niṣphalā sevā strīpakșād asukham bhavet | svadaśāyām phalam caiva dadyād alpabalaḥ sitậ $\|$

2 rogavivṛddhiṃ ca] rogaṃ manastāpam G K T M \| vivṛddhiṃ] viṿ̛ddhiś B N \| vicyutim] nāśanam K T M 3 parābhavaṃ] parābhavoṃ N 8 pākạ̣] pāke K T M 9 saukhyạ̣ mișțā-] saukhyam iștāā- G || pānaṃ vara] pānāṃvara G K T; pānāṃbara M 10 daityādhipo] dītyādhipo N || dhatte] datte K TM 14 bhṛguje] bhṛgujo G || dārādi] dārāri G 17 madhyaḥ] madhyam B N 18 śubhapradạ̣ syāt] śubhạ̣ purastāt B N $\quad$ 20 rājyaṃ lakșmīṃ] rājalakșmī K T; rājalaksmīṃ M $\|$ subhogyatām] svabhogyatām K T M 21 sva] tad KT $\quad 22$ sva] sa G || mahā] mahad K T M

7-18 rājyam ... syāt] TS 293-297 
piness from the king, pleasures and royal authority. With little strength, Jupiter will give increasing illness in the body, poverty, fall from piety, defeat and danger from enemies. Having lost its strength in the year, Jupiter makes loss of wealth, loss of position, onset of suffering and illness, and toothache.

This concludes [the results of] Jupiter.

\subsubsection{The Period of Venus}

[Tājikasāra 293-297 says:]

The period of Venus complete in strength gives dominion, a wife, happiness, delight, wealth, gold, honour from the king, the birth of a child and the company of friends. With middling strength, Venus gives acquisition of wealth from women, happiness, delicious food and drink, the most beautiful women, and gain of cattle, horses, exquisite garments and riches. Having lost its strength, Venus makes men roam here and there and lose their learning, renown and wealth; [it makes] suffering through siblings, friends, children and wives, and great evil. When Venus is burnt, men meet with injury to their children, dangerous illness, evil, loss of happiness and wealth, discord with their own people, and grave danger to ${ }^{68}$ their friends, wives and so on. [But] occupying any place other than the sixth, eighth and twelfth house, Venus, though base, gives half [its good results; if] middling, it is declared to be good; [if] of complete strength, it will give exceedingly good [results].

[And] Vāmana [says]:

With full strength, Venus gives dominion, riches, a wife and much enjoyment from children and friends as results in its period. [The native becoming] a judge ${ }^{69}$ versed in all sciences, ${ }^{70}$ and great wealth from his own party: with middling strength, Venus will give [these] results in its period. There will be roaming, fruitless service, and unhappiness from women: with little strength, Venus will give [these] results in its period. Having lost its strength, Venus gives grief on account

68 Or, possibly, from.

69 Literally, 'lord of the rod'.

70 Or '[legal] treatises'. 
putraśokaṃ gṛhabhramśaṃ pathi mṛtyum dhanakșayam | svadaśāyām phalam caiva datte naștabalo bhṛuḥ \|

iti bhrguh |

dadāti sampūrnabalo 'rkaputro nīcādhipatyaṃ gajaveśmalabdhim | durgādisaṃsthānam atho sukhāptịn vāsāmnsi navyāni parāñganāptim || kharoștrakośādikadurgarakșām śanaiścaro madhyabalo nitāntam | karoty anarthāgamanam khalatvam sukhārthanāśam svajanair virodham || dhanakșayam caurabhayāribhītim karoti vairam svajanaiś ca mitraih | patangajo naștabalo narāṇām sukham na kiṃcit svadaśāpraveśe || viyogaduḥkhaih paritaptadeham mitrārthanāsam maraṇaṃ prakuryāt | kharāṃśujo dagdhabalo nitāntam duḥkhạ̣ svadāraiḥ svasutair nitāntam \| lagnāt trișașthāyagato 'rkaputro nindyo 'pi so 'py ardhaphalo daśāyām | yāti tv asau madhyabalah śubhatvam sampūrnavīryo 'tiśubho niruktah \|

vāmanah |

ațavyāṃ deśabhūpatvam bhinnadeśādhikāratām | svadaśāyām phalaṃ caiva datte pūrnabalah śanih \| kośaguptiḥ kharoștrānām durgamārgādirakṣaṇam | svadaśāyām phalam caiva datte madhyabalah śanih \| viyogam vigraham vyādhim vikārān maraṇaṃ dhruvam | svadaśāyām phalam caiva dhatte 'dhamabalah śanih $\|$ nīcasevā grhodvegas tathā caurād dhanakșayah | svadaśāyām phalam caiva datte naștabalaḥ śanị̣ ||

iti śaniḥ ||

\footnotetext{
1 śokaṃ] śoko B N 3 bhṛguh] śukra N; śukrah G K T M 4 balo] phalo B N $\quad 5$ saṃsthānam] satsthānam G T M \| vāsāṃsi] vāsāni B N G T 6 kośâdika] śokādika K \| madhya] dhya T 7 khalatvaṃ] khalutvam B N 10 dehaṃ] dehe K M \| mitrārtha] migitrārtha N 15 ațavyāṃ] aṭavī G; ațano K T; ațanaṃ M \| -ādhikāratām] -ādhināthatā G K T M 16-17 sva ... rakṣaṇam] om. B N 19 vikārān] svīkārān M \| maraṇaṃ] marutāṃ K T; maruto M \| dhruvam] mṛtim K T; mṛtim M 20 dhatte] datte K T M
}

4-13 dadāti ... niruktaḥ] TS 298-302

71 Or 'low rulership'. 
of children, eviction from one's home, death on the road and loss of wealth as results in its period.

This concludes [the results of] Venus.

\subsubsection{The Period of Saturn}

[Tājikasāra $298-302$ says:]

With complete strength, Saturn gives rulership over low people, ${ }^{71}$ gain of elephants and dwellings, ${ }^{72}$ residence in forts and the like, gain of happiness, new clothes and gain of others' wives. With middling strength, Saturn makes [the native] guard donkeys and camels, treasuries and forts [but] meet with great reversals: [it makes] foolishness, loss of happiness and goods, and discord with one's own people. Having lost its strength, Saturn makes loss of wealth, danger from robbers and enemies, enmity with friends and one's own people, and no happiness for men at all during its period. When its strength is burnt away, Saturn will torment [the native's] body with the pains of separation and verily bring forth loss of friends and wealth, death, and great suffering through one's own wife and children. [But] occupying the third, sixth or eleventh house from the ascendant, Saturn, though base, gives half its [good] results in its period; if it is of middling strength, it becomes good; if of complete strength, it is declared to be exceedingly good.

[And] Vāmana [says]:

Kingship over a forest region, authority in an alien ${ }^{73}$ land: with full strength, Saturn gives [these] results in its period. Guarding the treasury, protecting donkeys and camels, forts, roads and so on: with middling strength, Saturn gives [these] results in its period. Separation, discord, illness, certain death from disease: with meagre strength, Saturn gives [these] results in its period. Serving the low, unrest at home and loss of wealth due to robbers: having lost its strength, Saturn gives [these] results in its period.

This concludes [the results of] Saturn.

72 Or 'of elephant dwellings'.

73 Or 'a divided'. 
atha lagnadaśāphalam uktaṃ varșatantre |

daśā tanoḥ svāmiphalena tulyaṃ phalaṃ dadātīty aparo viśeșaḥ| care subhā madhyaphalādhamā ca dvimürtibhe 'smäd viparītam ühyam \| aniștam iștam ca samam sthirarkșe kramād drkānaih phalam uktam ādyaị | satsvāmiyogekșanatah śubham syāt pāpekșanāt kașțaphalaṃ ca vācyam \|

hāyanottame'pi |

pürve tribhāge carabhe subhā syān madhyā dvitīye tv adhamā trtit̄ye | sthire tv aniștā prathame tribhāge śubhā dvitīye ca samā tritīye \| pūrve tribhāge dvitanāv aniștā madhyà dvitīye śubhadā tritīye | daśā vilagnasya budhair niruktā jñeyam phalam sveśabhavam tribhedaih || iti |

lagnadaśāviśeșaphalaṃ hillāje |

hemamuktāphaladravyalābham ārogyam uttamam | kurute svāmisanmānaṃ daśā lagnasya cottamā $\|$ lābham kaștena vittasya maitrīhinnasya sevanam | manaso vikrtim yāti daśa madhyā vilagnajā $\mid$ videśagamanaṃ kleśaṃ buddhināśam kalim vyayam | mahāhānim ca kurute kașțā lagnadaśā phalam \| krūralagnadaśämadhye saukhyam svalpam dhanaryayam | dehe dụ̣khaṃ tathā kaștaṃ mātulasya ca jāyate | svāmimitraśubhair drște lagne madhyaphalaṃ bhavet \|

\footnotetext{
1 phalam] valam $G \quad 2$ phalena] valena $G$ p.c. $\quad 3$ śubhā] phalā K T M $\|$ phalā-] śubhā- K T M || 'smād] syād M 5 kramād dṛkāṇaih] kramādaṣkāṇaiḥ N 6 sat] sa B N 8 hāyanottame] hāyanojaye K 9 carabhe] carame K T M 10 tv] ty B N 11 pūrve] pūrvo N \| dvitanāv] dvitamāv G 19 manaso] manasā G K T M \| daśā] dasta K T; danta M \| madhyā] madhya B N M $\quad 20$ vyayam] vyathāṃ K T M $\quad 21$ kașțā] nașțā K T M 22 saukhyam svalpaṃ] svalpasaukhyam $\mathrm{G} \quad 23$ duḥhaṃ] sukhaṃ $\mathrm{G}$

2-7 daśā ... vācyam] VT 17.44-45
} 


\subsubsection{The Period of the Ascendant}

Next, the results of the period of the ascendant are described in Varșatantra [17.44-45]:

The period of the ascendant gives results equal to the result of its ruler: this is another special rule. [The ascendant falling] in a movable [sign, the period is] good, middling, or poor, [respectively]; in a doublebodied sign, the reverse of that is to be inferred; in a fixed sign, [the results are] bad, good, and neutral, [respectively]: in that order did the ancients describe the results by means of the decans. By benefics and its ruler joining or aspecting [the ascendant], there will be good; from malefics aspecting, evil results should be predicted.

And in the Hāyanottama [it is said]:

In the first third-part of a movable sign, [the period] will be good; middling in the second; poor in the third. In a fixed [sign, the period is] bad in the first third-part, good in the second, and neutral in the third. In a double-bodied [sign, the period is] bad in the first third-part; middling in the second; good in the third. [Thus] the learned have explained the period of the ascendant. The results produced by its ruler should be understood through [these] three divisions.

Particular results of the period of the ascendant [are described] in the Hillāja[tājika]:

An excellent period of the ascendant makes gain of gold, pearls and goods, excellent health, and honours from one's master. A middling period of the ascendant tends to gain of wealth with difficulty, serving an unfriendly [master], and disturbance of mind. An evil period of the ascendant makes travel abroad, misery, destruction of reason, quarrels, ruin and great loss its results. During a malefic period of the ascendant, little happiness, loss of wealth, pain in the body and evils to [the native's] maternal uncle ${ }^{74}$ arise; [but] if the ascendant is aspected by its ruler, its friends, and benefics ${ }^{75}$ [it will produce] middling results.

74 Because the ascendant is the eighth house of death and suffering from the sixth house, which in its turn is the third (siblings) from the fourth (mother).

75 Or 'by benefics friendly to its ruler'. 
iti lagnadaśāphalam |

atra grahād varșeśaphalavad daśāphalam ity uktaṃ tejạ̣siṃhena |

varșeśvarasya vișaye dyusadāṃ yad uktam

pūrvam phalaṃ nijadaśāsu tad eva cintyam |

śreșțhạn ca madhyam adhamam ca balānusārāt

samyak tato grahaphalam prathamam vicintyam \|

iti grahānāạm daśāphalāni ||

athāntardaśānayanaṃ varșatantre |

daśāmānam samāmānam prakalpyoktena vartmanā |

antardaśāh sādhanīyāh prāk pātyāmśavaśena ca|

$\bar{a} d \bar{a} v$ antardaśā pākapates tatkramato 'khilāḥ \|

ayam arthah | pūrvaṃ hīnāṃśavaśena pātyāṃśāś ca niṣpāditās tatra pātyāṃśayogena varṣasthānābhiṣiktam daśāmānaṃ bhajet | labdham antardaśānayane dhruvako dinādikaḥ | tena grahapātyāṃśāḥ pūrvavad gomūtrikayā guṇitāḥ șașțopary upari yutā grahasyāntardaśāmānaṃ dinādikaṃ bhavet | tatra prathamato mahādaśāsvāmina evāntardaśā tato likhitakrameṇa tadagrimāntardaśā tatạ̣ sarvādhikāṃśagrahānantaram punar atihīnāṃśakrameṇa mahādaśāsvāmipṛșṭhaparyantam antardaśā jñeyā ||

\footnotetext{
1 daśā] om. B $\quad 2$ atra] atha $\mathrm{K}$ || grahād] grahāṇāṃ G K T M 3 varṣeśvarasya] varșesvaratva G; varșeśvaratva K T M 4 cintyam] vitvam K T 6 phalaṃ] valaṃ G T; balaṃ K M $10 \mathrm{ca}$ ] tu K T M 12 pūrvaṃ hīnā-] pūrvadvīnā- G 14 dinādikaḥ] dinādi B N G || graha] ga B N; om. G 16-17 mahā ... tatah] mahādaśāś cāṃtardaśā tato B N 18 ati] api K T M

3-6 varșe- ... vicintyam] DA 29.9 9-11 daśā ... 'khilāḥ] VT 17.46-47
} 
This concludes the results of the period of the ascendant.

On this matter, Tejahsiṃha says [in Daivajñălamkrti 29.9] that the result [to be expected] from a planet in its period is like the result [when it is] ruler of the year:

The same results that were ascribed to the planets above in the context of ruling the year should be considered [to apply] to their respective periods. Thus, the results of a planet should first be determined as excellent, middling or poor in accordance with its strength.

This concludes the results of the periods of the planets.

\subsection{The Subperiods of the Planets}

Next, the calculation of subperiods [is described] in Varșatantra [17.46-47]:

Taking the duration of the period [of any planet] to be the duration of the year, the subperiods should first be established in the manner described [above], according to the deducted degrees. The subperiod of the ruler of the [major] period [comes] first, [then] all [others] in order from that.

The meaning is as follows: first the deducted degrees are derived from the reduced degrees; then one should divide the duration of the [major] period, assuming ${ }^{76}$ the office of the year, by the sum of the deducted degrees. The quotient is the constant in days and so on for calculating the subperiods. The deducted degrees of a planet, multiplied by that [constant] through the cow's-urine [procedure] as before and increased by any product exceeding sixty, will give the duration of the subperiod of [that] planet in days and so on. Among them, the subperiod of the ruler of the major period itself [comes] first, then the subperiod of [the planet] following it in the order written down; then, directly following the planet with most degrees of all, the subperiods should be understood to continue in order from [the planet] with the fewest degrees, up to [the planet immediately] preceding the ruler of the major period.

76 Literally, 'anointed to'. 
atrodāharaṇam | tatra śukramahādaśā dinādyā 90|42|17 | idam eva daśāmānaṃ varṣasthānābhiṣiktam kalpitam | tatạ̣ sarvapātyāṃśayogena ${ }^{28}{ }^{16} 63^{1}$ prāgvad bhaktaṃ labdho dinādiḥ sarvagrahāṇām antardaśādhruvakaḥ 3|12|28|30 | anena śukrasya pātyāṃśāḥ $7|7| 27$ gunitāḥ șaștyopary upari yutāh jātā dinādyā śukradaśāyām śukrāntardaśā 22|51|13|26 | evaṃ sarveșām apy antardaśāḥ sādhanīyāḥ | evam antardaśābhyo 'pi vidaśāḥ sādhyā ity uktam vāmanena |

antardaśādināni syus tebhyah proktena vartmanā |

sādhyāni vidaśāyāś ca dināni phalasiddhaye |

śubhayogekṣaṇān maitryā tat phalaṃ paricintayet \|

atha grahāṇām antardaśāphalāni tājikasāre |

nrpaprasādam dhanadhānyalābham sukhāgamaṃ mitrasutodayaṃ ca| datte divānāthadaśādhipāke vidhor daśā strīsvajanāt pramodam \| senāpater vā nrpater dhanāptiṃ mitrārthaläbham bahulam sukhaṃ ca | bhānor daśāāām yadi bhūmisūnoḥ karoti raktāmbarabhūmilābham \| sukhārthanāso ripurogabhītir nirudyamatvaṃ vyasanāgamaś ca|

1 daśā dinādyā] daśādimādyā N $\|$ 9o] scripsi; 97 B N G T; 92 K M $\quad 2$ tataḥ] tạ̣ N; tat K T M $\|$ yogena] anena add. K T M 3 bhaktam]] bhūktaṃ K T; bhuktaṃ M 4 7|7|27 $] 2|7| 7$ K; 27|7 M $\quad 5$ 22|51|13|26] 22|21|13 B; 22|2113 N; om. K $\quad 7$ ity] rity K $\quad 8$ syus] syu N $\quad 15$ daśāyāṃ] daśā B || sūnoḥ] sūnuḥ K T M || raktāmbara] riktāmbara K T || bhūmi²] dhānya K T M || lābham] pālaṃ B p.c. 16 -āgamaś] -āgamañ M

12-830.7 nrpa ... vidhatte] TS 307-311

13-14 datte ... ca] These two half-stanzas have been accidentally omitted from TS Mumbayī 1898-1899, causing an irregularity in the numbering of verses. 
Here is an example, as follows: ${ }^{77}$ the major period of Venus in that [figure] in days and so on was 90;42,17. The duration of this very period is taken to assume the office of [the duration of] the year. From that, divided as before by the sum of all deducted degrees $(28 ; 16,31)$, the constant for the subperiods of all the planets in days and so on $(3 ; 12,28,30)$ is derived. The deducted degrees of Venus $(7 ; 7,27)$, multiplied by this [constant] and increased by any product exceeding sixty, give the subperiod of Venus in the period of Venus in days and so on as 22;51,13,26. The subperiods of all [the planets] are to be established in this way. And Vāmana says that the third-level periods are to be established in the same way from the subperiods:

The days of the subperiods will be [derived] from them in the manner described, and the days of the third-level periods, too, should be established for success in [predicting] the results. By benefics joining or aspecting, one should consider that result [to manifest] through friendship.

Next, the results of the subperiods of the planets [are described] in the Tājikasāra.

\subsubsection{Subperiods in the Period of the Sun}

[Tājikasāra 307-311 says:]

The [sub]period of the moon in the ongoing period of the sun gives favour from the king, gain of wealth and grains, attainment of happiness, the appearance of friends and children, and delight through women and one's own people.

If [the subperiod] of Mars [occurs] in the period of the sun, it makes gain of wealth from the commander of an army or from the king, gain of friends and goods, much happiness, and gain of red garments and land.

77 While the values given in this paragraph are internally coherent (accepting the emendation of go whole days for the major period of Venus) and clearly based on the revolution figure introduced in section 7.1 above, they contain a double miscalculation. First, all values except that for the sum of the deducted degrees $(28 ; 16,31)$ appear to have been converted from the 'solar' to the 'civil solar' format. Second, the ratio between the two formats is not the standard one ( $360: 365 ; 15,31,30=1: 1 ; 0,52,35,15)$, but rather $36 \circ: 366 ; 5^{2}$ $=1: 1,8,40$. It is not clear when or how these miscalculations arose. The correct value for the constant in the major period of Venus would be 89;0,25 / 28;16,31 = 3;8,52,20 solar days; that of the Venus subperiod, $3 ; 8,52,20 \times 6 ; 59,27=22 ; 0,22$ solar days, giving 22;19,40 civil solar days. 
kupātradāne sakalārthanāśo budhasya tigmāṃśudaśāvipāke \| hemāsvaläbham sujanāt suhṛttvam strīputrato vā vividham ca saukhyam | divādhināthasya daśāpraveśe jōvasya datte sunrpeña sañgam || vairodayam satpurușān nitāntam dharmārthanāśam vividham ca kaștam | śukrasya ced ghasrapater daśāyām daśā prakuryāt kumatịn krśatvam || kṣucchastrabhūpālabhayam vivādaṃ dehe kṛ́atvaṃ svajaneșu vairam | saurī daśā tīvrakarasya pāke nṛnām prayāty akṣirujaṃ vidhatte \|

atra svadaśāyām svāntardaśāphalaṃ pūrvoktaṃ grahāṇāṃ daśāphalam eva jñeyam | ity arkadaśāyām antardaśāphalam ||

pittāsrarogam svatanau krśatvaṃ

bhüpād bhayam cārthabhayạ̣ virodham |

kuryāa chaśāinkasya daśāivipāke

bhānoh pravișțā tvarato 'rthanāśam ||

sukhārthanāśam nrpater virodham kustrīprasañgaṃ kujanair vivādam |

bhaumasya tārādhipater daśāyām daśā nṛ̣ām dehabhayam krśatvam ||

nānārtharatnāni suvarnaläbham

nijeșțavrddhim priyatām ca loke |

baudhī śaśānkasya daśām praviștā

buddher vivrddhim prakaroti saukhyam \|

\footnotetext{
1 kupātradāne] kuryāt tadānīm K T M $\quad 2$ sujanāt] svajanāt G K T $\quad 5$ śukrasya ced] śukro bhavet G 8 daśāyām svāntar] daśāyāṃtar BN 9 ity ...phalam] om. G \| daśāyām] daśām B N 10 svatanau] svajane K M 13 bhānoḥ] bhāvoḥ G \| tvarato 'rtha] tvarayārtha G K T M 14 sukhārtha] khacārtha B N 16 nānārtharatnāni] yānāśvaratnārtha G K T M 18 śaśāṅkasya] daśāpraveśe add. B N K M \|| daśāṃ] daśā M 19 buddher vivṛddhiṃ] om. B N $\mathrm{K}$

10-832.8 pittāsra ... kașțam] TS312-317
} 
[In the subperiod] of Mercury in the ongoing period of the sun, there is loss of happiness and wealth, danger from enemies and illness, lethargy, the onset of calamity, and complete loss of wealth by donating to an unworthy recipient.

[The subperiod] of Jupiter occurring in the period of the sun gives gain of gold and horses, friendship with good people or manifold happiness from women and children, and the company of a good prince.

If the [sub]period of Venus [occurs] within the period of the sun, it will bring forth the onset of enmity with good men, severe loss of merit and goods, manifold evils, foolishness and gauntness.

The [sub]period of Saturn in the current period of the sun visits danger from hunger, weapons, and the king, disputes, gauntness of body, enmity with one's own people, and disease of the eyes on men.

Here, the results of a planet's own subperiod within its period should be understood to be [identical with] the results of its [major] period described above. This concludes the results of the subperiods in the period of the sun.

\subsubsection{Subperiods in the Period of the Moon}

[Tājikasāra 312-317 says:]

[The subperiod] of the sun occurring in the ongoing period of the moon will quickly bring about disease of bile and blood, gauntness of one's body, danger from the king, dangers to wealth, strife, and loss of wealth.

The [sub]period of Mars in the period of the moon [brings] men loss of happiness and wealth, opposition from the king, attachment to bad women, disputes with bad people, dangers to the body, and gauntness.

[The subperiod] of Mercury occurring in the period of the moon brings forth manifold wealth and jewels, gain of gold, increase of loved ones, ${ }^{78}$ the affection of people [in general], increase of understanding, and happiness.

78 Or 'of desired [objects]'. 
punyodayaṃ brāhmaṇadevabhaktim

nrpād dhanāptịn sutamitrasaukhyam |

datte śaśān்kasya daśāvipāke

prāptā daśā devapurohitasya $\|$

lābhaṃ nṛpād rājajanāt suhṛttvaṃ satputramitrād bahulārthaläbham |

śaukrī daśā candradaśāpraveśe kuryāc charīe paramām ca pușțim \|

svabāndhavair mitrasutaiś ca vairam śatrūdayam kāntibalārthanāśam |

karoti candrasya daśāvipāke daśā hi mandasya kalatrakaștam \|

iti candradaśāyām antardaśāphalam ||

dhanāgamaṃ kāñcanabhūmilābham prapoṣaṇaṃ mitrasutādikānām |

daśā kharāṃśor dharaṇisutasya daśāpraveśe prakaroti saukhyam || hiraṇyanārīrajatārthalābham karoti saukhyaṃ vijayaṃ ripūṇām | tārādhināthasya daśā prayātā bhaumasya pāke tu śubhā narānāām || asadvyayam mitrasutair virodhaṃ bhayam ripūṇām asukhaṃ narānāam | karoti bhaumasya daśāvipāke śaśān்kasūnor vividham ca kașțam \| sukhārthanāśạn nijamitrakaștạ̣ karoti nūnam svajanair virodham | kubhojanaṃ bhūmisutasya pāke daśā prapannā surapūjitasya $\|$ khalair vivādam svajanair virodham rogodayam rājabhayaṃ ripūnām | karoti śukrasya daśā daśāyāṃ kujasya kaștam bahulaṃ narānām \| cakṣuhprapị̂ạ̄m prakaroti puṃsām pāpāsrarukśatrubhayam kṣitīśāt | saurī daśā bhümisutasya pāke yadi prayātā svajanair virodham \|

iti bhaumadaśāyām antardaśāphalam ||

3 vipāke] praveśe G K T M 8 daśā²] pāko K T M \| kașțam] kașțe B 11 kharāṃśor] rāṃśo N || praveśe] vipāke K T M 13 śubhā narāṇām] śubhānurāgaṃ G K T M 16 kașțaṃ] om. N 17 kubhojanaṃ] na bhojanaṃ G 19 daśāyāṃ] praveśe K T M 20 pāpāsra] pāpāṣ̣ K T $\quad 21$ prayātā] prayā G 22 bhauma ... phalam] bhaumah K T M

10-21 dhanā ... virodham] TS $318-323$

10-838.19 dhanā ... bhogān] The individual stanzas in the passages quoted here are given in a different order than in independent witnesses of the TS (namely, from the sun to Saturn as opposed to the actual order of subperiods within each major period). 
The [sub]period of Jupiter occurring in the ongoing period of the moon gives a dawning of piety, devotion to gods and Brahmans, gain of wealth from the king, and happiness from children and friends.

The [sub]period of Venus occurring in the period of the moon will make gains from the king, friendship with princes, abundant gain of wealth from good children and friends, and excellent bodily well-being.

The [sub]period of Saturn in the ongoing period of the moon makes enmity with one's kinsmen, friends and children, the rise of enemies, loss of beauty, strength and wealth, and evils to one's wife.

This concludes the results of the subperiods in the period of the moon.

\subsubsection{Subperiods in the Period of Mars}

[Tājikasāra 318-323 says:]

The [sub]period of the sun occurring in the period of Mars brings forth acquisition of wealth, gain of gold and land, the support of friends, children and so on, and happiness.

The [sub]period of the moon occurring in the period of Mars is good for men and brings forth gain of gold, women, silver and wealth, happiness and victory over enemies.

[The subperiod] of Mercury in the ongoing period of Mars makes bad losses, discord with friends and children, danger from enemies, unhappiness and manifold evils for men.

The [sub]period of Jupiter occurring in the period of Mars makes loss of happiness and wealth, evils to ${ }^{79}$ one's friends, discord with one's own people, and bad food.

The [sub]period of Venus in the period of Mars makes disputes with fools, discord with one's own people, onset of illness, danger from the king [and from] enemies, and abundant evils for men.

The [sub]period of Saturn, if occurring in the period of Mars, brings men affliction of the eyes, danger from evil [men], blood disease, and enemies, [danger] from the king, and discord with one's own people.

This concludes the results of the subperiods in the period of Mars.

79 Or, possibly, from. 
nānārthalābham prakaroti puṃsāṃ lābhaṃ kṣitīsáàt svajanāc ca saukhyam | prāptā hi sūryasya daśā daśāyām saumyasya nityam vividham vilāsam \| kaștam śarīre nijabandhuvairam saukhyārthanāśam ca bhayam kșitissāât | vātavyathām somadaśā prapannā cāndrer daśāyām prakaroti nityam \| vraṇodayaṃ dadruvicarcikārtim sukhārthahāniṃ bahulaṃ ca kaștam | karoti saumyasya daśāvipāke daśä hi bhaumasya parair vivādam \| ārogyatāṃ sādhujaneșu saukhyaṃ bhogān vicitrān dvijadevasevām | daśā yadā devaguroh prayātā cāndrer daśāyām prakaroti mānam \| raupyāmbarasthānacatușpadānām

lābham ca saukhyam bahulaṃ vilāsam | śaukrī daśā saumyadaśāvipāke prāptā pratișthām prakaroti puṃsām \| vātārtikrt kaștam analparogam kānter vināśam nrpater bhayaṃ ca| saumyasya pāke yadi sūryasūnor daśā prayātā bahuvittanāśam ||

iti budhadaśāyām antardaśāphalam ||

strīputramitrair vividhaṃ vilāsaṃ prapūjanaṃ devagurudvijānām | śatror vināśam prakaroti bhānor daśā prayātā ca guror daśāyām \| mānikyamuktāphalahemalābhaṃ saukhyāni datte vividhāni pumsām | cāndrī daśä jīvadaśāvipāke sarvārthalābham vipulaṃ nitāntam ||

\footnotetext{
1 nānārtha] mānārtha G K T M \| kṣitîsāt] kṣitit N 4 soma] caṃdra G K T M || cāndrer] cāṃdrī B N $\quad 5$ hāniṃ] nāśaṃ G K T $\quad 6$ vivādam] vivāde B N $\quad 7$ vicitrān] viveśan B N 8 guroḥ] guruḥ N || cāndrer] cāṃdrī B N 10 bahulaṃ] vividhaṃ G K T M 12 pratișțhāṃ] praviștām B N 13 ca] vā G 15 budha ... phalam] budhaḥ K T M 18 lābhaṃ] bhaṃlā N

1-14 nānārtha ... nāśam] TS 324-329 16-836.10 strī ... ca] TS 330-335
} 


\subsubsection{Subperiods in the Period of Mercury}

[Tājikasāra 324-329 says:]

The [sub]period of the sun occurring in the period of Mercury brings men gain of various goods, gains from the king and happiness from one's own people, and constant and manifold delights.

The [sub]period of the moon occurring in the period of Mercury always brings forth evils to the body, enmity with one's kinsmen, loss of happiness and wealth, danger from the king and disturbance of [the humour of] wind.

The [sub]period of Mars in the ongoing period of Mercury gives rise to wounds, makes suffering from skin disease and rashes, loss of happiness and wealth, abundant evils and disputes with strangers. ${ }^{80}$

When the [sub]period of Jupiter occurs in the the period of Mercury, it brings forth good health, happiness among good people, various pleasures, service to gods and Brahmans, and honour.

The [sub]period of Venus occurring in the ongoing period of Mercury brings men gain of silver, garments, position and quadrupeds, abundant happiness, delight and eminence.

If the [sub]period of Saturn occurs in the period of Mercury, it makes suffering from [the humour of] wind, [makes] evils, no little illness, loss of beauty, danger from the king and much loss of wealth.

This concludes the results of the subperiods in the period of Mercury.

\subsubsection{Subperiods in the Period of Jupiter}

[Tājikasāra 330-335 says:]

The [sub]period of the sun occurring in the period of Jupiter brings forth manifold delights with women, children and friends, veneration of gods, teachers and Brahmans, and destruction of enemies.

The [sub]period of the moon in the ongoing period of Jupiter gives men gain of rubies, pearls and gold, manifold pleasures, and certain and abundant gain of all [kinds of] wealth.

8o Or 'with enemies'. 
mānam nṛpād rājajanāt suhrttvam ripor vināśam prakaroti lābham | vittasya bhaumasya daśā daśāyāṃ guror narānāạm bahulam sukhạ̣ ca \| yaśahprañāśạn svajanair virodham karoti mithyākalaham svadāraiḥ| śaśān்aputrasya daśā prayātā guror daśāyām tv asukham ca kaștam || vātodayam vātakaphodayam ca dharmārthanāśam ripurogabhìtim| bhrgor daśā jōvadaśāvipāke nrṇām vidhatte nrpater bhayam ca \| parair virodham bahulam ca kaștam kaphodayam dharmadhanakșayam ca | saurī daśā jīvadaśāvipāke nrṇām vidhatte nrpater bhayam ca ||

iti gurudaśāyām antardaśāphalam ||

duștād bhayaṃ bhümipater bhayam vā pittodayaṃ dehabalārthanāśam | bhānor daśä daityaguror daśāyām nụnāạn vidhatte paramam ca kaștam || svalpārthalābham kaphaśîtapīdām svamitraputraị svajanaiś ca dāraiḥ| kleśaṃ ca datte bhrgujasya pāke daśā ca tārādhipateh pramoham \| veśyānurāgam ca vipakṣabhïtim vātāsrarugdharmadhanakșayaṃ ca| daśā ca bhaumasya bhṛor daśāyām prāptā ca pumsā̄m na sukhaṃ kadācit || sadbuddhivrddhim dvijadevabhaktim vidyāvinodam prabhutām ca kīrtim | lābham ca śukrasya daśām prayātā baudhì daśā strïjanitaṃ ca saukhyam \| hiraṇyaratnāmbarabhojanāni lābhaṃ nrpāt satpuruṣaị suhṛttvam | śaukrịn daśāṃ devapurohitasya daśā prapannā prakaroti saukhyam \|

2 daśā] om. B N || bahulaṃ] ca balaṃ G 4 putrasya] sutasya B N 6 nụpater bhayạ̣ ca] subahupralābham B N 12 vā] ca G K T M \| pittodayam] pittot yam N 14 putraị̣] dāraih G; dārais K T M \| dāraiḥ] putraiḥ G K T M 15 daśā ca] prayāti B N \| pramoham] pramodam B N 16 veśyā-] vaiśyā- B N 19 prāptā] prāptaṃ B N 20 vṛddhị̣] bṛdbaddhi N || prabhutāṃ] pramutāṃ B; prabhuvāṃ $N \quad 21$ daśāṃ prayātā] daśāpraveśe G T M; pravetsa K $\quad 22$ ratnā-] vastrā- G K T M \| bhojanāni] bhojanānāṃ G K T M \| nṛpāt sat] nṛpālāt M 23 śaukrīṃ daśāṃ] śaukryāṃ yadā G; pāke bhṛgor K T M || saukhyam] om. T 23-838.1 saukhyam ... prakaroti] om. K M

12-838.2 dușțād ... ca] TS 336-341 
The [sub]period of Mars in the period of Jupiter brings men honour from the king, friendship with princes, destruction of enemies, gain of wealth, and abundant happiness.

The [sub]period of Mercury occurring in the period of Jupiter destroys renown, makes discord with one's own people and useless quarrels with one's wife, unhappiness and evils.

The [sub]period of Venus in the ongoing period of Jupiter brings an excess of [the humour of] wind or excess of [the combined humours of] wind and phlegm, loss of merit and goods, danger from enemies and illness, and danger from the king.

The [sub]period of Saturn in the ongoing period of Jupiter brings men discord with strangers, ${ }^{81}$ abundant evils, excess of phlegm, loss of virtue and wealth, and danger from the king.

This concludes the results of the subperiods in the period of Jupiter.

\subsubsection{Subperiods in the Period of Venus}

[Tājikasāra 336-341 says:]

The [sub]period of the sun in the period of Venus brings men danger from villains or danger from the king, excess of bile, loss of bodily strength and wealth, and the greatest evils.

The [sub]period of the moon in the period of Venus gives little gain of wealth, suffering from phlegm and cold, distress from one's friends, children, wife and own people, and bewilderment.

The [sub]period of Mars occurring in the period of Venus [brings] men attachment to prostitutes, danger from enemies, diseases of [the humour of] wind and of blood, loss of piety and wealth, and never any happiness.

The [sub]period of Mercury occurring in the period of Venus [gives] increase of good understanding, devotion to Brahmans and gods, delight in learning, lordship, renown, gain and happiness from women.

The [sub]period of Jupiter occurring in the period of Venus brings forth gold, jewels, garment, [good] food, gains from the king, friendship with good men, and happiness.

$81 \quad$ Or 'with enemies'. 
droham svavargeșu parair vinodam sukhārthalābham prakaroti puṃsām | pramādanidrākalahaṃ daśāyāṃ śukrasya māndī mahadīśatāṃ ca ||

iti śukradaśāyām antardaśāphalam ||

kleśaṃ pravāsaṃ bhayam iștahāniṃ karoti vairam sutamitradāraị |

bhānor daśá bhānubhuvo daśāyāṃ karoti pị̂ām paramām śarīre \|

kaștena lābham tv asukham ca māndyam

hṛdrogaduhkham vividham karoti |

àlasyanidrābhayam ugravairam

cāndrī daśā bhāskarajasya pāke \|

kleśāgamạ̣ saukhyadhanārthanāśam

kudharmasiddhim paśuputrahānim |

kaujī daśā sūryasutasya pāke

karoti vairam nijabandhumitraih $\|$

sukhārthaläbhaṃ nijamitraputraiḥ prītị vidhatte vividham vilāsam |

mandasya pāke śaśinandanasya daśā narāṇāṃ nrpasaṃamam ca \|

dharmānurāgạ̣ vijayaṃ ripūnāṃ nṛpaprasādaṃ bahulạ̣ ca lābham |

saurer daśāyām dhișaṇasya yātā daśā sukhārthāgamanam karoti \| surārcanaṃ brāhmaṇadevabhaktim sukhārthaläbham nṛateh suhṛttvam | śaukrī daśā sūryasutasya pāke karoti putrān vividhāṃś ca bhogān \|

iti śanidaśāyām antardaśāphalam ||

\begin{abstract}
1 parair] parir N 2 nidrā] vidrāṣ N 5 bhānor daśā bhānubhuvo daśāyāṃ] śanir ddaśāyāṃ ca raver ddaśā yadā G; śaner daśāyāñ ca raver daśāyāṃla K; śaner daśāyāñ ca raver daśāyāṃ T M || karoti] prayāti B N 6 asukhaṃ] carmā add. N 9 bhāskarajasya] bhās$\begin{array}{llll}\text { karaputra G K T M } 13 \text { karoti] rogo 'ti G } 14 \text { mitraputraih] putramitraih G K T } & 15\end{array}$ nandanasya] naṃdasya G 16 ripūṇāṃ] narāṇāṃ K T M $\quad 17$ saurer] saurir B N \|| yātā] jātā G K T M || daśā sukhārthāgamanaṃ karoti] sukhārthalābhaṃ prakaroty avaśyaṃ B N 19 putrān] puṃsām K T M 2o śanidaśāyām] śanāv K T M
\end{abstract}

4-19 kleśaṃ ... bhogān] TS 342-347 
[The subperiod] of Saturn in the period of Venus brings forth treachery to one's own people and delighting with strangers, ${ }^{82}$ gain of happiness and wealth, intoxication, sleep, quarrels, and great power for men.

This concludes the results of the subperiods in the period of Venus.

\subsubsection{Subperiods in the Period of Saturn}

[Tājikasāra 342-347 says:]

The [sub]period of the sun in the period of Saturn makes misery, living abroad, danger, loss of loved ones and enmity with children, friends and wife; it makes severe suffering in the body.

The [sub]period of the moon in the period of Saturn makes gain with hardship, unhappiness, weakness, manifold sufferings from heart disease, lethargy, sleep, fear and terrible enmity.

The [sub]period of Mars in the period of Saturn makes the onset of misery, loss of happiness, wealth and goods, accomplishment of evil rites, ${ }^{83}$ loss of cattle and children, and enmity with one's kinsmen and friends.

The [sub]period of Mercury in the period of Saturn brings men gain of happiness and wealth, the affection of one's friends and children, manifold delights and the company of princes.

The [sub]period of Jupiter occurring in the period of Saturn makes attachment to piety, victory over enemies, favour from the king, abundant gain and acquisition of wealth and happiness.

The [sub]period of Venus in the period of Saturn makes worship of deities, devotion to Brahmans and gods, gain of happiness and wealth, friendship of the king, [birth of] children and manifold pleasures.

This concludes the results of the subperiods in the period of Saturn.

$82 \quad$ Or 'with enemies'.

83 Or, more generally, 'bad [religious] practices'. 
atra lagneśasyāntardaśāphalam eva lagnadaśāntardaśāphalaṃ jñeyam iti | atra śubhāśubhasūcakāntardaśā vāmanenoktāḥ |

candrārajīiā budhajīvaśukrā divākarendū ravijajñaśukrāḥ|

ravīnduśukrā budhajīvamandā jōvajñaśukrā ravitaḥ kramāt syụ̣ \|

evam antardaśāyāś ca pācakāḥ śubhadā grahāh |

anye tv aśubhadā jñeyā evaṃ ca vidaśāphalam || iti |

atha gaurīmatadaśānayanaṃ mahādevamatena ca daśānayanam uktạ̣ muktāvalyām |

janmanakṣatrataḥ proktā daśā gaurīmatāhvayā |

sūryendukujarāhvïjyaśanijñaśikhibhārgavāḥ \|

daśeśā vahnibhājjñeyāḥ kramāt trị̣ parivartanāt |

syur daśādivasās teșāṃ dhṛtis triṃśatimūrchanāh ||

vedeșavo nāgayugā munyarthāh kșitisāyakāh |

mūrchanāh șașțir etebhyo dvādaśāmsśena māsajāh |

șadamiśatulyās tv etāsāṃ nādikā dyuphale daśāḥ \|

athavā rudranakșatrāt tritribhir bhair daśeśvarāḥ |

1 atra] atha $\mathrm{K} \mathrm{T} \quad 2$ atra] atha $\mathrm{K} \mathrm{T} \quad 5^{-6}$ daśāyāś ... vidaśā] om. B N $\quad 7$ matadaśā-] matatena daśā T; matā- $M \|$ mahādeva] yahāyeva B N 10 śikhi] śaśi M 12 mūrchanāḥ] bhūrddanāḥ G 13 yugā] kṛtā G K T M \|| munyarthāḥ] munyakșā KT || sāyakāḥ] śāyakāḥ K T 14 mūrchanāḥ] mūrddanā G 15 nāḍikā dyuphale] nāḍikādyā phalaṃ K T; nāḍikādyāḥ phalam M

9-842.1 janma ... bhāṣitam] TM 82-86

7 ca] At this point K T M add the following text which, from the testimony of G, seems likely to have migrated from the table given shortly below: gaurīmata (-matā K T) daśa janmarkṣamāsadināni dine șadạnśā daśa jũeyā varșe dvādaśāṃśo māsah (|| add. M) mahādevamate ārdrātaḥ $3\left(\|_{3}|| \mathrm{M}\right)$ varșe daśādināni saurāṇi (śaurāṇi $\left.\mathrm{K} \mathrm{T}\right)$ dinapraveśe daśā (om. K T) ghațirūpā te ca. 


\subsubsection{Subperiods in the Period of the Ascendant}

Concerning this, the results of subperiods in the period of the ascendant should be understood to be [identical to] the results of subperiods [in the period] of the ruler of the ascendant itself. On this matter, Vāmana describes which subperiods indicate good or evil results:

In order from the sun there are the moon, Mars and Jupiter; Mercury, Jupiter and Venus; the sun and moon; Saturn, Mercury and Venus; the sun, moon and Venus; Mercury, Jupiter and Saturn; and Jupiter, Mercury and Venus. These are the planets that give good [results] when running their subperiods [in the respective major period]. The others should be understood to give evil [results]. The results of third-level periods [with respect to subperiods] are the same. ${ }^{84}$

\subsection{Periods according to the Schools of Gaurī and Mahādeva}

Next, the calculation of periods according to the school of Gauri and the calculation of periods according to the school of Mahādeva is explained in [Tājika]muktāvali [82-86, Tājikamuktāvalițippaṇī 3.5-7]:

The periods declared from the asterism in the nativity are called the school of Gaurī. The sun, the moon, Mars, Rāhu, Jupiter, Saturn, Mercury, Ketu and Venus should be known as the rulers of the periods in order, thrice repeated, from the asterism of Agni. ${ }^{85}$ The days of their periods are eighteen, thirty, twenty-one, fifty-four, forty-eight, fiftyseven, fifty-one, twenty-one and sixty. The periods of the months are one twelfth of these; those for a figure of the day ${ }^{86}$ equal a sixth of these in $n \bar{a} d \bar{c} s$. Or else, these same [planets] become rulers of periods

84 The order is the usual one of the days of the week. In other words, in the major period of the sun, the good subperiods are those of the moon, Mars and Jupiter; in the major period of the moon, those of Mercury, Jupiter and Venus; etc.

85 That is, Kṛttikā.

86 Literally, 'in the result of the day'. 
eta evam bhavantīti mahādevena bhāsitam \|

gaurimatoktasya daśākramasya daśādimā yā bhavaśād upetā|

sā bhuktabhogyarkșaghațīvinighnā sarvarkșanāḍ̂̀viḥrtā dinādyam \|

dvidhā yad āptam tv iha bhogyajam yat tasya grahasyaiva likhed adhastāt |

daśāpramānam parato grahānām yathāstham agre 'pi likhed adho 'dhah \|

prānte punar bhuktaghațīsamuttham dinādyam ādyasya likhet khagasya | iti |

\section{grahāḥ nakṣatrāṇi}

\begin{tabular}{|c|c|c|c|c|c|c|c|}
\hline$s \bar{u}$ & $\mathrm{kr}$ & $\mathrm{u}$ & $\mathrm{u}$ & $\bar{a} 3$ & 18 & $1 \|$ & 3 \\
\hline cam & ro & ha & śra & $\bar{a} 3$ & 30 & $2 \|$ & 5 \\
\hline mam & $m r$ & ci & dha & $\mathrm{u}_{3}$ & 21 & $1 \|$ & $3 \|$ \\
\hline rā & $\bar{a}$ & svā & śa & svā3 & 54 & $4 \|$ & 9 \\
\hline bṛ & $\mathrm{pu}$ & vi & $\mathrm{pu}$ & jye3 & 48 & 4 & 8 \\
\hline śa & $\mathrm{pu}$ & $\mathrm{a}$ & $\mathrm{u}$ & $\mathrm{u}_{3}$ & 57 & $4 \|$ & $9 \|$ \\
\hline bu & $\bar{a}$ & jye & re & śa3 & $5^{1}$ & $4 \mid$ & $8 \|$ \\
\hline ke & $\mathrm{ma}$ & mū & $\mathrm{a}$ & re3 & 21 & $1 \|$ & $3 \|$ \\
\hline \multirow[t]{2}{*}{ śu } & $\mathrm{p} \overline{\mathrm{u}}$ & pū & bha & krr3 & $6 o$ & 5 & 10 \\
\hline & & & 27 & & 360 & 30 & 60 \\
\hline
\end{tabular}

udāharaṇam | kasyāpi rohinị janmanakṣatram | sā rohinī candrādhaḥsthā | atah prathamavarșe candrasya daśā dvitīyavarșe bhaumasya tṛtīyavarșe rāhor daśā | evam agre 'pi jñeyam | athāsya janmani rohiṇinakṣatrasya bhuktaghațikāḥ 40 bhogyaghațikāḥ 20 | tatrāṣțamavarṣapraveśe śukradaśā

1 eta] etā B N; ete K M \| evaṃ] savaṃ N; eva G K T M \| bhāṣitam] atha add. K T M 2 daśādimā] daśādibhā $\mathrm{G} \quad 3$ sarvarkṣa] sarkṣā N $\quad 4$ yad āptaṃ] nadāsaṃ B; tadāsaṃ N $\quad 5$ parato grahāṇāṃ] cayadignibhāṇāṃ B; cayadignimāṇāṃ N || likhed] likhid G 7 grahāḥ] graha B; gra G; gaurīmatād daśeśvarāḥ add. G || nakṣatrāṇi] nakșatra B; bhā G; nakșatra nakșatra nakṣatra K T; nakșatrāṇi nakșatrāṇi add. M 16 kṛ̂] mā add. B; bha mahādevamate ārdrātas tribhāni add. G; mahādevamatena add. K T M 17 27] janmavarṣe māsadīnarkṣāṇi dine șaḍaṃśāḥ daśā jñeyā add. G \| 36o] varṣe daśādināni saurāṇi add. G; yogaḥ add. K; yoga add. T; yogah 39o M \| 3o] māsapraveśe daśādināni add. G; yogaḥ add. K T M || 6o] dinapraveśe daśādināni add. G; yogaḥ add. K T; yogaḥ zo M 19 daśā] dṛśā B 20 nakṣatrasya] nakșatraya $\mathrm{N}$

2-6 gaurī ... khagasya] TMṬ 3.5-7

7 grahāh] The following table is omitted by N. The abbreviations employed by B G K T M have been preserved for reasons of space. 
[beginning] with every three asterisms [reckoned] from the asterism of Rudra: ${ }^{77}$ that [method] is stated by Mahādeva.

The period that, on the basis of the asterisms, comes first in the order of periods described in the school of Gaurī, is multiplied by the elapsed and remaining ghatisis in [the moon's course through] the asterism and divided by all the nādis of the asterism. Of the twofold result in days and so on, that derived from the remaining [part] should be written down under that same planet as the duration of its period. Thereafter one should write down [the periods] of the planets as they follow in order, one after another; and lastly, one should write down the days and so on of the first planet as produced by the elapsed ghațis.

\begin{tabular}{|c|c|c|c|c|c|c|c|}
\hline \multirow{2}{*}{$\begin{array}{l}\text { Planets } \\
\mathrm{Su}\end{array}$} & \multicolumn{3}{|c|}{ Asterisms } & \multirow{2}{*}{$\begin{array}{l}\text { [Group] } \\
\bar{A}{ }_{3}\end{array}$} & \multirow{2}{*}{$\begin{array}{l}\text { [days in } \\
\text { a year] }\end{array}$} & \multirow{2}{*}{$\begin{array}{l}\text { [days in } \\
\text { a month] }\end{array}$} & \multirow{2}{*}{$\begin{array}{l}{[\text { ghațis }} \\
\text { in a day] } \\
3\end{array}$} \\
\hline & $\mathrm{Kr}$ & UPh & UA & & & & \\
\hline Mo & Ro & $\mathrm{Ha}$ & Śr & Aś3 & 30 & $21 / 2$ & 5 \\
\hline $\mathrm{Ma}$ & $\mathrm{Mr}$ & $\mathrm{Ci}$ & $\mathrm{Dh}$ & $\mathrm{UPh}_{3}$ & 21 & $13 / 4$ & $3^{1 / 2}$ \\
\hline Rā & $\bar{A} r$ & Sv & Śa & Svā3 & 54 & $4^{1 / 2}$ & 9 \\
\hline $\mathrm{Ju}$ & Pn & $\mathrm{Vi}$ & $\mathrm{PBh}$ & Jye 3 & 48 & 4 & 8 \\
\hline $\mathrm{Sa}$ & Pṣ & An & UBh & $\mathrm{UA}_{3}$ & 57 & $4^{3 / 4}$ & $9^{1 / 2}$ \\
\hline $\mathrm{Me}$ & $\bar{A}{ }^{\prime}$ & Jy & $\operatorname{Re}$ & Śa3 & $5^{1}$ & $4^{1 / 4}$ & $81 / 2$ \\
\hline $\mathrm{Ke}$ & $\mathrm{Ma}$ & Mū & Aś & $\operatorname{Re} 3$ & 21 & $13 / 4$ & $3^{1 / 2}$ \\
\hline $\mathrm{Ve}$ & $\mathrm{PPh}$ & $\mathrm{PA}$ & $\mathrm{Bh}$ & Krra & $6 o$ & 5 & 10 \\
\hline [Sum] & & 27 & & & 360 & 30 & $6 o$ \\
\hline
\end{tabular}

An example: someone was born under the asterism Rohinī. That Rohinī is found under [the rulership of] the moon. Therefore, in his first year, [he first had] the period of the moon; in his second year, that of Mars; in his third year, the period of Rāhu; and it should be understood in the same way for the following [years]. Now, in his nativity, the asterism Rohinī had 40 ghațis elapsed and 20 ghațis remaining. At the revolution of his eighth year,

87 That is, Ārdrā. 
jātā | tasyā dināni 6o bhuktaghațībhiḥ 40 guṇitāni 2400 sarvarkṣaghațī- 6o bhaktāni 40 jātāni śukradaśābhuktadināni | atha daśādināni 6o bhogya20 guṇāni 1200 sarvarkṣaghațī- 6o bhaktāni 20 jātāni śukradaśāyā bhogyadināni | tatrāșțamavarṣe ādau śukradaśā bhogyadinamitā 20 tato raveh 18 tataś candrasya 30 bhaumasya 21 rāhoh 54 guroh 48 śaneh 57 jñasya $5^{1}$ ketoḥ 21 | punaḥ prānte śukrasya daśā bhuktadinamitā 40 jñeyā ||

atra gaurīmatadaśā mahādevamatadaśā balarāmamatadaśā ca māsapraveśe māsapraveśanakșatrāj jñeyā | dinapraveśe dinapraveśaspașțalagnanakṣatrāj jñeyā | yathā meșe trayodaśāṃśavimśatikalāparyantam aśvinīnakṣatram evaṃ sarvatra jñeyam | asyā eva nāmāntaraṃ muddadaśeti | muddadaśānayane sugamopāyo miśrakṛtạ̣ |

janmarkṣasaṃkhyāsahitā gatābdā drgūnitā nandahṛtāvaśeșāḥ| ācaṃkurājiśabukeśupūrvā grahā daśeśāh syur ihābdamadhye \|

atrāntardaśāḥ sugamopāyena muddagranthe uktāḥ |

vedā nāgāḥ śarāḥ sapta digrasāñkaṃ śarā rasāḥ|

sūryādīnām ca guṇakās tair nighnā svadaśämitị $\|$

șaștyāptāntardaśā tasya jāyate 'tiparisphuțā |

yasya varșaṃ bhavet tasya prathamā ca daśä bhavet \|

anyās tadagrimasthānād evam antardaśā api

pāpavarșe bhaved duḥkhaṃ śubhavarșaṃ sukhāptaye || iti |

1 dināni] dinā G $\quad 1-2$ bhukta ... 6o] om. K M 1 ghațîbhị̣] ghați G; ghațī T || 40] ghațī

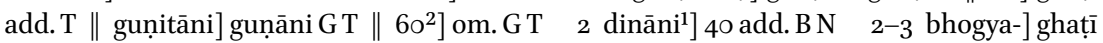
add. K M $\quad 32^{2}$ ] om. K M \|| daśāyā] daśā K T M $\quad 3-4$ bhogya] om. K T M 6 śukrasya śukra K M $\quad 7$ daśá⿴囗十 om. K T M 8 praveśa ${ }^{1}$ ] dina add. G K T M 10 evaṃ] eva K T M ॥ sarvatra] sarva B N; om. K T M || nāmāntaraṃ] nāyātaraṃ B $\quad 12$ gatābdā] gabdā B 14 mudda] madgala B; mudgala N $\quad$ 16-18 mitih ... daśā] om. G 18 varṣaṃ] scripsi; varṣe B N K T M

88 A pleonastic compound, as Arabic mudda itself means 'period'. It is not clear why this system, unmistakably derived from the popular viṃśottarì daśa of classical Indian astrology rather than from Perso-Arabic sources, should be thus designated.

89 Muddagrantha may or may not be intended as the proper name of a work; see the Introduction. The verses quoted often seem garbled and missing words, including the names of planets, while other planets are mentioned twice. Balabhadra addresses the issue of missing names at the end of the section (7.9.9).

90 These multipliers are curious in that they are not derived from the major periods. The generic method of calculating subperiods would produce, for the subperiod of the 
then, the period of Venus commenced. Its 6o days, multiplied by the 40 elapsed ghațis [to make] 2400 and divided by all 60 ghațis of the asterism, give 40 elapsed days of the period of Venus. Next, the 6o days of the period [of Venus], multiplied by the 20 remaining [ ghațis to make] 1200 and divided by all 6o ghațis of the asterism, give 20 remaining days of the period of Venus. In his eighth year, then, the period of Venus is first, comprising the 20 days of the remaining [ghatiss]; then 10 [days] for the sun, then 30 for the moon, 21 for Mars, 54 for Rāhu, 48 for Jupiter, 57 for Saturn, $5_{1}$ for Mercury, 21 for Ketu; and last, the period of Venus should be understood [to recur], comprising the 40 days of the elapsed [ghațis].

Concerning this, in a monthly revolution, the periods according to the school of Gaurī, the school of Mahādeva, and the school of Balarāma are to be known from the asterism [occupied by the moon] in the monthly revolution; [but] in a daily revolution, they are to be known from the asterism on the exact [degree of the] ascendant in the daily revolution, so that the asterism Aśvinī extends up to thirteen degrees twenty minutes in Aries: it should be understood in this way in all cases. Another name for this same [type of period] is a mudda period. ${ }^{88}$ An easy method for calculating mudda periods was devised by Miśra:

The elapsed years [of life] being added to the number of the asterism of the nativity [reckoned from Aśvinī], less by two, and divided by nine, the remainder will give the planet ruling the period in a year, in the order su[n], mo[on], Ma[rs], Rā[hu],Ju[piter], Sa[turn], Me[rcury], $\mathrm{Ke}[\mathrm{tu}], \mathrm{Ve}[\mathrm{nus}]$.

Here are the subperiods, [calculated] by an easy method described in a book on muddas: 89

Four, eight, five, seven, ten, six, nine, five and six are the multipliers of [the planets] beginning with the sun. The duration of each period, multiplied by them and divided by sixty, gives a most exact [duration of the] subperiod of that [planet whose multiplier it is]. ${ }^{90}$ The first period will belong to that [planet] whose year it is; the others follow from that. The subperiods are the same. In the year of a malefic there will be suffering, [but] the year of a benefic tends to happiness.

moon in the major period of the sun, $18 \times 30 / 360=1.5$ solar 'days'; but the method presented here gives $18 \times 8 / 6 \mathrm{o}=2.4 \mathrm{such}$ 'days'. The relative proportions of the subperiods thus differ from those of the major periods. 
atha gaurīmatadaśāsu grahānām antardaśācakram |

\begin{tabular}{|c|c|c|c|c|c|c|c|c|}
\hline 18 & 48 & 69 & 123 & 171 & 228 & 279 & 300 & 360 \\
\hline $4 \mathrm{gu}$ & $8 \mathrm{gu}$ & $5 \mathrm{gu}$ & $7 \mathrm{gu}$ & $10 \mathrm{gu}$ & $6 \mathrm{gu}$ & $9 \mathrm{gu}$ & $5 \mathrm{gu}$ & $6 \mathrm{gu}$ \\
\hline sù 18 & cam 30 & mam 21 & rā 54 & bṛ 48 & śa 57 & bu $5^{1}$ & ke 21 & śu 60 \\
\hline$s \bar{u}$ & cam & maṃ & rā & bṛ & śa & $\mathrm{bu}$ & ke & śu \\
\hline $1 \mid 12$ & $4 \mid 0$ & $1 \mid 45$ & $6 \mid 18$ & $8 \mid \mathrm{o}$ & $5 \mid 42$ & $7 \mid 39$ & $1 \mid 45$ & $6 \mid \mathrm{o}$ \\
\hline caṃ & mam & rā & bṛ & śa & $\mathrm{bu}$ & ke & śu & $s \bar{u}$ \\
\hline $2 \mid 24$ & $2 \mid 30$ & $2 \mid 27$ & $9 \mid \mathrm{O}$ & $4 \mid 48$ & $8 \mid 33$ & $4 \mid 15$ & $2 \mid 6$ & $4 \mid 0$ \\
\hline mam & rā & bṛ & śa & $\mathrm{bu}$ & ke & śu & $s \bar{u}$ & cam \\
\hline $1 \mid 30$ & $3 \mid 30$ & $3 \mid 30$ & $5 \mid 24$ & $7 \mid 12$ & $4 \mid 45$ & $5 \mid 6$ & $1 \mid 24$ & $8 \mid \mathrm{o}$ \\
\hline rā & bṛ & śa & $\mathrm{bu}$ & ke & śu & $s \bar{u}$ & caṃ & maṃ \\
\hline $2 \mid 6$ & $5 \mid \mathrm{O}$ & $2 \mid 6$ & $8 \mid 6$ & $4 \mid 0$ & $5 \mid 42$ & $3 \mid 24$ & $2 \mid 48$ & $5 \mid \mathrm{o}$ \\
\hline bṛ & śa & bu & ke & śu & $s \bar{u}$ & cam & maṃ & rā \\
\hline $3 \mid 0$ & $3 \mid 0$ & $3 \mid 9$ & $4 \mid 30$ & $4 \mid 48$ & $3 \mid 48$ & $6 \mid 48$ & $1 \mid 45$ & $7 \mid 0$ \\
\hline śa & $\mathrm{bu}$ & ke & śu & $s \bar{u}$ & cam & maṃ & rā & bṛ \\
\hline $1 \mid 48$ & $4 \mid 30$ & $1 \mid 45$ & $5 \mid 24$ & $3 \mid 12$ & $7 \mid 36$ & $4 \mid 15$ & $2 \mid 27$ & $10 \mid 0$ \\
\hline bu & ke & śu & sū & caṃ & mam & rā & bṛ & śa \\
\hline $2 \mid 42$ & $2 \mid 30$ & $2 \mid 6$ & $3 \mid 36$ & $6 \mid 24$ & $4 \mid 45$ & $5 \mid 57$ & $3 \mid 30$ & $6 \mid \mathrm{o}$ \\
\hline ke & śu & $s \bar{u}$ & caṃ & maṃ & rā & bṛ & śa & bu \\
\hline $1 \mid 30$ & $3 \mid 0$ & $1 \mid 24$ & $7 \mid 12$ & $4 \mid 0$ & $6 \mid 39$ & $\left.8\right|_{30}$ & $2 \mid 6$ & $9 \mid \mathrm{O}$ \\
\hline śu & $s \bar{u}$ & caṃ & maṃ & rā & bṛ & śa & bu & ke \\
\hline $1 \mid 48$ & $2 \mid O$ & $2 \mid 48$ & $4 \mid 30$ & $5 \mid 36$ & $9 \mid 30$ & $5 \mid 6$ & $3 \mid 9$ & $5 \mid 0$ \\
\hline
\end{tabular}

1 atha ... cakram] om. B G; yogah add. K T M 2 48] 40 M || 171] 174 K T M $\|$ 36o] yogah add. G; 39o M 36 gu$^{2}$ ] dṛ guṇa kah G 4 rā] śa G 6 1|12] 1|19 G \|| 4|o] 4 10 B || 6|18] 6|10 T M || 7|39] 39 B; 7|69 M || 1|45²] 1|48 M 7 śu] śa B G 8 2|24] śa 24 B || 2|27] 242 B || 4|15] 45 B || 4|o] 4000 T M 9 rā] maṃ B || caṃ] om. B 10 5|24] 5|54 B G || 7|12] 1|12 B || 4|45] 5|45 G; 4|15 K M; 4|14 T || 5|6] 86 B || 1|24] 1|4 B; ||24 M || 8|o] om. B 11 br ] rā B || ke] śu ke add. B || maṃ] om. B $\left.12{ }^{2} \mid 6^{1}\right] 3 \mid 6$ B; $2 \mid 26$ G || 4|o] 8|42 4|o add. B || 2|48]

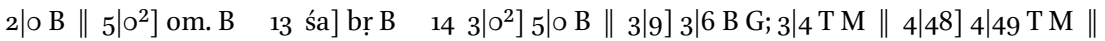
6|48] 2|48 B $15 \mathrm{bu}$ ] śa B $16{ }_{4 \mid 30}$ 3|o B || 3|12] 3|1 B || 7|36] 6|24 K T M 17 ke] bu B || sū] om. B || br] gu G 18 2|30] 3|20 T M || 2|6] om. B 19 śu] ke B $203 \mid$ o] 3100 KT M ॥ 4|o] 4|ı T M || 6|39] 6|49 K T M || 8|30] 8|37 B; 8|20 K T M 21 śu] śu add. B 22 5|36] $4|10 \mathrm{~K} \mathrm{~T} \mathrm{M} \| 5| \mathrm{o}] 8 \mid \mathrm{o} \mathrm{B}$

1 cakram] The following table is omitted by N. The abbreviations employed by B G K T M have been preserved for reasons of space and standardized. K T M merge the first and third rows and omit all but the last occurrences of $g u$ in the second row. 
This is a table of the subperiods of the planets in the periods according to the school of Gaurī: 91

\begin{tabular}{|c|c|c|c|c|c|c|c|c|}
\hline Su 18 & Mo 30 & Ma 21 & Rā 54 & Ju 48 & Sa 57 & $\operatorname{Me} 5^{1}$ & $\operatorname{Ke} 21$ & Ve 60 \\
\hline 18 & 48 & 69 & 123 & 171 & 228 & 279 & 300 & 360 \\
\hline 4 & 8 & 5 & 7 & 10 & 6 & 9 & 5 & 6 \\
\hline $\mathrm{Su}$ & Mo & $\mathrm{Ma}$ & Rā & $\mathrm{Ju}$ & $\mathrm{Sa}$ & $\mathrm{Me}$ & $\mathrm{Ke}$ & $\mathrm{Ve}$ \\
\hline $1 ; 12$ & $4 ; 0$ & $1 ; 45$ & $6 ; 18$ & 8;0 & $5 ; 42$ & $7 ; 39$ & $1 ; 45$ & $6 ; 0$ \\
\hline Мo & $\mathrm{Ma}$ & Rā & $\mathrm{Ju}$ & $\mathrm{Sa}$ & $\mathrm{Me}$ & $\mathrm{Ke}$ & Ve & $\mathrm{Su}$ \\
\hline $2 ; 24$ & $2 ; 30$ & $2 ; 27$ & 9;0 & $4 ; 48$ & $8 ; 33$ & $4 ; 15$ & $2 ; 6$ & $4 ; 0$ \\
\hline Мa & $\mathrm{Ra}$ & $\mathrm{Ju}$ & $\mathrm{Sa}$ & $\mathrm{Me}$ & $\mathrm{Ke}$ & Ve & $\mathrm{Su}$ & Mo \\
\hline $1 ; 30$ & $3 ; 30$ & $3 ; 30$ & $5 ; 24$ & $7 ; 12$ & $4 ; 45$ & $5 ; 6$ & $1 ; 24$ & $8 ; 0$ \\
\hline Rā & $\mathrm{Ju}$ & $\mathrm{Sa}$ & $\mathrm{Me}$ & $\mathrm{Ke}$ & $\mathrm{Ve}$ & $\mathrm{Su}$ & Mo & $\mathrm{Ma}$ \\
\hline $2 ; 6$ & $5 ; 0$ & $2 ; 6$ & $8 ; 6$ & $4 ; 0$ & $5 ; 42$ & $3 ; 24$ & $2 ; 48$ & $5 ; 0$ \\
\hline $\mathrm{Ju}$ & $\mathrm{Sa}$ & $\mathrm{Me}$ & $\mathrm{Ke}$ & $\mathrm{Ve}$ & $\mathrm{Su}$ & Mo & $\mathrm{Ma}$ & Rā \\
\hline $3 ; 0$ & $3 ; 0$ & $3 ; 9$ & $4 ; 30$ & $4 ; 48$ & $3 ; 48$ & $6 ; 48$ & $1 ; 45$ & $7 ; 0$ \\
\hline Sa & $\mathrm{Me}$ & $\mathrm{Ke}$ & $\mathrm{Ve}$ & $\mathrm{Su}$ & Mo & Ma & Rā & $\mathrm{Ju}$ \\
\hline $1 ; 48$ & $4 ; 30$ & $1 ; 45$ & $5 ; 24$ & $3 ; 12$ & $7 ; 36$ & $4 ; 15$ & $2 ; 27$ & $10 ; 0$ \\
\hline $\mathrm{Me}$ & $\mathrm{Ke}$ & $\mathrm{Ve}$ & $\mathrm{Su}$ & Mo & Ma & Rā & $\mathrm{Ju}$ & $\mathrm{Sa}$ \\
\hline $2 ; 42$ & $2 ; 30$ & $2 ; 6$ & $3 ; 36$ & $6 ; 24$ & $4 ; 45$ & $5 ; 57$ & $3 ; 30$ & $6 ; 0$ \\
\hline $\mathrm{Ke}$ & $\mathrm{Ve}$ & $\mathrm{Su}$ & Mo & Мa & Rā & $\mathrm{Ju}$ & $\mathrm{Sa}$ & $\mathrm{Me}$ \\
\hline $1 ; 30$ & $3 ; 0$ & $1 ; 24$ & $7 ; 12$ & 4;0 & $6 ; 39$ & $8 ; 30$ & $2 ; 6$ & 9;0 \\
\hline $\mathrm{Ve}$ & $\mathrm{Su}$ & Mo & $\mathrm{Ma}$ & Rā & $\mathrm{Ju}$ & $\mathrm{Sa}$ & $\mathrm{Me}$ & $\mathrm{Ke}$ \\
\hline $1 ; 48$ & $2 ; 0$ & $2 ; 48$ & $4 ; 30$ & $5 ; 36$ & $9 ; 30$ & $5 ; 6$ & $3 ; 9$ & $5 ; 0$ \\
\hline
\end{tabular}

91 The first three rows of this table have been reordered so as to clarify its internal logic, and now represent the major periods with their duration in days; the total of days in a year elapsed at the end of each period (assuming the year to begin with the period of the sun); and the multipliers used to calculate subperiods. The remaining rows in each column give the rulers of the subperiods in order, each immediately followed by it duration in days and ghațiss. 
atha sūryādīnāṃ daśāntardaśāphalaṃ tatraiva |

sūrye rājakulād bhïtịh pịdā syāt pittasambhavā | vipattayaś ca bandhūnāṃ vittānāṃ vyaya eva ca || śāntiṃ ripupratāpānām nairujyaṃ dhanasampadam | kurute 'ntargataś candro daśāyām caṇdarocișah \| kujo vijayam atyugram hemaratnam nrpāt sukham | cāndriḥ śatrukulād bhītịn kușthapāmādikān gadān | dāridryapāparyasanam rogebhyo 'pi paricyutih \| vilāsam vividham dharmakriyātatparamānasam | pittajvaram ca rogādīn dehatyāgam ca bhārgavaḥ \| mātrpitṛhayam caiva vittānām vyaya eva ca śanir nrpād bhayam dainyam vairivrddhị̣ dhanakșayam || arthanāśo 'nyadeśeșu gamanam gauravālpatā| śatrurājakulād bhïtir anartho bahudhā bhavet ||

cāndryām strīsutabhülābho vastrābharaṇasaṃyutaḥ| svapakșavairam kanyāyā janma nidrāratis tathā $\|$ indor daśāyām mārtaṇde vijayārogyasampadạ̣| bhaume caurāt kośanāśo raktapittādikān gadān $\|$ candraje vittaturagaläbho vittasukhāni ca | dhanālaṃkārahastyaśvam akasmāt surapūjite \| strīsukham ca susañgaṃ ca śukre 'laṃkāralabdhayaḥ | rogavyasanaśokāś ca bandhuto 'bhibhavah śanau \|

3-5 vipattayaś ... caṇụaro-] om. B N 5 'ntargataś] rgataś G \| -ciṣah] -viṣah B 6 vijayam ] vijajayam B; vijayajam N || hemaratnaṃ] hemanalaṃ B N 7 bhītiṃ] bhītam G || pāmādikān] pāpādikān B N \|| gadān] ādān KT 8 dāridryapāpa] dāridratayāya B N 9 vividhaṃ] sacivaṃ B N G || mānasam] mānavaṃ B N 10 jvaraṃ] dvāraṃ B N G 11 mātṛ ... ca] om. B N G 15 ravimudda] navadikṣu B N 16 lābho] lābha B N \| saṃyutaḥ] saṃyutaṃ K T; saṃyutam M 19 gadān] ādān $N \quad 20$ sukhāni] sutāni B N 21 hastyaśvam] hastaścam B; hastāśvam K M 22 susañgạ̣] susammaṃ $\mathrm{G}$ 
Next, the results of the periods and subperiods of the sun and other [planets are described] in the same [work]:

\subsubsection{The Period of the Sun and Its Subperiods}

In [the period of] the sun there will be danger from a princely family and suffering caused by bile, misfortune to kinsmen and loss of wealth. Entering the period of the sun, [the subperiod of] the moon alleviates the torments of enemies, makes good health and the blessing of wealth. Mars [makes] brutal victory, [gain of] gold and jewels, and happiness from the king; Mercury, danger from enemy families, disease such as leprosy and scabies, poverty, evil passions and ruin from illnesses; Venus, manifold delights, a mind attached to [performing] religious rituals, bilious fever, illness and so on, and leaving the body; Saturn, danger to [the native's] mother and father, loss of assets, danger from the king, wretchedness, increase of enemies and loss of wealth. [In the subperiods of Rāhu and Ketu], there will be loss of wealth, travel to other countries, little respect, danger from enemies and princely families, and reversals of many kinds.

This concludes the results of the mudda of the sun.

\subsubsection{The Period of the Moon and Its Subperiods}

In [the period] of the moon there is gain of women, children and land, along with clothes and ornaments, enmity with one's own party, the birth of a daughter and fondness for sleep. In [the subperiod of] the sun in the period of the moon, there is victory, good health and riches; in [that of] Mars, loss of treasure due to robbers, [and the native suffers] illnesses of blood, bile and so on; in [that of] Mercury, there is gain of riches and horses, and pleasures of riches; in [that of] Jupiter, sudden [gain of] wealth, ornaments, elephants and horses; in [that of] Venus, happiness from women, good company and gain of ornaments; in [that of] Saturn, illness, passion and grief, and defeat by kinsmen; [in that of 
vahniśokabhayam ghoram bandhüdvegam dhanakșayam |

śriyo läbham striyo hāniṃ ketāv antargate vidhoh \|

iti candramuddam $\|$

bhaume śatruvimardaś ca vigraho bāndhavaih saha |

raktapittakrtā pịdā parastrībhị samāgamah \|

bhānau bhaumadaśāntaḥsthe pracandaḥ sāhasījayī |

candre sukham suhṛdvrddhir manimauktikasamcayah \|

budhe pittabhavā pị̣̂ā nāśo vairibhayam mahat |

gurau bhūpatimitratvam suhṛttvāsaktacittatā $\|$

śukre raṇād bhayaṃ vyādhivyasanāni dhanakșayaḥ |

śanau dine dine duhkham asahyaryasanāgamam \|

karmārthanāśam udvegạ̣ bandhuvairādikam bhayam |

svanāśo dehapīdā ca ketāv antargate kuje \|

iti kujamuddam ||

baudhyām bandhusamāyogo mitradharmasamāgamaḥ|

prītir janasya vipulā dehapị̄ā tridoșajā $\|$

cāndrer daśāyām uṣnāmenśau dantisvarnāmbarāptayạ̣|

candre vicarcikākuștharājarogādikam bhayam \|

bhaume kleśah śirorogo bandhuvairam mahad bhayam |

gurau rogādibhiryukto bhrgau rājyasugandhimān |

śanau pāpasukhāsaktah pracaṇdo madanoddhatah $\|$

2 śriyo] striyo G K T; striyā M $\|$ striyo] striyā M \| vidhoh] vidhau B 6 bhauma] ma N \| daśāntaḥsthe] daśāṃtastham B N 8 pittabhavā] pittodbhavā K T M 10 dhana] dhanañ KT 11 dine $^{2}$ ] om. BN 12 udvegaṃ] udvege B N \| vairādikaṃ] scripsi; caurādikaṃ B N G p.c.; cairādikaṃ G a.c.; caurādikam K T M 13 svanāśo] svanāśaṃ B N G 14 kuja] caṃdra B || muddam] gṛhaṃ B p.c. N 16 prītir] bhītir B N \|| vipulā] vipulo B N 17 uṣnāṃśau] uṣnāṃśor K T M \|| svarṇāmbarāptayaḥ] svarṇāburāśayaḥ B; svarṇāṃburāśayah N 19 rogo] rogaṃ B N G 21 sukhāsaktaḥ] mukhāsaktaḥ B N 
Rāhu], fire, grief and terrible danger, agitation from kinsmen, and loss of wealth; and with [the subperiod of] Ketu entering [the period of] the moon, [it makes] gain of glory [but] loss of a woman. ${ }^{92}$

This concludes the mudda of the moon.

\subsubsection{The Period of Mars and Its Subperiods}

In [the period of] Mars there is combat with enemies, discord with kinsmen, suffering caused by blood and bile, and relations with others' wives. When [the subperiod of] the sun enters the period of Mars, [the native is] fierce, violent, victorious; in [the subperiod of] the moon, there is happiness, increase of friends and accumulation of jewels and pearls; in [that of] Mercury, suffering caused by bile, ruin, and great danger from enemies; in [that of] Jupiter, friendship with princes and a mind attached to friendship; in [that of] Venus, danger from battle, illness and misfortunes, ${ }^{93}$ and loss of wealth; in [that of] Saturn, suffering day after day, and the onset of intolerable misfortune; [in that of Rāhu], loss of work and wealth, agitation, and danger from enmity with kinsmen and so on; and when [the subperiod of] Ketu enters [the period of] Mars, self-destruction and suffering of body.

This concludes the mudda of Mars.

\subsubsection{The Period of Mercury and Its Subperiods}

In [the period] of Mercury there is a coming together with kinsmen, the pious company of friends, abundant affection from people [in general, but] bodily suffering caused by the three humours. In [the subperiod of] the sun in the period of Mercury there is gain of elephants, gold and garments; in [that of] the moon, danger of rashes, leprosy, consumption and so on; in [that of] Mars, misery, disease of the head, enmity with kinsmen and grave danger; in [that of] Jupiter, [the native] is beset with illness and so on; in [that of] Venus, he enjoys dominion and perfumes; ${ }^{94}$ in [that of] Saturn, he is attached to evil pleasures, violent and

92 Or 'of one's wife'.

93 Or 'passions'.

94 Intended meaning somewhat uncertain. 
bandhunāśo manastāpo dehatyāgo dhanakșayaḥ|

suhribandhusutair dvandvah ketau mitrakalir bhavet \|

iti budhamuddam $\|$

jairyām mānadhanaprāptir devabrāhmanapūjanam |

karnarogas tathā vairam svajanaiś ca kalir bhavet \|

sukhī gurukșemavāmśs ca sūrye jīvadaśāṃngate |

candre bahuvidhā labdhir nirjitärir mahīsute \|

śüropasevī candậs ca paritāpī sukhī kuje |

pitror bhaktih suhrdyukto niruk sukhayuto budhe \|

śukre cintāhṛtih śatrubrāhmaṇāśrayajīvanam|

parānganādisaṃsaktậ śanau sukhadhanojjhitaḥ \|

bandhudveșo mrșāvādaḥ svāmitas tu nirāśrayaḥ \|

iti gurumuddam $\|$

śaukryām strīsaṃgamo lābho vastrābharanasamyutah |

kauśalyam mahatī kìrtir dhanalābhaś ca jāyate \|

ravau sitadaśāntahsthe bandhanam codarāmayah |

kāmalam maulidaśananakharogāh kalānidhau \|

bhaume hy upadravo bhümināśă pittarujo 'sraruk|

2 dvandvah] scripsi; dvaṃdvau B N G; dvandvo KT M \| kalir] valir G 3 muddam] muhạ̣ N 4 jaivyāṃ] jaișțhyām K; jyaișthyāṃ $\mathrm{M} \quad 8$ śūropasevī] śūroyasevā B; śūrovyasevā N; śūropi sevī K T M || paritāpī] paritāpāṃ B N 10 hṛtị̣] haviḥ B N || brāhmaṇāśraya] brāhmaṇāmś copa B N 11 saṃsaktaḥ] saṃskāraḥ B N G \| dhanojjhitaḥ] dhanair hatah K T M 12 svāmitas] svāmibhis K T M 16 bandhanaṃ codarāmayah] budhe netrodarā B N; budhe netrodarāmayaḥ G 17 mauli] bhauli N 18 nāśaḥ pittarujo 'sraruk] nāśayitā ujosṛyukmayaḥ B; nāśayitā ujosūyukmayạ̣ N 
intoxicated by lust; [in that of Rāhu], there is loss of kinsmen, suffering of mind, leaving the body and loss of wealth; in [that of] Ketu, there is strife with friends, kinsmen and children, and quarrel with companions.

This concludes the mudda of Mercury.

\subsubsection{The Period of Jupiter and Its Subperiods}

In [the period] of Jupiter, there will be gain of honour and wealth, veneration of gods and Brahmans, [but] also ear disease, enmity, and quarrel with one's own people. When [the subperiod of] the sun enters the period of Jupiter, [the native is] happy and enjoys prosperity through teachers; in [the subperiod of] the moon, there is gain of many kinds; in [that of] Mars, he defeats his enemies; he serves heroes, is fierce and cruel [but] happy in [the subperiod of] Mars; ${ }^{95}$ in [that of] Mercury there is devotion to parents, [the native is] accompanied by friends, in good health and happy; in [that of] Venus there is onset of anxiety and depending on inimical Brahmans ${ }^{96}$ for a living; in [that of] Saturn, he is involved with others' wives and so on, bereft of happiness and wealth; [in that of Rāhu and Ketu?], there is enmity with kinsmen, lying, and no support from one's master.

This concludes the mudda of Jupiter.

\subsubsection{The Period of Venus and Its Subperiods}

In [the period] of Venus, there is the company of women, gain [of women] along with clothes and ornaments, prosperity, great renown, and gain of wealth. When [the subperiod of] the sun enters the period of Venus, there is captivity and ailment of the stomach; in [the subperiod of] the moon, jaundice and diseases of the head, teeth and nails; in [that of] Mars, calamity, loss of land, illnesses of bile and illness of

95 Mars thus gets a double mention in this list.

96 Or, less likely, 'on enemies and Brahmans'. 
budhe dhanarddhir bhüläbhạ̣ sukhavitteștaläbhakah \|

jōve dhanasukham deśasampattį̣ síladharmakau |

vrddhānganāratị saure ripusaumyādhikāritā $\mid$

mrtir bhayakrtam śokam dụ̣khaprāptir na saṃśayah |

agnidāho jvaro ghorạ̣ kanyājanma striyāś cyutih \|

iti śukramuddam $\|$

śānaiścaryāṃ dehapiẹā putradāraiś ca vigrahaḥ| tandrā śramo buddhināśs videśagamanam bhavet || putrārthamitrastrīnāso daśāyām bhāskare phalam | strīhatam bandhuviśleșah kalir mrtyuh sudhākare \| bhaume duḥkham rujo deśatyāgo bahuvidhersyatā | budhe sukham subhagatā satkāro vijayo dhanam || j̄̄ंe samucitạn saukhyam puragrāmaganeśatā | anekakāminimitram yaśo vittāni bhārgave \| bandhüdvegam mahāduḥham arthanāśo mahad bhayam | agnidāho jvaro ghoraḥ kanyājanmānganāsukham ||

iti śanimuddam $\|$

svarbhānau jāyate dụ̣khaṃ bandhūnām ātmano rujạ̣| deśāntareșu gamanam dhananāso 'rivigrahạ ||

\footnotetext{
1 dhanarddhir bhūlābhah] dhanarddhilābhạ syāt B N 4 mṛtir bhayakṛtaṃ] matir mayaṃkatam B N 5 ghoraḥ] roga B N || striyāś] striyoś K T $\quad 7$ dāraiś] pautraś B N 8 śramo] ścamo N 9 bhāskare] bhāskaro N \| phalam] śaneḥ G K T M 10 strīhataṃ] strīsahitaṃ B N G || kalir] kakșir B N || sudhākare] sudhākakare N 11 -erșyatā] -eryyatā K M 12 satkāro] saṃskāro B N; satkāraś K T M \| vijayo] ca jayo K T M 13 pura] sama B N 15 nāśo] nāśam G K T M 16 ghoraḥ] coraḥ B N 18 bandhūnām] vadhṛtām K \| rujạ̣] rajaḥ B N 19 'rivigrahah] ravigrahah B N K T M
} 
blood; in [that of] Mercury, increase of wealth, gain of land, and gain of happiness, riches and desired [objects]; ${ }^{97}$ in [that of] Jupiter, happiness from wealth, enjoyment of a province, good conduct and piety; in [that of] Saturn, making love to old women, and authority over friend and foe; [in that of Rāhu], death, grief caused by fear, and arrival of suffering, without doubt; [in that of Ketu], burns from fire, terrible fever, the birth of a daughter and loss of wife.

This concludes the mudda of Venus.

\subsubsection{The Period of Saturn and Its Subperiods}

In [the period] of Saturn, there will be pain in the body, discord with wife and children, lethargy, fatigue, loss of reason, and travel abroad. In [the subperiod of] the sun in the period [of Saturn], the result is loss of children, wealth, friends and wife; in [that of] the moon, the killing of [the native's] wife, separation from kinsmen, quarrels, and death; in [that of] Mars, suffering, illnesses, leaving the country, and envy of many kinds; in [that of] Mercury, happiness, good fortune, honours, victory and wealth; in [that of] Jupiter, happiness [from causes] befitting [one's station] and rulership of a town, village or assembly; in [that of] Venus, friendship with numerous women, renown and riches; [in that of Rāhu], agitation of kinsmen, great suffering, loss of wealth and grave danger; [in that of Ketu], burns from fire, terrible fever, the birth of a daughter and unhappiness ${ }^{98}$ from women.

This concludes the mudda of Saturn.

\subsubsection{The Period of Rāhu and Its Subperiods}

In [the period of] Rāhu there is suffering for kinsmen and illnesses for [the native] himself, travel to other countries, loss of wealth, and

97 Or 'loved ones'.

98 Or, less likely, 'happiness'. 
rāhor daśāyāṃ bhāryāyā vipattir bāndhavakșayah |

arthanāso 'nyadeśeșu gamanam gauravālpatā $\|$

aśubhaṃ vānyajạ̣ dainyaṃ vyādhibhītịn sutakșayam |

kurute siṃhikāsūnor bhānur antar daśāṃ gatạ \|

vahniśokabhayam ghoram bandhüdvegam dhanakșayam |

karoti simnikāsūnor vidhur antar daśām gatạ̣ ||

kāmārthanāśam udvegaṃ bandhuvairādikam bhayam |

karoti siṃhikāsūnor bhūmijo 'ntar daśām gatah \|

bandhunāśam manastāpaṃ deśatyāgaṃ dhanakṣayam |

karoti bahuduḥkhāni rāhor antargato budhah \|

bandhudveșam mrșāōādam samyag bandhunirāśrayam |

karoti siṃhikāsūnor gurur antar daśāṃ gatah \|

bandhūdvegam mahāduḥkham arthanāśam mahad bhayam |

śarīre kleśam āpnoti rāhor antargate site \|

mrtim bhayakrtam śokaṃ duhkhaprāptim asaṃśayam |

karoti siṃhikāsūnoḥ śanir antar daśām gataḥ \|

iti rāhumuddam ||

ketor daśāyām syād vādo dravyaputrakșayo 'sukham |

śatrurājakulād bhītir anartho bahudhā bhavet ||

agnidāho jvaro ghoraḥ kanyājanma striyāś cyutį̣ |

ketor antargate sūrye rājña saha kalir bhavet \|

arthanāśo 'rthalābhaś ca sukhaduḥkham ca jāyate |

strìlābhaś ca striyo hānih ketor antargate vidhau \|

prajayā saha samvvādaś cauravahnyādijaṃ bhayam |

1 daśāyāṃ bhāryāyā] daśādhāyā B N || bāndhava] vadhava B a.c. N $\quad 2-3$ artha ... kṣayam] om. B N 3 vyādhi] vyādhim K T M 4 kurute] kurujo B N; karoti K T M $\quad 7$ vairādikaṃ] scripsi; cauradikaṃ B; caurādikaṃ N G K T; corādikaṃ M 10 antargato] antardaśām K T M 11 nirāśrayam] nirāśramaḥ B; nirāśrayaḥ N G 13 bandhūdvegaṃ] vaṃdhudveșaṃ K T; baṃdhudveșam M $\|$ nāśaṃ] scripsi; nāśo B N G K T M 14 antargate] aṃtargatah B N G || site] sitaḥ B N G 15 bhayakṛtaṃ] bhayaṃ kṛśaṃ B N; bhayakṛtiṃ K T M || prāptim asaṃ́ayam] prāptir na saṃśayah K T; prāptiṃ na saṃśayạ̣ M $\quad 16$ sūnoh] sūnau G $\quad 18$ kṣayo 'sukham] kṣayau sukham M 20 agnidāho] anidāho N || jvaro] jaro B N; jvaroro T \| janma] janyā B N 21 sūrye] sūryo G $21-23$ sūrye ... antargate] om. B N 23 striyo] striyā M 24 saha] prajāyā B N || saṃvādaś] sahaḥ B N \|| vahnyādijaṃ] vanhyārijaṃ G; vanhyarijaṃ $\mathrm{K}$; ; vahnyarijam $\mathrm{M}$ 
conflict with enemies. In the period of Rāhu there is misfortune for [the native's] wife and loss of kinsmen, loss of wealth, travel to other countries, and little respect. ${ }^{99}$ [The subperiod of] the sun entering the period of Rāhu makes harm from forests, wretchedness, dangers from illness and loss of children. [The subperiod of] the moon entering the period of Rāhu makes terrible danger from fire and grief, agitation of kinsmen and loss of wealth. [The subperiod of] Mars entering the period of Rāhu makes loss of love ${ }^{100}$ and wealth, agitation, and danger from enmity with kinsmen and so on. [The subperiod of] Mercury entering [the period of] Rāhu makes loss of kinsmen, mental suffering, leaving one's country, loss of wealth, and many sorrows. [The subperiod of] Jupiter entering the period of Rāhu makes enmity among kinsmen, lying, and complete loss of support from kinsmen. When [the subperiod of] Venus enters [the period of] Rāhu, one meets with agitation among kinsmen, great unhappiness, loss of wealth, grave danger, and bodily suffering. [The subperiod of] Saturn entering the period of Rāhu makes death, grief caused by fear, and arrival of suffering, without doubt.

This concludes the mudda of Rāhu.

\subsubsection{The Period of Ketu and Its Subperiods}

In the period of Ketu there will be arguments, loss of goods and children, and unhappiness; there will be danger from enemies and princely families, and reversals of many kinds. When [the subperiod of] the sun enters [the period of] Ketu, there will be burns from fire, terrible fever, the birth of a daughter and loss of a wife, and quarrel with the king. When [the subperiod of] the moon enters [the period of] Ketu, there is loss of wealth and gain of wealth, happiness and distress, gaining a wife and losing a wife. When [the subperiod of] Mars enters [the period of] Ketu, there are lawsuits with one's offspring, danger from robbers, fire

99 Here Rāhu is mentioned twice, while no results are given for the subperiod of Ketu.

100 Or 'of desire', or 'of [objects of] desire'. 
svanāśo dehapị̄̂a ca ketor antargate kuje \| caurair vā śatrubhir yuddham dehatyāgo 'bhijāyate |

dehapịdājvaras tīvrah ketor antargate budhe \| dvijendraih saha samprïtir nrpapüjyair amarșibhị̣| kulastrīṣu sutotpattih ketor antargate gurau \|

ketor antargate śukre vipraị saha kalir bhavet |

vātapittakrtā pị̂ā gotrajaị saha vigrahaḥ $\|$ videśagamanam duḥkham ketor antargate 'rkaje | suhrdbandhusutair dvandvo bhünimittạ̣ kalir bhavet | iștaiś ca raṇasamvādau rāhau ketvantarasthite ||

iti ketumuddam $\|$

iti muddadaśāvicāre sarvagrahāṇāṃ muddāntardaśā samāptā | atra svadaśāphalam eva svāntardaśāphalaṃ jñeyam | atha yatra grahanāma noktaṃ tatrārdhaślokena pūrvoktagrahād agrimagrahaphalaṃ jñeyam iti viśeșah | samāpteyaṃ gaurīmatadaśā muddābhidhā | mahādevamatadaśāphalam etad eva jñeyam ||

atha rāmamatadaśā tājikamuktāvalyām uktā |

balarāmamatād raudrāc catustribhir iha kramāt |

daśeśā nakhapañcāśadbhāni śaileșavah surāḥ|

1 svanāśo] svanāmo B N || ketor antargate] kecataur N 3 tīvrah] tīvro B N G 4 amarșibhih] amarttibhị̣ B; amartibhiḥ N; amarmabhị̣ G 6-8 ketor ...'rkaje] om. B N 8 'rkaje] śanau K T M 9 dvandvo bhū] bhūmimittam N $\quad 10$ antarasthite] antarangate K T M 12 iti ... samāptā] om. B N G || samāptā] samāptam K 13 atha] athavā G $\quad 13-14$ atha ... jñeyam] om. B N 13 grahanāma noktaṃ] grahāṇām anuktaṃ K T M 15 samāpteyaṃ] samāptoyaṃ KT || gaurīmatadaśā] gaurīmaṃtardaśā K; gaurīmaṃtarddaśāT 16 etad eva] idaṃ B N 17 uktā] om. K T M 18 balarāma] balamāna B N

18 balarāma ... kramāt] TM $86 \quad$ 19-86o.2 daśeśā ... sammatā] TM 87 
and so on, self-destruction and bodily suffering. When [the subperiod of] Mercury enters [the period of] Ketu, fighting with robbers or enemies comes to pass, leaving the body [or] bodily suffering, and a violent fever. When [the subperiod of] Jupiter enters [the period of] Ketu, there is affection between [the native and] eminent Brahmans who are honoured by the king [but] irascible, and birth of children though women of good family. When [the subperiod of] Venus enters [the period of] Ketu, there will be quarrels with Brahmans, suffering caused by [the humours of] wind and bile, and discord with clan members. ${ }^{101}$ When [the subperiod of] Saturn enters [the period of] Ketu, there is travel aboad and suffering. When [the subperiod of] Rāhu enters [the period of] Ketu, there will be strife with friends, kinsmen and children, quarrel on account of land, and combat and lawsuits with loved ones.

This concludes the mudda of Ketu.

In the consideration of mudda periods, this concludes the subperiods in the muddas of all the planets. The results of each [planet's major] period is here to be understood as the result of its own subperiod [within that period]. Also, as a special consideration, when the name of a planet is not given, the result should be understood to belong to the planet following the one named in the preceding half-stanza. This concludes the periods according to the school of Gaurī, called mudda. The results of the periods according to the school of Mahādeva should be understood to be the same.

\subsection{Periods according to the School of Balarāma}

Next, the periods according to the school of [Bala]rāma are described in Tājikamuktāvali [86, 87, and Tājikamuktāvalițippaṇi 3.7-10]:

According to the school of Balarāma, the rulers of the periods are [counted alternately] by fours and threes in order from [the asterism] of Rudra. ${ }^{102}$

Their days are considered to be twenty, fifty, twenty-seven, fiftyseven, thirty-three, sixty-three, forty and seventy, [respectively]. These

\footnotetext{
101 That is, relatives sharing a paternal line (gotra).

102 That is, from Ārdrā. This counting presupposes a formal arrangement of 28 asterisms, including Abhijit.
} 
tryañgāni khābdayaḥ pūrnaśailās taddivasā matāḥ|

varșapraveśanakșatrād daśeyam rāmasammatā $\|$

baloktito yasya daśāgrahasya yādyā daśā syād bhavaśād dinādyā \|

catustrinakșatrapater bhajet tām svabhapramityaikakabhasya bhuktiḥ|

yā vartamānasya tu bhasya bhuktih sā tadbhabhuktaisyaghațīinighnā $\|$

bhājyātha tadbhasya gataisyanādīyogena labdhe gatagamyake staḥ| yute vidheye gatagamyabhānām bhuktyā dinādye gatagamyake stah \| prākpākanāthadyucarasya tasya gamyapramāṇādidaśā dinādyā| parāḥ pareșạ̣̄ dyusadāṃ yathā syāt prānte punar yātamitādimasya || iti |

udāharaṇam | varṣapraveśe puṣyanakṣatraṃ tenādau sūryadaśā jātā dinādyā 10 20 | atheyam daśā caturnakṣatreśā | ato daśādināni caturbhaktāni labdhā 5 ekaikanakṣatrasya dinādyā bhuktih | atha puṣyanakṣatrasya bhuktaghațībhir 12 bhasya bhuktir 5 gunitā 6o sarvarkșaghațī- 6o bhaktā labdhā puṣyasya gatā bhuktir dinātmikā 1 | iyaṃ gatanakṣatrayor ārdrāpunarvasvor bhuktyā 10 yutā 11 jātā raver daśā gatā | atha puṣyabhogyaghațîbhị 48 bhabhuktir 5 guṇitā 240 sarvarkṣaghațī- 6o bhaktā labdhā 4 puṣyasya gamyā bhuktiḥ | iyam gamyabhasyāśleșābhidhasya bhuktyā 5 yutā 9 jātā raver gamyā daśā | tatrādau raver gamyadaśā dinātmikā 9 | tataś candrasya 5o bhaumasya $26 \mid 40$ budhasya $56 \mid 40$ śaneh $33 \mid 20$ guroḥ $63 \mid 20$ rāhoh 40 śukrasya 70 | punah prānte gatadinamitā 11 raver daśā jñeyeti ||

\begin{abstract}
1 tryangāni] angāni $\mathrm{G}$ \| khābdayah] vābdhayah K M 3 baloktito] balodito K T; baloditā M 4 -aikakabhasya] -aikakamasya K; -aikakramasya T M 5 vartamānasya] vartamānosya $K$ T || bhasya] bhusya K || bhuktiḥ] muktiḥ K || bhuktaișya] bhaktaișya K T M || ghațī] țī N 6 labdhe] labdho K T M $\|$ stah]] te G K T M 7 yute] prāk te B N \| vidheye] vidheyo N \| bhuktyā dinādye] bhuktyādyanāḍye B N 8 tasya] om. B 9 yathā syāt] yathā syād B N; yathāsthād G || prānte] yāte B N G || yāta] jāta K T M || mitādimasya || iti] mitā dinasyeti B N G 11 bhaktāni] bhuktāni K T M 13 bhasya] bhaktasya B N G \| bhuktir] bhukti B N || 5] om. G || sarvarkșa] sarva B N 14 iyaṃ] evaṃ B N || bhuktyā] bhaktyā G 15 10] 20 B || daśā gatā] gatadaśā K T M || bhogya] om. K T M || bhabhuktir] bhabhukti B; bhabhuktinātmikā 1 evaṃ gatanakṣatrayor ārdrāpunarvasvor bhuktyā 10 yutā 11 jātā raver ddaśā gatā || atha puṣyabhogyaghațīmiḥ 48 N $\quad 16$ 240] 24 B $\quad 17$ bhuktyā] bhuktā BN || 9] om. G 18 gamya] gatagamya B N G
\end{abstract}

3-9 baloktito ... ādimasya] TMṬ 3.7-10

1 tryangāni] The reading of $\mathrm{G}$ is another instance of confusion of the characters $a$ and trya in northern-style Devanāgarī. 
periods are regarded by [Bala]rāma [as commencing] from the asterism [occupied by the moon] at the revolution of the year.

According to the statement of Bala[rāma], whichever period in days and so on comes first on account of the asterism, belonging to any period planet ruling four or three asterisms, one should divide that [period] by its extension in asterisms: [the result is] the duration of each asterism. Then, the duration of the current asterism, multiplied [separately] by the elapsed and remaining ghațis of that asterism, should be divided by the sum of the elapsed and remaining nădīs of that asterism: the result is the elapsed and remaining [parts of the period of that asterism, respectively]. They are to be added to the duration of the elapsed [or] remaining asterisms: [the result] is the elapsed and remaining [parts of the entire period, respectively]. The first period comprises the remaining [part], in days and so on, of that planet ruling the first period; then [follow the periods] of the other planets in order; and last [comes the period] comprising the elapsed part of the first [planet].

An example: in the revolution of the year, the asterism [occupied by the moon] was Pusya; therefore the period was that of the sun, [comprising] 20 days and so on. ${ }^{103}$ Now, this period is governed by four asterisms; therefore, the days of the period are divided by four, giving each asterism a duration of 5 days and so on. Now, the duration of an asterism (5), multiplied by the 12 elapsed ghațis of the asterism Puṣya (6o) and divided by all the ghațis in an asterism (6o) gives an elapsed duration of 1 day for Pusya. This, added to the duration of the elapsed asterisms Ārdrā and Punarvasu (10), gives 11 [days] as the elapsed [part of the] period of the sun. Next, the duration of an asterism (5), multiplied by the 48 remaining ghațiss of the asterism Pușa (240) and divided by all the ghațis in an asterism (6o) gives a remaining duration of 4 days for Pusya. This, added to the duration of the remaining asterism called Áśleșā (5), gives 9 [days] as the remaining [part of the] period of the sun. In that [figure], the remaining [part of the] period of the sun [comes] first, comprising 9 days; then [the period] of the moon, 50; of Mars, 26;40; of Mercury, 56;40; of Saturn, 33;20; of Jupiter, 63;20; of Rāhu, 40; of Venus, 70; and last, the period of the sun should be understood [to recur], comprising the 11 days of the elapsed [ ghațis].

103 The phrase 'and so on' as used in this paragraph seems gratuitous, as the periods mentioned only comprise whole days, not fractions in ghațis and palas. 


\begin{tabular}{|c|c|c|c|c|}
\hline $\begin{array}{l}\text { rāmamata- } \\
\text { daśeśāḥ̣ }\end{array}$ & $\begin{array}{l}\text { varșa- } \\
\text { praveśabhāni }\end{array}$ & $\begin{array}{l}\text { varșe } \\
\text { daśādināni }\end{array}$ & $\begin{array}{l}\text { māsa- } \\
\text { daśādināni }\end{array}$ & $\begin{array}{l}\text { dina- } \\
\text { daśāghațyaḥ }\end{array}$ \\
\hline sūryah & ārdrā 4 & $20 \mid \mathrm{O}$ & $1|40| 0$ & $3|20| 0$ \\
\hline candrah & maghā 3 & 5 잉 & $4|10| 0$ & $8|20| 0$ \\
\hline mañgalah & hastā 4 & $26 \mid 40$ & $2|13| 20$ & $4|26| 40$ \\
\hline budhah & anurādhā 3 & $56 \mid 40$ & $4|43| 20$ & $9|26| 40$ \\
\hline śanih & pūrvāṣāộhā 4 & $33 \mid 20$ & $2|46| 40$ & $5|33| 20$ \\
\hline bṛhaspatih & dhanișṭhā 3 & $63 \mid 20$ & $5|16| 40$ & $10|33| 20$ \\
\hline rāhuḥ & u.bhadrapadā 4 & $40 \mid 0$ & $3|20| \mathrm{o}$ & $6|40| 0$ \\
\hline śukrah & krrttikā 3 & $70 \mid 0$ & $5 \mid 5$ o|o & $11|40| 0$ \\
\hline yogah & 28 & $36 \circ$ & 30 & 60 \\
\hline
\end{tabular}

atra prakārāntaraṃ varṣaphalapradīpe |

varșapraveśe dinabhetanā phalam dinādyam hi daśā gatā syāt tadūnitādyasya daśā tadeșyā || varșapraveśe prathamam daśā sā tatah kramenaivam ihetareșām| varșasya cānte prathamasya yātā daśā bhaved abdaphalasya siddhyai $\|$ varșapraveśe dinabham ca yat syāt tasyādhipatyādyadaśā bhavet sā| tatas tu tatkhețadaśākrameṇa daśā bhaveyuh sadasatphalārtham \|

\footnotetext{
1 rāmamata-] yogarāmamata B $\quad 2$ daśādināni²] daśādite K T M || ghațyaḥ] ghāḥ G 3 $3|20| 0] 32020$ B 5 26|40] 36 40 G; 27 ० K T M \|| 4|26|40] 46 o K T M 6 56|40] 57 40 K T M || 9|26|40] 926 оо K T M $733 \mid 20] 3322 \mathrm{G} \mathrm{||} \mathrm{2|46|40]} 2$ 40 40 K T M || 5|33|20] 523 $20 \mathrm{G} \quad 8$ 10|33|20] $13320 \mathrm{G} 9$ rāhuh] śa G \| 3|20|o] 326 40 B; 330 o० G; 2 30 o K T M ॥ 6|40|o] 7 oo oo G 10 krttikā] ha G || 3] 4 T || 5|50|o] 50 50 o T \| 11|40|o] 1740 o KTM 11 28] 20 K T M 12 prakārāntaraṃ] prakārāṃta G 13 dinabheta] dinabhe na M || khaṣaḍ] khaț G 14 gatā syāt] gatasya K M \| tadūnitā-] tadūjjhitā- $\mathrm{G} \quad 15$ prathamaṃ] mathamạ̣ N || sā] sati B N 17 -ādhipatyā-] -ādhiyasyā- K; -ādhipasyā- T M 18 sadasat] sadat B

1 rāmamata-] The following table is omitted by N. Other text witnesses give the names of the planets and asterisms in abbreviated form. $\mathrm{K} \mathrm{T}$ M divide the table in two, omitting the first three column headings.
} 


\begin{tabular}{lllll}
\hline $\begin{array}{l}\text { Period rulers } \\
\text { according to the } \\
\text { school of Rāma }\end{array}$ & $\begin{array}{l}\text { Asterisms in the } \\
\text { revolution }\end{array}$ & $\begin{array}{l}\text { Days in } \\
\text { a year }\end{array}$ & $\begin{array}{l}\text { Days in } \\
\text { a month }\end{array}$ & $\begin{array}{l}\text { Ghațis } \\
\text { in a day }\end{array}$ \\
\hline Sun & 4 from Ārdrā & $20 ; 0$ & $1 ; 40,0$ & $3 ; 20,0$ \\
Moon & 3 from Maghā & $50 ; 0$ & $4 ; 10,0$ & $8 ; 20,0$ \\
Mars & 4 from Hastā & $26 ; 40$ & $2 ; 13,20$ & $4 ; 26,40$ \\
Mercury & 3 from Anurādhā & $56 ; 40$ & $4 ; 43,20$ & $9 ; 26,40$ \\
Saturn & 4 from Pūrvāṣāḍhā & $33 ; 20$ & $2 ; 46,40$ & $5 ; 33,20$ \\
Jupiter & 3 from Dhanișțā & $63 ; 20$ & $5 ; 16,40$ & $10 ; 33,20$ \\
Rāhu & 4 from U.Bhadrapadā & $40 ; 0$ & $3 ; 20,0$ & $6 ; 40,0$ \\
Venus & 3 from Kṛttikā & $70 ; 0$ & $5 ; 5 \circ, 0$ & $11 ; 40,0$ \\
Total & 28 & 360 & 30 & 60 \\
\hline
\end{tabular}

Here is another method, [described] in the Varșaphalapradipa:

The period of the first [planet] is multiplied by the elapsed nādīs of the asterism [occupied by the moon] on the day of the revolution of the year and divided by sixty: the result in days and so on will be the elapsed [part of the] period; the [entire] period of the first [planet] less by that [elapsed part] is its remaining [part]. In the revolution of the year, that period [comes] first, then similarly [those] of the other [planets] in order; and at the end of the year, the elapsed [part of the] period of the first [planet] will complete the results of [that] year. Whichever is the asterism [occupied by the moon] on the day of the revolution of the year, the first period will come under its rulership; the periods of the planets will follow in order from that for the sake of [bestowing] good and evil results. 
atha janmakālābhāve janmarāśivaśād daśānayanam uktaṃ tatraiva |

janmakālādyabhāvaś cet kecij janmabhato viduḥ|

tad eva procyate pumsāṃ śubham tad vārșikam phalam \|

janmany arkadaśā tato vidhudaśā yāvad dvitīyo ravis

tristhe 'rke daśavāsarā śaśidaśā bhaumasya pākas tataḥ |

bandhusthe 'dridinam tato budhadaśa ȳavvat sutastho ravih

șașthe cābdhidinam tatah śanidaśā syāt saptame digdinam \|

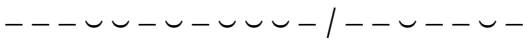

nandasthe 'ștadinam ravau gurudaśa diksthe tamo viṃśatị̣|

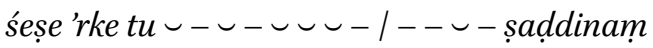

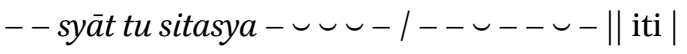

atrāntardaśānayanaṃ phalasahitam uktaṃ tatraiva |

6 bandhusthe] șaṃdhusthe $\mathrm{N} \|$ budha] dudha N 7 syāt saptame digdinam] saptasthite sapta ca G K T M || saptame] satame N $\quad 9-11$ nandasthe ... iti] om. G K T M 9 diksthe] dikathe $\mathrm{N}$

9-11 nandasthe ... iti] For the stanza in śärdūlavikrị̄ita metre apparently partially preserved by B N, the following in upajāti is given by G K T M: tato daśejyasya (jyasya K) ca yāvad așta nava (nave $\mathrm{G}$ ) sthite 'rke daśa vāsarāḥ (vāsarā $\mathrm{T}$ ) syuḥ (syu $\mathrm{G}$ ) tatas tu rāhor ddaśame ca sūrye vimiśad dinaṃ (dina $\mathrm{K} \mathrm{T}$ ) syāt tu tatạ (tatas $\mathrm{K})$ sitasyeti.

104 While the moon is not explicitly mentioned, this is the most common meaning of the compound janmabha or janmarâsí. A less likely but not impossible meaning would be the sign occupied by the sun itself, giving every person the same sequence of periods in a year.

105 Counting in solar 'days' or degrees of ecliptical longitude covered by the sun in a year, and depending on the position of the sun within its zodiacal sign on the birthday (which could make the first period vary between o and 30 days), the first five periods of 


\subsubsection{Periods When the Time of Birth Is Unknown}

Next, a calculation of periods on the basis of the sign [occupied by the moon] in the nativity when the time of birth is unavailable is described in the same [Varșaphalapradipa]:

If the time of birth is unavailable, some acknowledge [periods reckoned] from the zodiacal sign [occupied by the moon] in the nativity: ${ }^{104}$ from that alone, the beneficial results of the year are declared for men.

[While the sun transits the sign occupied by the moon] in the nativity, it is the period of the sun; then, while the sun is [in] the second [sign], the period of the moon; with the sun in the third [sign], the period of the moon [continues] for ten days; then the period of Mars [lasts for the rest of that sign]; when [the sun] occupies the fourth [sign, the period of Mars continues] for seven days; then the period of Mercury [lasts throughout that sign and] while the sun is in the fifth [sign], and for four days [while it is] in the sixth; then it will be the period of Saturn [while the sun remains in the sixth and] for ten days [while it is] in the seventh; ${ }^{105}[\ldots]$ for eight days when the sun occupies the ninth, the period of Jupiter; when it occupies the tenth, twenty [days for that of] Rāhu; and when the sun is in the remaining [...] six days [...] will be that of Venus $[. ..] .^{106}$

\subsubsection{The Period of the Sun and Its Subperiods}

Concerning this, ${ }^{107}$ the calculation of subperiods along with their results is described in the same [Varșaphalapradipa]:

this system thus comprise 160-19o days, or approximately half a year. The remaining periods would belong to Jupiter, Rāhu, Venus, and presumably the sun to end the cycle with the days remaining between its ingress into its natal zodiacal sign and the next birthday. The order of periods is identical to that just outlined above (according to the school of Balarāma), which does not include Ketu.

106 The fragmentary stanza beginning with the first ellipsis is replaced in text witnesses G K T M by one in a different metre: 'Then the period of Jupiter [lasts] while [the sun is in the] eight[h sign]; when the sun occupies the nin[th], ten days will be [those of Jupiter]; then [the period] of Rāhu [lasts for the rest of that sign and] for twenty days when the sun is in the tenth; then [the period] of Venus.' The duration of the period of Venus is not stated; possibly it is meant to last for the remainder of the year, or at least until the sun's ingress into its natal zodiacal sign (some 70 days). The contents of this stanza do not seem exactly to match the fragmentary one preserved in the two earliest text witnesses.

107 That is, the periods according to the school of Balarāma, not merely for nativities with unknown birth times. 
daśāh svapākair nihatāḥ khașațkarāmair hrtā labdhaphalam dinādyam | antardaśāh syuḥ svadaśākrameṇa phalāni tāāạm kathayāmi cātaḥ \| nrpater bhayam atyugraṃ pị̂ā syād raktapittatah | karoti dhananāśam ca svadaśāntargato ravih \|

idam eva daśāphalaṃ jñeyam |

alpāyāsena lābhah syāt saṃgrāmādau jayas tadā | ārogyam strīsukham caiva raver antargate vidhau \| ārogyaṃ strībhavam saukhyam jayo raktāmbarāgamaḥ| anudyogena lābhah syād bhaume sūryadaśām gate \| dhanahānir virodhah syāt pīdā sopadravādibhị̂ | dhanaryayo hi süryasya daśāntaḩsthe hi bodhane \| mālapìdā nrpād bhìtir udarāmayapịditam | krșnavastūdbhavā hānị̣ sūryasyāntargate śanau \| sukhena kāryasiddhị̣ syād dhanalābho mahān bhavet | acintyo rājasanmāno gurau sūryadaśām gate || kalaho mitraputrādyaị kāryahānir nrpād bhayam | sevakebhyo vyayaś caiva rāhau sūryadaśām gate \| mohena nirbalatvam ca strivirodham dhanakșayam | kimcil lābham karoty arkadaśāyām bhārgavo gatah \|

ity arkadaśāyām antardaśāphalam ||

\footnotetext{
1 nihatāh ] nihitā K T M || hṛtā] hatā G 2 cātaḥ] cātra 1 atha phalam K T M 3 pittataḥ] pittajā K T M 4 gato] ga B 6 alpāyāsena] alpāvāsena K T \| jayas] jas B \| tadā] tathā K T M 8 raktāmbarā-] raktyambara K 9 anudyogena] anudvegena B N K T M \| bhaume] bhīme N 11 sūryasya] sūryasthe B N 12 māla] mātṛ G K T M \| bhītir udarāmaya] bhītitadārāmaya G || pị̣̄itam] pị̣̄anaṃ G K T M 14 siddhiḥ] siddhạ̣ G || mahān] mahā K T 15 rāja] rājya K T M || daśāṃ gate] daśāntare K T M 18 kṣayam] vyayaṃ G K T M 19 kiṃcil] kvacil G; kvacit K T M $\|$ lābhaṃ] kṣobha K T M
} 
The periods multiplied by [all the planets'] respective periods and divided by three hundred and sixty will result in the subperiods in the order of periods from [the period ruler] itself. I proceed to related their results:

There will be horrible danger from the king and suffering from blood and bile, and [the subperiod of] the sun entering its own period makes loss of wealth.

This should be understood as the result of the [major] period as well. [Continuing from the Varșaphalapradipa:]

There will be gain with little effort, victory in battle and so on, good health and happiness from women when [the subperiod of] the moon enters [the period of] the sun. There will be good health, happiness caused by women, victory, acquisition of red garments, and gain without exertion when [the subperiod of] Mars enters the period of the sun. There will be loss of wealth, conflict, suffering and calamities, and expense of wealth when [the subperiod of] Mercury enters the period of the sun. There is suffering concerning property, ${ }^{108}$ danger from the king, suffering from ailments of the stomach, and loss relating to black objects when [the subperiod of] Saturn enters [the period of] the sun. There will be easy success in undertakings, great gain of wealth, and inconceivable honour from the king when [the subperiod of] Jupiter enters the period of the sun. There are quarrels with friends, children and so on, failure in undertakings, danger from the king, and loss on account of servants, when [the subperiod of] Rāhu enters the period of the sun. [The subperiod of] Venus entering the period of the sun makes weakness due to confusion, conflict with women, loss of wealth [but also] some gain.

This concludes the results of the subperiods in the period of the sun.

$108 M a \bar{l} l a$, an Arabic loanword (Arabic $m a \bar{a} l)$. Text witnesses G K T M read 'mother'. 
läbhaḥ syāc chubhavastūnām kanakāyasalābhakaḥ| strïratih śleșmakopaś ca svadaśāntargato vidhuḥ \| raktapittādyakopaś ca paraiś ca kalaho bhavet | phalānāṃ vyavahārah syād bhaume candradaśām gate \| catușpadādiläbhaḥ syāt sukham dravyasya läbhakaḥ| kalahạ strīsutādyaiś ca candrāntargatabodhane \| śleșmapīdā vìryahāniḥ suūlapịdā bhayaṃ tathā| pitrmātrvirodhaḥ syāc chanau candradaśām gate \| vasträbharanalābhah syāl lābhah saurabhyavastutạ̣| mānyatā svajanebhyaś ca candrasyāntargate gurau \| niṣkāranam tathodvego dehe püdā tathā vyayah | sevakāśrayasamjāto vidhor antargatạ̣ tamaḥ $\|$ strīsukham śvetavastūnām lābhaṃ vai rājamānanam | śatrunāśam karoty āśu candrāntaḥstho hi bhärgavah \| śatrukșayo nrpāl lābho mānyatā saukhyam uttamam | vastrālaṃkāralābhah syād arke candradaśāṃ gate \|

iti candraphalam \|

raktapittakrtā pị̣̂a ripubhyo 'pi bhayaṃ bhavet | samnipātodbhavā pịdà svadaśāntargate kuje \| pittādhikyam virodhah syān mitraputrädibhis tathā| dhanavyayam kvacil läbho bhaumasyāntargate budhe \|

\footnotetext{
1 kanakāyasa] kanakāyāsa K T 3 paraiś] svajanaiś ca B N 4 phalānāṃ vyavahāraḥ] phalānādhyabahāraḥ N $\quad 5$ syāt sukhaṃ] syād alpa G K T M $\quad 8$ virodhaḥ] virodhaṃ B $\quad 9$ saurabhya] sauramya B N || vastutah]] vastunạ̣ K T M 11 niṣkāraṇaṃ] riḥkāraṇaṃ B N || pị̣āa pị̣ā add. N 12 saṃjāto] saṃyāto K T M 14 śatru] śatror K T M 15 mānyatā] mānatā K 17 candraphalam] caṃdrạ̣ G K T M 19 -bhavā] -bha N
} 


\subsubsection{The Period of the Moon and Its Subperiods}

[Continuing from the Varșaphalapradipa:]

There will be gain of pleasant objects, gain of gold and iron, love of women, and agitation of phlegm [when the subperiod of] the moon enters its own period. There will be agitation of blood and bile, quarrels with strangers, ${ }^{109}$ and dealing in fruit when [the subperiod of] Mars enters the period of the moon. There will be gain of quadrupeds and so on, happiness, gain of goods and quarrels with wife, children and so on when [the subperiod of] Mercury enters [the period of] the moon. There will be suffering from phlegm, loss of strength, ${ }^{110}$ suffering from pain, fear, and conflict with father and mother when [the subperiod of] Saturn enters the period of the moon. There will be gain of clothes and ornaments, gain from fragrant objects and respect from one's own people when [the subperiod of] Jupiter enters [the period of] the moon. There is agitation without cause as well as bodily suffering and loss caused by dependence on servants [when the subperiod of] Rāhu enters [the period of] the moon. [The subperiod of] Venus entering [the period of] the moon swiftly makes happiness from women, gain of white objects, honour from the king and destruction of enemies. There will be destruction of enemies, gain from the king, respect, utmost happiness and gain of clothes and ornaments when [the subperiod of] the sun enters the period of the moon.

This concludes the results of the moon.

\subsubsection{The Period of Mars and Its Subperiods}

[Continuing from the Varșaphalapradipa:]

There will be suffering caused by blood and bile, danger from enemies, and suffering arising from compounded illness when [the subperiod of] Mars enters its own period. There will be an excess of bile, discord with friends, children and so on, and loss of wealth [but] sometimes gain [as well] when [the subperiod of] Mercury enters [the period of]

109 Or 'enemies'.

110 Or 'virility'. 
virodho bāndhavaih sārdhaṃ dhananāso 'ñgapịdanam | samnnipātādikā pị̂ā śanau bhaumadaśām gate \| kāryopakramalābhau ca saṃrāmādau jayas tathā| dhanāgamah suhrtprāptir gurau bhaumadaśām gate \| agnicaurādijā pịdā manaścintā vyayas tathā| lābhahānị̣ kvacid vairaṃ bhaumasyāntargatam tamaḥ \| caurāgnibhayam atyugram vyayādhikyam anudyamam | manaścintām karoty eva bhaumasyāntargato bhrguh \| sahāyāt kāryasiddhịh syāl lābho rājño mahān bhavet | strīsukhạ̣ hi suhrtprāptị̣ sūrye bhaumadaśām gate \| janena kāryasiddhị syāt sukham putrādibhis tathā| vairināśo dhanaprāptiś candre bhaumadaśām gate \|

iti bhaumaphalam ||

strīsukham rājasanmānaḥ kāryasiddhis tathā bhavet | buddhiprapañcatā lābhah svadaśāntargate budhe \| kalaho vāyupịdā syād bhrtyaih saha dhanakșayah | apavādo manastāpah śanau budhadaśām gate \| suvarnapaț̣akülädiläbhạ karpūrasambhavah | suhṛtsamāgamaś caiva budhasyāntargate gurau \| buddhināso manastāpaḥ svalpaläbho dhanavyayah | suhṛdbhūpativairam ca rāhau budhadaśām gate \| strīpakșāt svalpaläbhah syād rājño läbho mahān bhavet | śvetavastvantaraprāptir budhasyāntargate bhrgau || saukhyạ̣ svajanabandhūnām mitraputrādisaṃgamaḥ|

\footnotetext{
1 dhana] dhadhana G 3 kāryo-] kāyo- B N G \| tathā] lābhahāniḥ kvacid vairaṃ add. B N 5 manaś] mataś B N 6 gatam] gataḥs B; gatas N $\quad 9$ sahāyāt] sāyāt B N $\quad 9-11$ syāl ... siddhiḥ] om. B N 13 bhaumaphalam] bhaumaḥ G K T M 14 kāryasiddhis] kāryāsiddhis N 15 buddhi] buddhị̣ K T M $\|$ sva] ska G $\quad 17$ tāpah] scripsi; tāpo B N G K T M 18 pațtakūlādi] șadakūlādi N 22 syād] syā B N 23 śvetavastvantara] śve*prāṃtara K
} 
Mars. There is discord with kinsmen, loss of wealth, bodily suffering, and suffering from compounded illness and so on when [the subperiod of] Saturn enters the period of Mars. There are new undertakings and gain, victory in battle and the like, acquisition of wealth and gain of friends when [the subperiod of] Jupiter enters the period of Mars. There is suffering from fire, robbers and so on, mental anxiety, expense, loss of profit, and occasional enmity [when the subperiod of] Rāhu enters [the period of] Mars. [The subperiod of] Venus entering [the period of] Mars makes horrible danger from robbers and fire, great loss, listlessness and mental anxiety. There will be success in undertakings with help [from others], great gain from the king, happiness from women, and gain of friends when [the subperiod of] the sun enters the period of Mars. There will be success in undertakings through [the help of common] people, happiness from children and so on, destruction of enemies and gain of wealth when [the subperiod of] the moon enters the period of Mars.

This concludes the results of Mars.

\subsubsection{The Period of Mercury and Its Subperiods}

[Continuing from the Varșaphalapradīpa:]

There will be happiness from women, respect from the king, success in undertakings, growth of understanding, and gains when [the subperiod of] Mercury enters its own period. There will be quarrels, suffering from [the humour of] wind, loss of wealth along with servants, ${ }^{111}$ slander and mental suffering when [the subperiod of] Saturn enters the period of Mercury. There is gain of gold, silk cloth and so on, [gain] arising from camphor, and the company of friends when [the subperiod of] Jupiter enters [the period of] Mercury. There is loss of reason, mental suffering, little gain, loss of wealth, and enmity with friends and the king when [the subperiod of] Rāhu enters the period of Mercury. There will be little gain from women [but] great gain from the king, and gain of different white objects when [the subperiod of] Venus enters [the period of] Mercury. There is happiness from one's own people and kinsmen, the company of friends, children and so on, destruc-

111 It is unclear from the phrasing whether loss of wealth and servants or loss of wealth in the company of servants is meant. 
vairināsó jayaprāptị sūrye saumyadaśāṃ gate || raktapittādipīdā syād daurbalyam svaśarīrake | strīyoge kalahaś caiva candre saumyadaśām gate \| śirovyathā ca suúlam syāt pīdā syāt tu dhanakșayaḥ| vigrahah svasutādyaiś ca bhaume budhadaśāṃ gate \|

iti budhaphalam \|

kuțumbakalaho mitrair virodho dhanasaṃhatih | nrpavairibhayam caiva svadaśāntargate śanau $\|$ ārogyatā mahālābho mahadbhiḥ saha saṃgatih | dvijadevaguror bhaktị śaner antargate gurau \| cauravairinrpād vāpi dhanasyodarapīdanam | duhkham karoti māndyam ca śaner antargatam tamaḥ \| vairibhyo vijayaś caiva bhrtyebhyo 'pi dhanāgamah | strīsaukhyam mitrasāphalyam śukre śanidaśām gate \| kuțumbakalahaś caiva dhanadhānyasya ca vyayah | ı̇șan manasi cintā ca sūrye śanidaśāṃ gate \| catușpadādilābhah syād vairināsó nrpād bhayam | strīsukham duḥkhanāśaś ca candre śanidaśām gate \| raktapittaprakopaḥ syāt kalaho bāndhavaị saha| dhanadhānyavyayaś caiva bhaume śanidaśām gate \| kalaho mitraputrādyair virodhaś caiva sarvadā | śatrubhyo bhayam atyugraṃ budhe mandadaśām gate \|

iti śaniphalam ||

1 jaya] jayah G K T || sūrye] sūryo B N 2 syād daurbalyaṃ] syāntairvalyaṃ G; syān nairvalyaṃ K T; syān nairbalyaṃ M 4 vyathā ca] vyathātha $K$ T \| śūlaṃ syāt] śūlasya $G$ \| tu dhana] tudyana K 6 budhaphalam] budhah G K T M $\quad 7$ kuțumba] kuṃdava N \| virodho] virodha B; viro N \| saṃhatih] saṃgatih B N 8 nụpavairibhayam ] nayanair vibhavam B || vairi] caura K T; cora M 9 mahā] mahāl K T; mahāl M $\|$ mahadbhiḥ] maharddhih B N || saṃgatih] saṃgamaḥ K T M 10 guror] gurau K T 12 gatam] gatas K T M \|t tamạ̣] gamaḥ B; samaḥ N 16 manasi] masi B; masiṃ N \| cintā] ciṃtaṃ B; citaṃ N \| ca] syāt K T M 17 vairi] ari K T M 18 nāśaś] nāśam B N G; nāśañ K T \| ca] om. B 20 bhaume śanidaśāṃ gate] śaner aṃtargate kuje G K T M $\quad 21-22$ kalaho ... gate] om. B N 23 śaniphalam] śaniḥ G K T M 
tion of enemies and gain of victory when [the subperiod of] the sun enters the period of Mercury. There will be suffering from blood, bile and so on, weakness in one's body, and quarrel in uniting with women when [the subperiod of] the moon enters the period of Mercury. There will be headache and pain, suffering and loss of wealth, and discord with one's children and so on when [the subperiod of] Mars enters the period of Mercury.

This concludes the results of Mercury.

\subsubsection{The Period of Saturn and Its Subperiods}

[Continuing from the Varșaphalapradippa:]

There are quarrels in the household, discord with friends, frugality with money and danger from the king and enemies when [the subperiod of] Saturn enters its own period. There is good health, great gain, the company of great men, and devotion to Brahmans, gods and teachers when [the subperiod of] Jupiter enters [the period of] Saturn. [The subperiod of] Rāhu entering [the period of] Saturn makes [suffering] from robbers, enemies or the king, [suffering from loss] of wealth and suffering from the stomach, unhappiness and weakness. There is victory over enemies and acquisition of wealth from servants, happiness from women and advantage from friends when [the subperiod of] Venus enters the period of Saturn. There are quarrels in the household, loss of wealth and grains, and a little anxiety in one's mind when [the subperiod of] the sun enters the period of Saturn. There will be gain of quadrupeds and so on, destruction of enemies [but] danger from the king, happiness from women and an end to unhappiness when [the subperiod of] the moon enters the period of Saturn. There will be agitation of blood and bile, quarrels with kinsmen and loss of wealth and grains when [the subperiod of] Mars enters the period of Saturn. There are quarrels with friends, children and so on, constant discord, and horrible danger from enemies when [the subperiod of] Mercury enters the period of Saturn.

This concludes the results of Saturn. 
kāryasiddhir nṛpād bhütir dhanadhānyādisampadaḥ|

pramehabhavapīdā syāt svadaśāntargate gurau \| dadrukaṇduprakopaś ca raktakopah pramehatah |

balahānis tv arthanāśs rāhau jīvadaśām gate \| śukrasyāpi phalam rāhuphalavad guruvad raveh |

strīsukham saṃtateh saukhyam guror antargate vidhau \|

cintitasya ca kāryasya siddhih syāt tu dhanāgamaḥ|

śarīrārogyakam caiva bhaume jīvadaśām gate \|

budhasyāpi phalam bhaumaphalavac cātha vāyubhīh |

buddhināso vyayaś caiva śanau jīvadaśām gate \|

iti guruphalam ||

paradeśagamas tatra caurebhyo 'pi mahad bhayam |

mānahāniḥ śastrapị̣ā rāhau nijadaśām gate \|

arthalābhạ̣ kāryasiddhih śukre rāhudaśāṃ gate |

jvarātisārarogaś ca rāhor antargate ravau \|

candrasya rāhuvac cārdharavivad bhaumajam phalam |

budhasya śukravac cārdharāhuvac ca śaneh smrtam ||

samau lābhavyayau caiva mitraśatrusamāgamaḥ|

miśram caiva phalaṃ vācyam gurau rāhudaśāṃ gate \|

iti rāhuphalam ||

1 ṇ̣pād bhītir] nụpād bhītiṃ B N; nụpān māna G K T M $\quad 2$ bhava] dhana B N G 4 rāhau jīva] rāhāv ỉjya G T; rāhov ỉjya K; rāhāv ijya M \| gate] gatau B N 8 śarīārogyakaṃ] śarīrorogyake B N || gate] gateh saukhyaṃ guror aṃtarga B; gateh khyaṃ guror aṃtarga N $\quad 11$ guruphalam] guruh G K T M 12 para] ya $-\mathrm{G} \|$ deśa] deśe $M \|$ gamas tatra] gamaś caiva K T M 13 māna] mahā G 16 cārdha] cārddhaṃ G 17 cārdha] cārddhạ̣ G K T M 18 lābha] lābhau B N G 19 miśraṃ] mitram B N G \|v vācyaṃ] lābhaṃ B N; cāte G 20 rāhuphalam] rāhuḥ G K T 


\subsubsection{The Period of Jupiter and Its Subperiods}

[Continuing from the Varșaphalapradipa:]

There will be success in undertakings, danger from the king, abundance of wealth, grains and so on [but] suffering caused by urinary disease when [the subperiod of] Jupiter enters its own period. There is skin disease and irritation from itching, agitation of blood due to urinary disease, failing strength and loss of wealth when [the subperiod of] Rāhu enters the period of Jupiter. The results of Venus are like the results of Rāhu, and [those] of the sun are like [those of] Jupiter. There is happiness from women and happiness from offspring when [the subperiod of] the moon enters [the period of] Jupiter. There will be success in a planned undertaking, acquisition of wealth and good health of the body when [the subperiod of] Mars enters the period of Jupiter. The results of Mercury are like the results of Mars, and also danger from [the humour of] wind. There is loss of reason and expense when [the subperiod of] Saturn enters the period of Jupiter.

This concludes the results of Jupiter.

\subsubsection{The Period of Rāhu and Its Subperiods}

[Continuing from the Varșaphalapradippa:]

There is travel to foreign countries and grave danger from robbers during that [travel], loss of honour and suffering from weapons when [the subperiod of] Rāhu enters its own period. There is gain of wealth and success in undertakings when [the subperiod of] Venus enters the period of Rāhu, and diarrhoea with fever when [the subperiod of] the sun enters [the period of] Rāhu. The results of the moon are like [those of] Rāhu, and those of Mars like half of [those of] the sun; [those] of Mercury are like [those of] Venus, and [those] of Saturn are said to be like half of [those of] Rāhu. Gain and loss in equal measure, encounters with friends and enemies, and mixed results [in everything] should be predicted when [the subperiod of] Jupiter enters the period of Rāhu.

This concludes the results of Rāhu. 
strīsaukhyam nrpamānaḥ syād raupyāśvādisamāgamaḥ| śvetavastos tathārogyam svadaśāntargate bhrgau \| yatnena kāryasiddhiḥ syād rājasanmānam eva ca| mahatī prītir ārogyaṃ ravau śukradaśām gate \| strīsukhaṃ śvetavastūnāṃ lābhạ̣ vai rājamānatām | karoti śatrunāśam ca candre śukradaśāṃ gate \|

kvacid duḥkhaṃ kvacit saukhyaṃ kvacil läbham kvacid yaśạ̣| prāpnoti puruṣo nityaṃ candre śukradaśāṃ gate || iti vā pāțhạ̣ |

saṃtāpaḥ kalahaś caiva pittakopasamāgamaḥ| śatrūṇām raktakopaś ca bhaume śukradaśām gate \| kaṇdüraktātipittaṃ ca vihāro hemasambhavaḥ| dhanadhānyaryayaś caiva śukrasyāntargate budhe \| akasmāc ca dhanaprāptih parebhyo hinavastutah | lābhah syād bhārgavasyāntar daśā yadi śanes tadā || rājyaprāptir dravyalābhas tv alpāyāsena karma ca| saphalam ca bhavec chukradaśāmadhye guror yadā $\|$ svajanaiś ca virodhah syād vāyuś codarasambhavaḥ| śūlarogo vyayaś caiva rāhau śukradaśām gate \|

iti śukraphalam | iti rāmamatadaśāyām antardaśāḥ samāptāḥ ||

\footnotetext{
1 mānaḥ] mānyaḥ B N || raupyā-] rauṇā- K $\quad 2$ vastos] vastāṃs K $\quad 5$ sukhaṃ] sukhe $\mathrm{K}$ \| vai rāja] vairāgya B N G 7 kvacit] kvacci N \| lābhaṃ] lābhạ̣ G K T 8 iti vā pāțhaḥ] om. B N G 9 kopa] kopaḥ K T M 11 raktāti] raktādi K T \| vihāro] vihāre B N G || hema] he B 13 vastutaḥ] vastunaḥ K M 14 lābhạ̣] lābhạ̣ B N G 15 lābhas tv alpā-] lābhah svalpā- K T M 17 virodhah] vinodah B N $\|$ vāyuś] vyayaś K T M $\quad 18$ rogo] roge G 19 śukraphalam] śukraḥ G K T M
} 


\subsubsection{The Period of Venus and Its Subperiods}

[Continuing from the Varșaphalapradipa:]

There will be happiness from women, honour from the king, acquisition of silver, horses and so on, and also of white objects, and good health when [the subperiod of] Venus enters its own period. There will be success in undertakings with effort, honour from the king, great affection and good health when [the subperiod of] the sun enters the period of Venus. When [the subperiod of] the moon enters the period of Venus, it makes happiness from women, gain of white objects, honour from the king and destruction of enemies.

[For the last verse], there is another reading: 'Whenever [the subperiod of] the moon enters the period of Venus, a man sometimes meets with unhappiness, sometimes happiness, sometimes gain, sometimes renown.' [Continuing from the Varșaphalapradippa:]

There is affliction and quarrels, the onset of agitation of bile, [fury] of enemies and agitation of blood when [the subperiod of] Mars enters the period of Venus. There is itching, excess of bile [affecting] the blood, enjoyment arising from gold, and loss of wealth and grains when [the subperiod of] Mercury enters [the period of] Venus. There will be sudden gain of wealth and gains from strangers ${ }^{112}$ [or] from small ${ }^{113}$ objects if the [sub]period of Saturn enters [the period of] Venus. There will be attainment of dominion, gain of goods with little effort, and work will give [the desired] results when [the subperiod] of Jupiter [occurs] within the period of Venus. There will be discord with one's own people, wind in the stomach, painful illness and loss when [the subperiod of] Rāhu enters [the period of] Venus.

This concludes the results of Venus. Thus [the results of] the subperiods in the periods according to the school of [Bala]rāma are complete.

112 Or 'enemies'.

113 Or 'paltry'. 
athoktānāṃ daśākadambānāṃ viṣayavibhāgo nirūpyate granthāntare |

balì yadā hīnalavo grahah syāt tadā tu hīnāmśadaśā vidheyā| sarvagrahālokanalabdhavirye tanau tasīrākhyadaśā pradișțā $\mid$ lagnasya sabalatve hi bhāvapūrvā tu sā matā | kālahorādaśā kāryā savīrye 'bde ca tatpatau \|

haddākhyā varșalagnasya haddeśe balasaṃyute | abdacandre balopete kuryān naisargikīn daśām || saviryajanmarāssiśs muddā gaurìmatena tu| balasāmye tu sarveșām tasīrākhyā prakìrtitā \| savirye candrarāsisiśs balarāmāhvayā matā | sarve nabhogāh prekșante tanum bhāvadaśā tadā $\|$

tatra varṣe sarvāpekṣayā hīnāṃśagrahasya sabalatve hīnāṃśadaśā vidheyā | sarvagrahair dṛște lagne tasīradaśā | lagnasya sabalatve bhāvatasīradaśā | varșapraveśasamaye kālahoreśasya sabalatve kālahorādaśā | varṣapraveśalagnahaddeśvarasya sabalatve haddādaśā | candrasya sabalatve nisargadaśā | varṣe janmarāśiśvarasya sabalatve gaurīmatadaśā muddākhyā | varșe candrarāśsiśvarasya sabalatve balarāmamatadaśā vidheyā | sarveșāṃ balasāmye balāpekṣayā rahitā tasīradaśā kartavyā | lagnopari sarvagrahāṇāṃ dṛ̣ṭyabhāve bhāvadaśā kartavyeti tattvam ||

1 viṣaya] vișayā B N || nirūpyate] rūpyate $\mathrm{N} \quad$ 1-11 granthāntare ... tadā] om. B N G 2 hīnalavo] scripsi; hīnavalo K T; hīnabalo M 7 candre] scripsi; candra K T M $\|$ naisargikīṃ daśām] scripsi; naisargikī daśā K T M 11 nabhogāḥ] na bhogāḥ M || tanuṃ] scripsi; tanu K T M 12 grahasya] grahesya B N \| sabalatve] tadā add. K T M \| vidheyā] om. B N G 13 tasīra $^{1}$ ] nasāra B N || sabalatve] sarvavalatve B N G 15 sabalatve] bhāva add. B N G || sabalatve] balatve N; sarvalatve T 16 rāśíśvarasya] śaśíśvarasya B N 18-19 dṛștyaabhāve bhāva] dṛsțyābhāva B; dașțyāmāva N 19 tattvam] tatve B N

19 tattvam] Around this point, K T M add a table of durations of subperiods in the system of [Bala]rāma. Being absent from the earlier text witnesses, and containing only approximate values (rounded to the nearest integers), this table has been omitted. 


\subsection{The Use of the Different Systems of Periods}

Now, the respective scopes of the profusion of period [systems] described [above] are outlined in another book:

When the planet with the fewest degrees is strong, then periods according to reduced degrees should be used. If the ascendant gains strength by all planets aspecting it, the periods called tāsirra are prescribed. If the ascendant is strong, that [system] with [the phrase] 'of the houses' added is approved. The periods based on hours should be applied if the ruler of that [hour] is strong in the year, [and those] called [of the] haddā if the hadda ruler of the ascendant of the year is endowed with strength. If the moon in the year is possessed of strength, one should apply the natural periods. If the ruler of the sign [occupied by the moon] in the nativity is strong, the mudda according to the school of Gauri is prescribed; but if all are equal in strength, [the system] called tāsìra. If the ruler of the sign [occupied by] the moon [in the revolution of the year] is strong, [the system] named after Balarāma is approved; [and if] all planets aspect the first house, then the periods of the houses.

That is, if the planet with the least degrees of all is strong in the year, periods according to reduced degrees should be used; if the ascendant is aspected by all planets, tāsirra periods; if the ascendant is strong, tāsìra periods of the houses; if the ruler of the hour at the time of the revolution of the year is strong, the periods based on hours; if the ruler of the hadda on the ascendant of the revolution of the year is strong, the hadda periods; if the moon is strong, the natural periods; if the ruler of the sign [occupied by the moon] in the nativity is strong in the year, the periods according to the school of Gaurī, called mudda; if the ruler of the sign [occupied by] the moon in the year is strong, the periods according to the school of Balarāma should be used; if all are equal in strength, tāsira periods should be employed with no consideration of strength; and if no aspect of any planet is present in the ascendant, the periods of the houses should be employed:114 this is the truth of the matter.

114 It is not clear to which system this label refers. Additionally, Balabhadra appears to see a negation in the text which is not present there, perhaps reading (like text witness M) na bhogāh for nabho-gāh; but the latter word ('sky-goers') is formed from nabhas 'sky' and means 'planets'; bhogāh (meaning either 'pleasures' or 'coils') does not fit the context. 
atha daśāphale viśeșah | tatra pūrvaṃ pūrṇabalasya raver daśāphale gajāśvalābhādiphalam uktam | pūrṇabalaravidaśā tu sarveșām varṣapraveśe kadāpi na sambhavatīti nipāto na dṛśyate | parạ̣ tu teṣāṃ gajāśvalābhādikaṃ na dṛ́syate | tatra kiṃ kāraṇam iti ced ucyate | janmani jātakoktamārgeṇa raviś cet pūrṇabalo varṣe 'pi pūrṇabalạ śubhasthānagaś ca bhavati tadā gajāśvalābhādikam avaśyaṃ varșe vaktavyam | janmani hīnabale sūrye varșe pūrṇavīrye 'pi gajāśvalābhādikaṃ svapne bodhyam | uktạ̣ ca varāheṇa |

parịnamati phaloktị̣ svapnacintāsv avīryaiḥ || iti |

atha daśārișțam uktam hillājadīpikāyām |

daśādau daśeśas trirāssiśvaraś ca yadā naștaviryo bhaved riștam uktam | vipakșāșțamastho 'thavā krūradrșțo yutah syād ariștam tadā pākakāle || trirāsišsvarāc candrapākeśvarau tu ripucchidrarișpheșu saṃsthāv ariștam | trirāsiśsapākeśvarau siitaraśmer yadā vā tadādeśanīyam tv arișțam \| trirāsikeśas tanuto vidhor vā pākeśvarād dvidvimite dṛkāne | bhaved ariștam niyatam narānām anyonyam evaṃ vidușā prakalpyam \| janmalagnād daśāveśạ̣ șașthāșțastho daśeśvarāt | chidrāṃśasaṃstho vāriș̣tạ̣ karoti ripurāśigạ̣ ||

1 phale ${ }^{2}$ ] phalaṃ G 2 ravidaśā] na vidaśā B N 3 nipāto] pānitau N; niyamo G K T M 5 pūrṇal ${ }^{1}$ raviś cet pūrṇa add. $\mathrm{G}$ || varșe] varșo $\mathrm{B} N$ \| 'pi] vi $\mathrm{G} \quad 6$ tadā] rājā add. G || varșe] varșo B || janmani] janma M || hīna] hīne K T M 7 gajāśva] gajāśvādi K T M $\|$ svapne bodhyam] svam ebohyam $\mathrm{N}$ a.c.; svayam ebohyaṃ $\mathrm{N}$ p.c.; svapne vācyaṃ $\mathrm{G}$; svapne vaktavyam K T M 10 daśārișțam] daśānișțam B N 12 dṛșțo] dṛsța K T M 13 -iśvarāc] -iśvaraś K T M || saṃsthāv] saṃkhyāv K T M 14 arișțam] anișțaṃ B N 16 bhaved ... prakalpyam] scripsi; om. B N G K T M 17 șașțhāșțastho] ṣașțhāșțhemga G; șașṭhāṣțenge K T M || daśeśvarāt] deśeśvarāt G 18 saṃstho] sthotha K T M

9 parinamati ... avīryaih] BJ $8.22 \quad$ 11-882.6 daśādau ... prayāti] HD 10.1-7

16 bhaved ... prakalpyam] This half-stanza, syntactically required but omitted by all text witnesses, has been supplied from MS HD2, and the last word, partly obliterated by damage $\left(\right.$ praka* $\left.^{*}\right)$, emended. 
Next, a special consideration concerning the results of periods, as follows: in the results for the period of the sun with full strength, the results were stated above to be gain of elephants and horses and so on, ${ }^{115}$ and there is no exception to say that [these results of] the period of the sun with full strength are not always possible in everyone's annual revolution. All the same, there is no gain of elephants and horses and so on for those [persons]. If [it should be asked] what is the reason for this, [in reply] it is said: if, by the method described in the [Brhaj]jätaka, ${ }^{116}$ the sun is [found to be] of full strength in the nativity, and it has full strength in the year as well and occupies a good place, then gain of elephants and horses and so on is definitely to be predicted. [But] if the sun has little strength in the nativity but full strength in the year, gain of elephants and horses and so on should be understood [to occur only] in a dream. And [this] is stated by Varāha[mihira in Brihajjātaka 8.22]: 'The predicted results are transformed by powerless [planets] into [mere] dreams and fantasies.'

Next, unfortunate periods are described in Hillājadīpikā [11.1-7]:

When, at the beginning of a period, the ruler of the period and the triplicity ruler [of the ascendant?] have lost their strength, misfortune is declared; or if [both or either?] occupy the sixth or eighth house, aspected by or joined to malefics, there is misfortune during that period. [If] the moon and the ruler of the period are placed in the sixth, eighth or twelfth houses from the triplicity ruler, there is misfortune; or when the triplicity ruler and the ruler of the period [are so placed] from the moon, then too misfortune is to be predicted. [If] the triplicity ruler [is placed] in the twenty-second decan from the ascendant or the moon, [or] from the ruler of the period, men will certainly suffer misfortune. Thus the learned should consider [these planets] mutually.

[The ascendant at the time of] the commencement of the period occupying the sixth or eighth [sign] from the ascendant of the nativity, or occupying the degree of the eighth house from the ruler of the period, makes misfortune, [and likewise if] occupying the sixth sign.

115 In section 7·7.1.

116 Or, possibly: 'in [the science of] genethlialogy'. In either case, the appeal appears to be to pre-Islamic doctrines of nativities rather than to Tajjika sources, despite the fact that Balabhadra was acquainted at least to some extent with Samarasiṃha's surviving work on genethlialogy (the Karmaprakāśa), known to him as the Manusyajātaka (quoted in section 3.7 above). 
chidrāt trairāśipaḥ śodhyạ̣ saśanir mrtyusadmakam |

tatkāle vīryasaṃyuktam ariștam jāyate dhruvam \|

tatkāle viryahinaś ca vilagnādhipatiryadā |

vyayāricchidragaś cet syāt tadāriștam prajāyate \|

daśādhipo viryayutah praveśe trairāśikeśo 'pi yutah śubhaiś ca |

drșțas trikonopacayasthitaś cet tadāśu riștam vilayam prayāti $\|$

iti śrīmaddaivajñavaryapaṇ̣itadāmodarātmajabalabhadraviracite hāyanaratne daśānayanādhikārạ̣ saptamaḥ $\|7\|$

1 sadmakam] saṃdhakaṃ B N $\quad 2$ arișțam ] anișțam B N 3 tatkāle] tattatkāle B; tatatkāle N || hīnaś ca] hī G a.c.; hīna G p.c. 6 dṛșțas] ișțas B N; dṛțțis K T M $\quad$ 7-8 iti ... saptamah] śrībalabhadrakṛte hāyanaratne daśānayanādhikārādhyāyaḥ K T M 7 śrīmad] śrībhațta B || varya] varșa B || paṇḍita] ghațita B N 8 saptamaḥ] samāpta B; samāptạ̣ N 
The triplicity ruler subtracted from the eighth house and added to Saturn is the lot of death. ${ }^{117}$ [If it is] endowed with strength at that time, ${ }^{118}$ misfortune certainly arises. And if the ruler of the ascendant should be bereft of strength at that time, occupying the twelfth, sixth or eighth house, then misfortune arises. [But] if the ruler of the period is endowed with strength at the commencement [of the period], and the triplicity ruler, too, joined or aspected by benefics and occupying a trine or a place of increase, then the misfortune swiftly abates.

In the Hāyanaratna composed by Balabhadra, son of the illustrious learned Dāmodara, foremost of astrologers, this concludes the seventh topic: calculating the periods.

117 The standard calculation of this lot, as seen in section 4.3 above, involves the moon rather than the triplicity ruler (of the ascendant?).

118 Presumably the time of commencement of a period. 